\title{
QUESTÃO DE ORDEM \\ O CONCEITO DE "FORMA" COMO FERRAMENTA PARA O PROCESSO CRIATIVO DO ATOR
}

Dissertação apresentada ao Programa de PósGraduação em Artes Cênicas, Área de Concentração Pedagogia do Teatro, Linha de Pesquisa Formação do Artista Teatral, da Escola de Comunicações e Artes da Universidade de São Paulo, como exigência parcial para obtenção do Título de Mestre em Artes, sob a orientação do Prof. Dr. Antonio Luiz Dias Januzelli.

São Paulo

2008 


\section{QUESTÃO DE ORDEM}

O CONCEITO DE "FORMA" COMO FERRAMENTA PARA O PROCESSO CRIATIVO DO ATOR 
Àqueles que eи amo, pelo apoio e paciência durante a construção deste trabalho. 
Ao professor Januzelli, pela chance de aprendizado e pelos preciosos ensinamentos.

Ao professor Armando, pelo incentivo e orientações que impulsionaram a elaboração deste trabalho.

À professora Mariela, pela inestimável contribuição que deu à minha formação e pelo carinho com que sempre me recebeu e orientou.

A Rosângela, que tanto me ajudou na realização desta dissertação estimulando, comentando, corrigindo e refletindo essa vivência que é nossa.

Aos parceiros do grupo de pesquisa: Ana Carolina, Camila, Cândida, Débora, Flávia, Laura, Kevin e Rejane, pelas dicas, reflexões, exemplos e cumplicidade.

Aos amigos e companheiros de experimentações, Renata e Zé Raimundo, sem os quais seria difícil caminhar.

A Edney, por estar sempre ao meu lado. 
“Quando se começa a pintar, muitas vezes surgem efeitos bonitos. Mas, cuidado! Destrua a imagem; recrie-a várias vezes. Cada vez que o artista destrói uma descoberta, na verdade, ele não a suprime, mas, antes, a transforma, a condensa, tornando-a mais substancial. O que no final resultará é produto de descobertas rejeitadas." 
"Então que estranha necessidade é esta, de precisar encontrar uma medida de ordem - como intima razão de ser - e expressá-la em termos estéticos!" 
Esta pesquisa tem o propósito de verificar na prática o modo como os conceitos de Fayga Ostrower relativos ao processo de criação podem contribuir para a construção da obra cênica. Para essa finalidade é feito, nas páginas que se seguem o relato da elaboração de uma cena ao longo do ano de 2007 dentro da Universidade de São Paulo no Centro de Pesquisa em Experimentação Cênica do Ator, coordenado pelo professor livre docente Armando Sérgio da Silva.

No primeiro capítulo é feita a apresentação do conceito de "forma" como é entendido por Fayga, bem como as bases do pensamento criativo por ela propostas. $\mathrm{Na}$ segunda parte estão expostos os princípios norteadores do caminho percorrido e a abordagem feita dos estímulos selecionados. O último capítulo traz uma descrição detalhada dos resultados alcançados e as seguidas transformações que a cena foi sofrendo até chegar na sua versão final.

PALAVRAS-CHAVE: ARTE,PROCESSO, CRIAÇÃO, FORMA, TEATRO, ATOR. 
The present research intends to verify in practice how the concepts of Fayga Ostrower relating to creating process can contribute to the construction of the scenic work. For this purpose is done, in the following pages, our story about the development of a scene during 2007 at University of São Paulo in the Research Center in Actor's Scenic Trial, coordinated by Professor Armando Sergio da Silva.

In the first chapter we have the "form" concept, as it is understood by Fayga, and the foundations of creative thinking are proposed. In the second part are exposed the guiding principles of the path and our approach made on selected stimuli. The last chapter provides a detailed description on achieved results and changes suffered by the scene until its final version.

KEY-WORDS: ART, CREATING PROCESS, FORM, THEATER, ACTOR. 
INTRODUÇÃO

I - BASES TEÓRICAS

1. ARTES PLÁSTICAS COMO ASCENDÊNCIA

A necessidade de criar 23

A forma de Fayga $\quad 24$

"Forma" enquanto resultado de uma ordenação 25

2. REFERENCIAIS PARA A CRIAÇÃO

Memória 28

Percepção $\quad 29$

Intuição 31

Acasos $\quad 31$

Associações $\quad 32$

Liberdade X Limitação $\quad 34$

Linguagem e conteúdos $\quad 36$

3. A PONTE 37

II - FALANDO DA PRÁTICA

1. OS PRIMEIROS PASSOS

O ponto de partida $\quad 40$

Hamlet $\quad 42$

Os anteparos criativos $\quad 48$

$\begin{array}{ll}\text { A parceria } & 58\end{array}$

Traçando novos objetivos $\quad 61$

2. OS INSTRUMENTOS DE TRABALHO
A necessidade de aquecer

$\begin{array}{ll}O & \text { contato improvisação } \\ & 66\end{array}$

A composição $\quad 69$

II - OS MECANISMOS DE CRIAÇÃO 72

1. ROTINA DE TRABALHO 73

$\begin{array}{ll}\text { A voz } & 76\end{array}$

$\begin{array}{ll}\text { O corpo no espaço } & 78\end{array}$

2. A ANSIEDADE PELA FINALIZAÇÃO 83

3. O PONTO DE MUTAÇÃO 86

4. A RETA FINAL $\quad 89$ 
ANEXOS entrelinhas, as dúvidas que são as grandes responsáveis pelas minhas ações. "I

Criar é uma necessidade humana e é na arte que o homem reconhece mais claramente a concretização dessa ação. Nos vários ambientes onde se costuma falar de criatividade é comum a convicção de que a ação de criar, pelos procedimentos que a envolvem, nos ajuda a entender e a reformular a realidade que nos cerca. Esta é uma questão de extrema importância para o ser humano em geral porque compreender e transitar com tranqüilidade por uma dada circunstância é a melhor maneira de sentir-se segura a seu respeito. Eis, portanto, a razão de

\footnotetext{
${ }^{1}$ Armando Sergio da Silva - Oficina da Essência - p. 03.
} 
consideramos a prática criativa um mecanismo fundamental: o equilíbrio que atingimos quando empreendemos ações dessa natureza.

Entre as pessoas que não possuem formação especializada em artes a vontade de se expressar através de linguagens artísticas existe quase sempre. Entre aqueles que escolheram serem artistas enquanto meio de vida, sempre existem os que, durante o período de formação, precisam de mais orientação e dedicação por parte de seus mestres para que encontrem os caminhos que lhes permitirão atender a esse anseio de se expressar na sua forma pessoal com autonomia. Como professora de artes da rede municipal de ensino básico, tenho interesse em estudar procedimentos que facilitem o aprendizado de uns e outros.

Nosso sonho enquanto educadores é conduzir nossos alunos por um processo tal que dê a eles a capacidade de experimentar com liberdade, levantar e testar hipóteses, chegar a conclusões, transformar elementos e reorganizar informações fazendo surgir novas formas e conceitos, apropriar-se e produzir conhecimento. Acreditamos que a arte é o mais abrangente e marcante meio para esse crescimento. Contudo, ensinar arte através da plástica, base da minha formação acadêmica, em escolas públicas na periferia que não tinham condições de fornecer nenhum tipo de material para seus alunos era uma tarefa difícil. Transmitir os conceitos da arte através do teatro, que precisa somente de um espaço escolhido para acontecer, revelou-se o caminho mais fácil a seguir. Foi por essa estrada chegamos ao teatro: sensibilizando alunos para a arte através da prática teatral.

Fayga Ostrower ${ }^{2}$ possuía uma maneira de ver o pensamento criativo essencialmente como um mecanismo de ordenação, o que torna o seu aprendizado acessível a todos, pois ordenar é uma habilidade inerente ao ser humano. Em sua análise da criatividade, Fayga atribui ao repertório pessoal e à experimentação do material escolhido para a composição da obra a maior parte da responsabilidade pelos resultados obtidos na sua finalização. Ela defende a idéia de que criar é organizar elementos de modo coerente dentro de padrões estabelecidos pela cultura, pela matéria e pela memória. Com isso aproxima o homem comum do artista iluminado, deixando a ambos a tarefa de, através de escolhas conscientes, dar forma a uma idéia surgida da relação que se estabelece entre criador, repertório e matéria prima. Fayga afirma não ser possível ensinar alguém a fazer arte por ser uma ação relacionada a particularidades de ordenação e de vivência absolutamente pessoais. Segundo ela o que se

\footnotetext{
${ }^{2}$ Fayga Ostrower - artista plástica, professora e teórica da Arte.
} 
pode de fato fazer é educar a sensibilidade e fortalecer o entendimento do envolvimento da consciência no processo criativo.

A cena desenvolvida como objeto de estudo para esta dissertação surgiu dentro da proposta de trabalho do Centro de Pesquisa em Experimentação Cênica do Ator coordenado pelo professor Doutor Armando Sérgio da Silva. ${ }^{3} \mathrm{O}$ grupo de participantes formou-se devido à vontade que manifestaram alunos e professor em dar continuidade ao trabalho desenvolvido em duas disciplinas da Pós-graduação - Exercícios específicos para o ator I e II - ministradas em 2006 pelo professor Armando. Nessas disciplinas alunos mestrandos, doutorandos, especiais e ouvintes traziam semanalmente resultados cênicos obtidos através de seus procedimentos particulares de criação. O objetivo do grupo era estruturar cenas onde ficassem evidentes os caminhos percorridos e as peculiaridades de cada artista na sua maneira própria de criar. Para tanto ficou estabelecido que semanalmente, e segundo um cronograma pré-estabelecido, um número determinado de alunos apresentaria seus resultados para apreciação do grupo que tinha a missão de auxiliar cada membro com comentários, críticas e apontamento de potencialidades.

A ligação entre os membros do grupo fortaleceu-se ao longo do ano de trabalho, instalando-se um clima de intensa produtividade artística onde se destacou a profunda admiração e respeito pelas diferenças. As contribuições vinham através de críticas sempre construtivas e fundamentadas em verificar a comunicabilidade e a coerência das cenas dentro do percurso a que elas se propunham. Sem que se pusesse em questão tópicos referentes a gosto pessoal, todos contribuíam com seu modo particular de perceber o trabalho do outro.

No primeiro semestre de 2006 foi proposta pelo professor Armando a temática América Latina como diretriz das cenas a serem desenvolvidas. Cada participante da disciplina deveria preocupar-se em demonstrar os procedimentos de que se utilizava enquanto ator. Naquela ocasião foi apresentada uma cena com um grupo de ex-alunas da escola onde surgiu a primeira semente desta pesquisa. Trabalhamos com base nos textos de Jorge Amado, imagens de Carybé e exercícios que utilizávamos com os alunos dos grupos extra-classe de teatro que coordenamos lá durante sete anos. Já no segundo semestre foi solicitado que utilizássemos histórias infantis como estímulo para traçarmos um perfil da violência na cidade grande. Para esta fase colegas que possuíam suas próprias pesquisas ou colaboravam

\footnotetext{
${ }^{3}$ Armando Sérgio da Silva é professor livre-docente do Departamento de Artes Cênicas da ECA-USP.
} 
com alguma, se propuseram a executar o que seria uma primeira versão deste projeto. Trabalhamos partindo do conto tradicional europeu Sapatos vermelhos, textos apócrifos da Bíblia, pinturas impressionistas e esculturas de Rodin. Ao final do ano juntamos todas as cenas do $2^{\circ}$ semestre num espetáculo intitulado Um ônibus chamado S.P. - Sem Pudor.

Ainda que o $2^{\circ}$ semestre tenha representado um grande amadurecimento dentro dos procedimentos adotados pelo grupo de pesquisa, o resultado final resultou bastante fragmentado na nossa opinião posterior, não como proposta estética, mas como necessidade funcional da união de abordagens tão diversas entre si e que foram construídas a partir de narrativas diferentes. Foi uma grande dificuldade integrar todos. Mas o caminho percorrido foi tão absolutamente apaixonante que o grupo decidiu manter-se unido e dar continuidade a essa dinâmica de pesquisa. Para um resultado mais satisfatório neste aspecto, buscávamos em 2007 uma maior unidade, sem sacrificar o vigor de cada individualidade.

No ano de 2007 escolheu-se o texto Hamlet de Shakespeare como estímulo básico, e ficou decidido que iríamos ainda mais fundo nas pesquisas pessoais e na explicitação do processo criativo que cada um estava vivenciando. ${ }^{4}$ Essa abordagem foi de importância capital para o desenvolvimento desta dissertação pois deu-nos a oportunidade de delinear nossos próprios procedimentos de criação com mais precisão, novamente com o suporte do grupo. Para concretizar a pesquisa foi formada uma parceria com a atriz Renata Vendramin que, com imensa generosidade, e pela segunda vez, se propôs a estudar comigo o pensamento de Fayga Ostrower acerca do processo criativo em artes plásticas e testar a sua aplicabilidade na criação para a cena. $\mathrm{O}$ entendimento do elo existente entre os conceitos propostos por Fayga e os procedimentos de criação teatral concretizou-se graças à parceria com Renata e aos preciosos comentários do grupo de pesquisa.

Foi com grande alegria que observamos serem os pensamentos de Fayga e Armando Sérgio bastante semelhantes, o que era de se esperar pois ambos buscavam caminhos para ensinar arte e acreditavam que os artistas retiram deles mesmos o material para a sua produção, que não lhes é fornecido pelo Espírito Santo como um favor pessoal, e nem deve ser determinado por mestres de qualquer natureza.

\footnotetext{
${ }^{4}$ Nosso grupo contava, por ocasião da finalização do processo de 2007, com onze participantes que concluíram cenas e dois que acompanharam todo o trabalho, mas não puderam finalizar conosco, totalizando treze integrantes.
} 
"O desafio do processo pedagógico é ensinar através da ausência."

O professor Armando aponta em seu livro alguns procedimentos metodológicos que aplica nas aulas com o intuito de ensinar ao aluno-ator formas de libertar sua criatividade, tornando-o independente e auto-suficiente no que concerne aos caminhos de criação na sua arte. Esses mesmos pensamentos orientavam seus procedimentos no grupo de pesquisa. Por acreditar que o aluno é o agente que constrói ativamente conhecimentos e competências, o professor trouxe para o grupo a proposta de sermos um coletivo de individualidades fortes. Armando afirma que toda competência e conhecimento que o ator necessita para a elaboração da sua cena é construído a partir de vivências, sensações e pensamentos anteriores, portanto únicos e verdadeiros. Essas vivências podem ser de qualquer natureza, e não necessariamente dramática, para serem aproveitadas num treinamento e construção de cena. Estes pontos em comum com o pensamento de Fayga nos encorajaram a tomar parte neste projeto. Sentindonos bastante confiantes, demos início à jornada.

Este trabalho se propõe a relatar o processo de criação desenvolvido e apresentado dentro do grupo de pesquisa ao longo de 2007, descrever os princípios oriundos das artes plásticas que nortearam o trabalho e verificar em que medida esse diálogo foi benéfico para os resultados da cena.

É claro que os frutos colhidos e aqui descritos não foram semeados no ano do desenvolvimento desta pesquisa. Aventuramo-nos no teatro com certa continuidade desde 1992. Sempre atuando em escolas do ensino público regular e testando nossos limitados conhecimentos cênicos adquiridos no curso de licenciatura em educação artística pela Fundação Armando Álvares Penteado (FAAP) em salas de aula de até 50 alunos ou em grupos extra-classe que variaram dos mesmos 50 até 9 participantes. Trabalhamos com textos dramáticos, romances, poesias, filmes, notícias de jornal, programas humorísticos e letras de música, experimentando formatos diversos em tentativas de adequar a prática teatral às aulas de artes para ensino fundamental e médio. Passamos por várias escolas e obtivemos resultados que foram muito encorajadores.

\footnotetext{
${ }^{5}$ Armando Sergio da Silva - Oficina da Essência - p. 06
} 
No período de 1994 a 2003, na E.E. Prof ${ }^{a}$ Maria Augusta de Ávila, uma série de condições favoráveis levou à criação e desenvolvimento de um projeto educacional que fazia do teatro o caminho para tratar de questões pedagógicas, disciplinares, sociais e de autoestima dos alunos. Paralelamente ao trabalho com os alunos fora do horário de aula, começamos a realizar laboratórios em sala de forma mais sistemática. Dentre os vários grupos que apresentavam montagens para a disciplina de artes, alguns manifestavam interesse em apresentar suas peças para a escola, dando força a um festival de teatro que começou como uma das atividades da feira cultural e científica que já era tradição dentro da unidade escolar. A quantidade de alunos que participavam do festival interno e queriam intensificar suas experiências cênicas foi crescendo de forma espetacular e acabou dando origem a outros dois grupos teatrais, além de estabelecer uma equipe de professores que passou a coordenar o projeto teatral da escola. Houve um ano em que contávamos com os três grupos teatrais com uma média de 25 alunos cada produzindo a todo vapor, além de um festival que contou na ocasião com a participação de 30 grupos de idades diversas com cerca de 15 integrantes cada. Era uma grande festa!

Os grupos oficiais da escola estavam então divididos da seguinte maneira:

- Tal \& Pá - trabalhando com ensino médio.

- Tal \& Pá Jr - iniciado em 1999 para atender ao ensino fundamental e hoje sob o comando de alunos mais antigos oriundos do grupo principal.

- Uni Duni Tê - também para alunos do ensino médio, atualmente sob a direção da atriz e diretora Patrícia Nepomuceno e já desvinculado da escola onde iniciou suas atividades. (ilustração 1 )

O que começou com certa informalidade foi despertando na equipe de coordenação do projeto $^{6}$ a vontade de aprofundamento dos conhecimentos específicos do teatro e as possibilidades de conexão com os questionamentos particulares de cada membro quanto ao trabalho pedagógico, relações entre cultura e sociedade bem como elementos da pesquisa e expressão artística. Assim, fomos buscando informação e orientação nas mais variadas fontes:

\footnotetext{
${ }^{6}$ Que consistia na ocasião de um grupo de quatro professores das disciplinas de artes, português, história e biologia em caráter permanente, contando com a ajuda ocasional de 12 outros colegas.
} 
livros, espetáculos, cursos e debates de toda a natureza e trazendo nosso aprendizado para os grupos que se formaram com a intenção de realizar montagens anuais.

Os grupos extra-classe eram os grandes estimuladores da produção teatral na escola além de laboratórios para nossa experimentação. O trabalho realizado por esses grupos esteve durante muitos anos baseado nos jogos teatrais de Viola Spolin, mas hoje percebemos que outras influências se faziam presentes e não eram reconhecidas até então. Aqui faz-se necessário um retorno à uma fase anterior.

O primeiro contato com Spolin deu-se na graduação, em um semestre de introdução ao teatro, onde a professora Heloísa Sales apresentou de forma prática o conceito de foco e os elementos básicos da narrativa dentro da prática teatral no formato de jogo com regras a serem observadas como é sugerido por Viola.

Jogar é sempre um prazer. Trabalhar livremente dentro de regras estabelecidas e observar se o outro, enquanto jogador, manteve-se ou não fiel ao combinado, elimina o conceito de "talento"7, além de fortalecer os laços entre os jogadores que precisam estar atentos entre si e se ajudarem a solucionar problemas. Na terra do futebol isso e um prato cheio e mantinha toda uma turma de graduação noturna em artes plásticas ansiosa pelas aulas de teatro que aconteciam às sextas feiras, indício revelador do interesse e envolvimento alcançados pela disciplina.

Essa experiência foi a base das primeiras tentativas dramáticas, dentro e fora da sala de aula, sendo recuperada e adaptada ao universo estudantil no qual estávamos inseridos no momento de maior intensidade da produção cênica naquela escola mencionada anteriormente. Até então, não havíamos estudado a proposta de Viola em profundidade. Nem tampouco tivemos orientações que permitissem uma análise mais acertada e uma reflexão aprofundada do pensamento de Spolin. Nossos procedimentos, na graduação e posteriormente no transcorrer das aulas, apoiavam-se exclusivamente no nosso próprio entendimento das idéias da autora.

\footnotetext{
${ }^{7}$ A noção de "talento" é, em muitas situações, extremamente nociva e inibidora do aprendizado para a cena e através dela.
} 
Após alguns anos de parceria incompleta com Spolin, a equipe de orientadores foi apresentada a Stanislavski e isso trouxe novidades para ao trabalho na escola. $O$ desenvolvimento dos alunos/atores passou a ser abordado sob o enfoque do entendimento do texto segundo a compreensão que tínhamos de conceitos como as seqüências de ações, subtextos e memória emotiva. Não que dominássemos as idéias de Stanislavski a ponto de organizar o percurso de forma sólida. Éramos movidos pelo entusiasmo e por nossos olhos de espectadores que buscavam resultados convincentes.

A falta de bagagem teórica e prática real sobre o fazer teatral não nos impediu de termos iniciativas nessa área, por vezes bastante arrojadas. Muitas das opções cênicas que fizemos foram até mesmo consideravelmente satisfatórias. Mas não se chegou a elas com base no domínio da linguagem teatral. O que quase sempre ocorreu foram organizações instintivamente funcionais que trouxeram bons resultados. Outras vezes entravam em ação conceitos da plástica e através deles tateava-se o palco em busca de soluções. No entanto, raramente executamos transposições das artes visuais para a cena - de qualquer maneira as melhores configurações não foram alcançadas por este caminho. O que via de regra acontecia era a utilização de estruturas fundamentais do fazer artístico reconhecíveis na visualidade e que eram adaptados para os elementos que compunham o fazer sobre o palco, tanto com relação à interpretação quanto à encenação como um todo.

Talvez devido ao grande número de alunos existentes em cada grupo (sempre entre 30 e 50 membros), ou pelo pouco tempo disponível para a elaboração das montagens (cerca de 4 horas semanais, nem sempre contínuas), ou ainda pela própria falta de formação dos coordenadores; o fato é que nosso trabalho na escola era baseado em movimentação soluções de encenação se sobrepondo ao trabalho de interpretação quase como num trabalho coreográfico onde se buscava uma harmonia na movimentação, nas alturas, no uso do espaço e no equilíbrio das formas. Talvez uma breve experiência com ballet (aos 10 anos) tenha certa responsabilidade por esse caráter eminentemente visual do trabalho.

A formação em plástica torna mais fácil entender e falar através do que se pode tornar visível. A evolução dessa habilidade deve ser creditada Mariela Mielzynska Kantor $^{8}-$ com $^{2}$ quem trabalhamos de 1995 a 1998 como pesquisadora. Através dela estabelecia-se uma relação confiante e tranqüila com as artes plásticas, o que acabou resultando posteriormente

\footnotetext{
${ }_{8}^{8}$ Professora de História da Arte na graduação e pós-graduação da Fundação Armando Álvares Penteado (FAAP).
} 
num modo muito particular de trabalhar com o teatro. Durante a graduação conhecemos também o pensamento de Fayga Ostrower, artista plástica que publicou suas reflexões sobre o processo criativo e que muito auxiliaram pensar o fazer artístico como um todo e sobre a prática aqui descrita em particular.

Foi somente em 2002 que surgiu a oportunidade de acompanhar o trabalho de formação de jovens artistas desenvolvido pelo professor Antonio Luiz Dias Januzelli, o Janô, ${ }^{9}$ quando vislumbramos, ainda com alguma insegurança, os princípios comuns que viabilizavam a aproximação da prática teatral pela via das artes plásticas. Na sua busca pela essência do trabalho do ator o professor Janô levantou questões que permitiram a estruturação das primeiras reflexões realmente conscientes acerca dos procedimentos que vinham sendo utilizados e trouxe o discernimento de algumas especificidades das artes cênicas. Entendemos a importância, por exemplo, de diferenciar o trabalho de preparação do ator daquele que trata do seu processo de criação. Essas duas faces da prática teatral não são estanques e incomunicáveis, mas estão profundamente ligadas e por vezes atuam simultaneamente.

Durante os procedimentos de preparo do ator para o exercício do seu ofício ele é apresentado a uma série de técnicas e conceitos destinados à sensibilização e ampliação dos recursos do seu "instrumento" (corpo e voz) e das suas habilidades em se relacionar consigo mesmo, com o parceiro, a platéia, os objetos de que se utiliza na cena e dentro do espaço. É um trabalho de afinação que deve continuar ao longo de toda a vida do artista para mantê-lo limpo de tensões e influências improdutivas, deixando-o sempre pronto para a ação. $\mathrm{O}$ material originado nesses momentos pode ser utilizado na formalização de uma obra cênica, ainda que não possua essa intenção em primeira instância.

Os procedimentos que envolvem a criação estão ligados à fase inicial de treinamento do artista, mas utilizam os recursos e resultados dessa fase inicial como partes integrantes de um objeto que está sendo construído. O processo de criação ocupa-se de todo o material que dele faz parte enquanto componente de linguagem. O trabalho criativo envolve ações que tencionam chegar a uma finalização e incluem o ator como integrante de uma obra que se pretende completa.

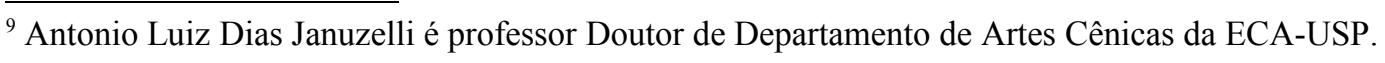


Tendo percorrido todo este caminho, algumas perguntas de professora e aprendiz foram sendo formuladas e conduziram a este momento:

Que etapas devem ser percorridas por quem deseja fazer uso da arte como veículo para que ele se aproprie da sua própria capacidade expressiva, comunicativa, analítica e reflexiva?

Como instrumentar essa pessoa para que se reconheça capaz de acessar seu próprio repertório e conscientemente renová-lo sempre que assim o quiser?

Como treiná-la para que adquira autonomia em relação ao conhecimento a ela apresentado e estenda essa habilidade a outros aspectos da sua vida?

Quais elementos da linguagem da arte, e mais especificamente do teatro, precisam ser efetivamente dominados para que o seu desempenho enquanto produtora possua verdade e consistência?

É possível resolver problemas de interpretação a partir do diálogo com outras formas expressivas?

São essas perguntas que têm motivado as ações que culminaram no processo aqui relatado. Das dúvidas impressas nestas questões nasceu a necessidade de experimentar e formalizar uma maneira de perguntar e responder através da arte. Com isso, conhecimentos que foram transmitidos por todos esses mestres, que muito oportunamente abriram nossos olhos para as qualidades que carregamos, foram progressivamente sendo recuperados. Este trabalho é, portanto, uma oportunidade de clarear as idéias e refletir sobre nossos caminhos nas artes plásticas, na educação e no teatro. 
I.

BASES TEÓRICAS 
1.

\section{ARTES PLÁSTICAS COMO ASCENDÊNCIA}

\section{A NECESSIDADE DE CRIAR}

"Nas múltiplas formas em que o homem age e onde penetra seu pensamento, nas artes, nas ciências, na tecnologia, ou no cotidiano, em todos os comportamentos produtivos e atuantes do homem verifica-se a origem comum dos processos criativos numa só sensibilidade. São análogos os princípios ordenadores que regem o fazer e o pensar. Na avaliação de resultados, em qualquer área, partimos de noções similares de desenvolvimento e de equilíbrio. ",10

Quando criamos através da arte, procuramos modos de organização estética. Mas não se cria apenas artisticamente. Pensando num sentido mais abrangente, criar é um caminho para a resolução de um problema qualquer que esteja ligado à satisfação de uma necessidade

\footnotetext{
${ }^{10}$ Fayga Ostrower $-\underline{\text { Criatividade e processos de criação }}-$ p. 31.
} 
classificada como prioritária em dado momento e que não possui uma saída satisfatória já estabelecida. Adequar-se a um aspecto da sociedade, encontrar soluções técnicas para o manuseio de determinado material visando um efeito específico, ampliar a produtividade, encontrar o ritmo perfeito numa seqüência de palavras para uma poesia, combater um vírus ou solucionar dificuldades de aprendizagem de uma criança são obstáculos que exigem soluções construídas ou adaptadas para cada uma dessas situações da forma como elas se apresentarem. É neste momento em que a necessidade nos impele a agir que entramos num "processo criativo".

Se tentarmos classificar as etapas da criação de forma genérica poderemos iniciar observando que ela é impulsionada pela total absorção do indivíduo por uma problemática a ser solucionada. A tal ponto esse problema será instigante que mobilizará do criador a energia e os referenciais de conhecimento prévios necessários para a formação de uma nova realidade. Então, em algum instante que normalmente não sabemos precisar, parece surgir uma idéia decisiva que traz a luz de um caminho praticável. Logo em seguida ocorrerá o empenho em experimentar a inspiração que parece "ter surgido do nada", elaborando demonstrações e verificando os resultados que vão sendo alcançados. Nesta análise podemos perceber que a ação criadora traz em si uma grande dose de vontade consciente. $O$ ato criador não pode existir como tal desvinculado da intenção de concretizá-lo porque exige a apropriação de qualidades, a avaliação de quais conhecimentos seriam mais convenientemente utilizados na resolução da questão e a clareza de objetivos na experimentação das alternativas descobertas.

Olhando a produção criativa sob este enfoque de etapas e procedimentos, podemos imaginar que ela se refere menos a súbitas "explosões de luz provenientes da graça divina" e muito mais a abordagens atentas sobre materialidades - definindo-se matéria enquanto tema de trabalho, seja ele de ordem física ou intelectual. Todas essas reflexões são apresentadas pela voz de Fayga Ostrower, artista que, refletindo sobre o seu próprio fazer artístico e observando grandes mestres do passado, elaborou uma maneira de ver e pensar o processo criativo que viriam a se desdobrar em novos e apaixonantes caminhos. 
"A realização das potencialidades criativas de uma pessoa envolve, portanto, um caminho de vida, cujas etapas não podem ser queimadas; ela têm que ser vividas. " ${ }^{11}$

Nascida em Lodz, na Polônia, em 1920, Fayga Ostrower chegou ao Brasil na década de 30, instalando-se no Rio de Janeiro, vindo a falecer nessa mesma cidade em 2001. Freqüentou o curso de artes gráficas da Fundação Getúlio Vargas em 1947, onde teve particular interesse pelas aulas de xilogravura e gravura em metal. Realizou exposições individuais e coletivas dentro e fora do Brasil, tendo trabalhos seus expostos em grandes museus da Europa e da América. Foi premiada nas Bienais de São Paulo (1957), Veneza (1958) e Florença, Buenos Aires, México e Venezuela nos anos subseqüentes.

Lecionou no Museu de Arte Moderna do Rio de Janeiro, no Spellman College em Atlanta, na Slade School da Universidade de Londres e foi professora na pós-graduação de várias universidades brasileiras. Foi palestrante e divulgadora da arte em centros comunitários e instituições culturais.

Trabalhou em associações de naturezas diversas como a comissão brasileira da International Society of Education throug Art da Unesco, a Associação Brasileira de Artes Plásticas, o Conselho Estadual da Cultura do Rio de Janeiro, a Academia de Arte e Desenho de Florença (como membro honorário). Recebeu prêmios e condecorações diversas.

Dentre os vários livros que publicou aqueles que analisaram o processo criativo foram referência no curso de Licenciatura em Educação Artística com habilitação em Artes Plásticas da FAAP, sendo, conseqüentemente, a base conceitual que determinou os rumos desta pesquisa. Ao longo dos anos onde a prática aqui apresentada foi delineada, as idéias de Fayga foram sendo absorvidas e sua abrangência nos levou a experimentá-las fora do universo das artes plásticas, onde se originaram. Fayga elabora sua análise da criatividade considerando que o pensamento criativo trabalha num sistema baseado no conceito de "forma" segundo o qual ela afirma que criar é dar ordem a elementos selecionados pelo artista através da percepção de relações existentes entre a materialidade escolhida como veículo e o seu

\footnotetext{
${ }^{11}$ Fayga Ostrower - $\underline{\text { Acasos e criação artística }}-$ p.218.
} 
repertório pessoal, que abarca questões referentes à cultura em que se está inserido e à sua memória de experiências vividas.

\section{FORMA}

ENQUANTO RESULTADO DE UMA ORDENAÇÃO

"A forma converte a expressão subjetiva em comunicação objetivada."

Entendemos por forma a configuração dos elementos constituintes de um objeto enquanto determinantes dos seus limites externos que o separam do espaço circundante. A forma é, portanto, geralmente associada ao contorno da matéria, mas não se restringe a ele uma vez que a linha limítrofe percebida é sempre resultante das especificidades internas do elemento observado. Tomemos como exemplo uma cadeira e uma mesa. É a maneira pela qual estão construídas e se relacionam as partes de ambas que nos permite reconhecê-las como diferentes entre si. Para diferenciá-las levamos em conta informações variadas como o material de que são feitas, suas dimensões, qualidades lineares ou cores. No entanto, mesmo numa situação em que esses elementos sejam similares, a ordem presente nos relacionamentos que ocorrerem entre essas qualidades permitirá a separação desses corpos como objetos desiguais. Podemos admitir então que a forma é um dos parâmetros pelos quais somos capazes de discernir e classificar, ações básicas da formação dos conceitos.

O ser humano necessita da idéia de forma para transitar com mais propriedade pelos diversos campos em que pode agir porque o homem é um ser organizador por excelência. Construímos nosso conhecimento do mundo a partir de comparações entre estruturas que já nos são familiares - que correspondem a uma complexa rede de valores, emoções, e dados diversos interligados e constituintes da natureza do fenômenos - e novas circunstâncias que desconhecemos. Quando uma criança nasce, por exemplo, começa imediatamente a estabelecer relações dentro de ordenações específicas. Se ela sente algum desconforto, chora, recebe o atendimento necessário e a sensação de bem-estar vem. Essa seqüência é fixada

\footnotetext{
${ }^{12}$ Fayga Ostrower - Criatividade e processos de criação - p. 24.
} 
como uma vivência que servirá de parâmetro para as posteriores. Em breve ela relacionará determinados sons, cheiros e objetos, que passarão a ter um significado de acordo com a ordem em que surgem e não somente pela suas características individuais. Dentro do seu ainda limitado universo, cada ordenação significativa possui poucos elementos combinandose em seqüências variáveis que vão se adequando às diversas situações. Portanto, a ordem é fator importante no estabelecimento do sentido e este é um princípio determinante do conceito de forma.

Por tratar-se de uma questão de ordem, a generalidade da idéia de forma lhe confere o direito de aplicar-se a campos que não necessariamente tratam da visualidade. É o que ocorre na química, por exemplo. Basta nos lembrarmos que também é através de formações definidas que analisamos e compreendemos as substâncias, que se definem de acordo com a maneira como se ordenam os elementos químicos que fazem parte das suas composições. Se analisarmos um conceito ou definição de qualquer natureza verificaremos que estamos tratando sempre de informações organizadas de um modo específico. As idéias se conectam numa ordenação própria e nela assumem seu significado. $\mathrm{O}$ mesmo se dá com a disposição das palavras que transmitem os conceitos abstratos: dentro de cada estrutura formal em que se apresentam elas assumem sentidos diversos.

"A forma será sempre compreendida como a estrutura de relações, como o modo por que as relações se ordenam e se configuram. Teremos a forma de uma mesa, mas também teremos a forma de uma ação, de uma teoria, de determinada situação, de determinado caráter, ou de outro fenômeno. "'13

Além de aplicável a todos os campos de ação do homem, o conceito de forma inserese também nas estruturas internas dele próprio. Todas as experiências vividas são arquivadas na memória - mental e corporal - enquanto formas resultantes de ordenações de informações diversas. Uma lembrança ou estímulo externo pode acionar complexas estruturas de relações que vão de imagens a tensões musculares, passando por sensações nos órgãos internos, emoções, dados apreendidos, idéias assimiladas, orientações espaciais e vivências sociais. Todas organizadas em requintadas ligações entre si que podem ser refeitas em infinitas combinações, cada qual reportando-se a significações distintas.

\footnotetext{
${ }^{13}$ Fayga Ostrower - Criatividade e processos de criação - p. 79
} 
Neste trabalho usaremos o termo "forma" para nos referirmos a qualquer tipo de organização (espacial, conceitual, plástica, sonora ou de movimento) que pressuponha conexões específicas e determinantes da sua identidade. Procuraremos demonstrar como este conceito pode ser utilizado como ferramenta para o aprimoramento do trabalho do daquele que procura expressar-se através do teatro.

2.

\title{
REFERENCIAIS PARA A CRIAÇÃO
}

\author{
MEMÓRIA
}

"Todo perceber e fazer do indivíduo refletirá seu ordenar íntimo.",14

Aquele que se propõe a criar em arte parte da sua vontade de dizer algo sob o seu ponto de vista. A criação tem início, portanto, sempre na realidade que já existe e será por nós reorganizada numa nova forma que abarcará o conteúdo de uma materialidade e as nossas vivências anteriores.

\footnotetext{
${ }^{14}$ Fayga Ostrower - Criatividade e processos de criação - p.26
} 
Desde as primeiras reflexões e experimentos que resultarão em uma obra de arte, estamos interligando os elementos que se apresentam diante de nós segundo critérios que seguem valores estabelecidos pela cultura a que estamos expostos, pois os valores culturais determinam boa parte do que é percebido e permanecerá na memória. Esses dados de qualquer natureza passam a formar nosso acervo pessoal de referências e tornam-se parâmetros que normatizam a absorção das experiências vividas posteriormente. As formas armazenadas na nossa memória são, portanto, a um só tempo as luzes que destacam particularidades da experiência global a que estamos submetidos constantemente, como também são elas que atribuem valores ou renegam completamente certos objetos, fatos ou informações recebidas.

As coerências e significados que encontramos ou atribuímos às novas vivências são sempre resultados de ações seletivas pois a memória já preservou somente aquilo que nossa mente percebeu como importante. Somente o que é passível de ligar-se a esse "arquivo interno" é reconhecido por nós como coerente. Isso acontece porque a percepção se encarrega de escolher em meio aos milhares de estímulos que recebemos a cada segundo aqueles que nos são mais significativos por fatores de interesse, necessidade ou referência. É por esta razão que sempre parecerá saltar aos nossos olhos aquilo que é de maior relevância.

Todo o nosso "arsenal de referências" está permanentemente disponível e pronto para entrar em ação. Quando iniciamos um processo de criação, imediatamente as conexões relevantes se destacam e vêm a tona, ligando-se ao estímulo que acionou o mecanismo de percepção. Passamos então automaticamente a um processo de testes onde as relações são feitas e desfeitas repetidas vezes até que encontremos uma forma de organizar nossas referências internas num todo coerente com os elementos externos que escolhemos ou que se apresentaram diante de nós.

\section{PERCEPÇÃO}

"Todo conhecimento nosso origina-se em nossas percepções."

\footnotetext{
${ }^{15}$ Irma Richter, citado por Fayga Ostrower - Criatividade e processos de criação - p.46
} 
Conhecimento adquiridos ao longo da vida chegam até nós através da nossa percepção, seja por identificarmos fenômenos ou por compreendermos relações. Nossa percepção nos conecta ao mundo agindo como um filtro que separa de todo o resto aquilo que, por qualquer correspondência, agradável ou não, torna-se relevante enquanto informação. Essa filtragem natural age excluindo tudo o que, naquele momento em particular, não se mostra atraente, mas pode posteriormente deter-se sobre detalhes ignorados em ocasiões anteriores. Essa limitação é que estabelecerá as características de uma construção artística, seja ela empreendida pelo artista ou pelo observador que estabelece suas próprias conexões com a obra terminada que está diante dele.

Em dado momento, algum assunto interessa profundamente o artista e ele passa a investigá-lo. Pode se tratar de um material, um tema, uma narrativa, um suporte, qualquer coisa enfim. A simples seleção deste interesse inicial já é revelador, pois o que foi percebido somente destacou-se do contexto em que estava pelo fato de encontrar ressonância nas formas já instaladas no indivíduo. O sentido foi estabelecido pelos referenciais que foram reordenados numa relação com novos dados.

Um aspecto curioso dessa conexão entre os referenciais e as vivências atuais é que sempre pode ocorrer uma ordenação significativa, porque nossa mente invariavelmente vai procurar sentido em tudo o que se apresentar diante dela. É a necessidade humana de compreender o mundo já que compreendê-lo é dominá-lo. Mesmo nas ordenações mais absurdas e inverossímeis, a mente busca a significância. Ao perceber um evento imediatamente projetamos nele alguma relação que nos viabilize a sua compreensão.

A percepção nos leva a analisar, comparar, relacionar, separar, delimitar e generalizar no instante mesmo em que ocorre. Ela capta a importância dentro de uma generalidade que também é percebida e a conecta a outras importâncias e generalidades internas. Estamos falando de partes e todos que não são fixos e podem se redistribuir e trocar de lugar diversas vezes durante a ação de perceber. Os contextos vão assim se sucedendo, cada vez numa ordenação renovada. Isso acontece por, a cada elemento apreendido, iniciarmos a busca por uma forma totalizada e acrescida desta informação mais recente que não deve, contudo, ser simplesmente anexada. O novo deve transformar toda a configuração anterior, 
reestabelecendo a integridade das partes em um processo altamente dinâmico e em constante movimento.

Outra questão relevante é que a percepção acontece fora do universo conceitual que deve ser expresso em palavras porque se dá através da forma. Ela pode até ser transmitida verbalmente no segundo seguinte, mas no preciso momento em que ocorre a percepção apenas se dá a conhecer de imediato, acionando todos os repertórios emocionais, sensoriais e intelectuais a um só tempo. O pensamento conceitual precisa de uma conversão da materialidade do fenômeno em questão para a estrutura processual do intelecto, que é basicamente oral. Essa tradução não acontece instantaneamente porque nenhuma conversão, por mais rápida que seja, é instantânea. Já a apreensão pela forma dá-se de imediato pois ela nunca se separa da matéria que a constitui.

\section{INTUIÇÃO}

"Os processos intuitivos ocorrem de modo não conceitual, são processos de forma" $"$.

A intuição age da mesma forma que a percepção: de maneira extremamente organizada e objetiva. Quando intuímos estão em ação todas as funções ordenadoras da percepção que selecionam um alvo em meio aos elementos que se apresentam diante de nós e rastreiam dentre as referências já cristalizadas em nós aquelas que se conectam com coerência ao foco da nossa atenção. Também no mecanismo intuitivo ocorrem ações mentais de equacionamentos que nos levam a comparar, buscar alternativas, avaliar as chances e concluir.

A diferença entre esses dois processos está relacionada à execução de ações. A percepção traça uma teia de relações externas e internas - que também se conectam entre si dando particular destaque a algum ponto que mereça ser privilegiado na nossa atenção naquele instante. A intuição nos permite selecionar com precisão, dentre todas as

\footnotetext{
${ }^{16}$ Fayga Ostrower $-\underline{\text { Criatividade e processos de criação }}-$ p. 69.
} 
combinações perceptíveis nessas estruturas que estão dentro e fora, aquela que possibilitará um resultado mais coerente e satisfatório, encurtando, talvez, o tempo dedicado às experimentações. É através do intuir que escolhemos o caminho mais seguro entre as muitas combinações possíveis. É um recurso imensamente poderoso de que dispomos pois nos possibilita a avaliação imediata de todos os ângulos de uma questão e nos auxilia a fazer a opção mais viável com extrema rapidez.

\section{ACASOS E CRIAÇÃO ARTÍSTICA}

"As pessoas estão é receptivas; receptivas, a partir de algo que já existe nelas em forma potencial e que encontra no acaso como que uma oportunidade concreta de se manifestar.",17

Não é incomum escutarmos relatos acerca das condições pouco metodológicas em que estavam imersos artistas, cientistas, professores ou administradores quando subitamente "tropeçaram" na solução para o problema com o qual estavam trabalhando. Numa experiência quase mística, a luz finalmente se faz e, a partir daí, dá-se apenas a aplicação prática do conhecimento subitamente adquirido. Nenhum daqueles que passou por tal experiência negalhe a força e a validade e muito menos o mérito dos resultados alcançados.

Esse fato, tão freqüente entre aqueles que desenvolvem práticas criativas, não se deve à providência divina. Nossa mente continua presente e ocupada com todas as questões que lhe são importantes e, ainda que de forma mais tranqüila e relaxada talvez, permanece experimentando combinações e buscando ao seu redor ordenações que, conjugadas àquelas que já possui, possam resolver suas necessidades. Um dos exemplos mais dramáticos é o das súbitas "iluminações" que acontecem em sonhos. Não se trata aqui de analisar mais profundamente as conclusões a que chegaram psiquiatras e neurologistas acerca das atividades cerebrais durante o sono. Basta lembrarmos que essa informação não é mais novidade.

Quando parecemos "trombar inexplicavelmente" com a resposta ou com algo de extrema utilidade para o avanço de uma pesquisa (artística ou científica) o que de fato ocorre

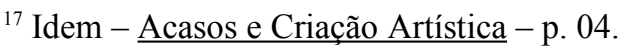


é que mais uma vez a percepção atuou como filtro, rastreando ao nosso redor em busca daquilo que precisamos. Na maioria das vezes o acaso já estava exatamente naquele mesmo lugar antes, já cruzamos com ele repetidas vezes, mas não necessitávamos dele como agora. Os acasos estão sempre intimamente ligados à nossa capacidade de escolhermos em meio a um ambiente caótico as informações que nos serão úteis. O que parece acidental é absolutamente intencional, ainda que não inteiramente consciente.

\section{ASSOCIAÇÕES}

“Minhas queridas associações... Procurem se inspirar nas associações de idéias. Trabalhem com elas. No teatro, eu não faço mais do que me aproximar da compreensão da enorme força que têm as associações de imagens. Aqui há um tesouro infinito de possibilidades."

Meyerhold ${ }^{18}$

As conexões entre nosso repertório pessoal e aquilo que é captado pela percepção na experiência podem também resultar numa nova forma graças ao papel desempenhado pelas associações, base formadora da nossa imaginação, e também responsáveis pela seleção interna de estruturas formais, como a percepção o é pela seletividade daquilo que é externo. Quando associamos estabelecemos relações que às vezes correspondem a semelhanças ou diferenças evidentes. Por vezes um único fragmento, de um ângulo menos evidente da forma existente, conecta-se a um aspecto ainda menos aparente do nosso repertório. Neste momento dá-se a semente da criação, pois ocorre uma associação que pode dar um rumo totalmente inusitado à forma que se estabelecerá a partir dela.

Os desdobramentos que podem se seguir a uma associação não são absolutamente desprovidos de regras, mas seguem critérios mais livres do que as estruturações que se originam a partir de combinações de repertórios com sentidos próximos ao estímulo. Associações são quase sempre fruto de ligações tênues e rápidas, um movimento frenético de idéias apoiado precariamente numa ponta da forma original. Talvez seja o momento mais concretamente verbal do processo criativo porque muito do que imaginamos a partir das associações é estreitamente ligado à fala, pois faz uso dela para deslocar-se de um significado a outro.

\footnotetext{
${ }^{18}$ Conrado (org.) citado por Armando Sergio da Silva - Oficina da Essência - p. 32
} 
Entretanto, é importante frisar que mesmo esse discurso implícito num roteiro de associações não é exclusivamente conceitual. As associações, apesar de serem vinculadas às palavras, usam-nas para invocarem materialidades conectáveis à forma examinada e, por essa razão, mantém o seu vigor e aplicabilidade no desenvolvimento de uma obra expressiva.

É importante definir aqui o que entendemos por expressividade. Quando um artista produz uma obra verdadeira, o faz em perfeita sintonia com três aspectos da sua individualidade: sua sensibilidade (relacionada à sua disponibilidade para estabelecer conexões), cultura (o universo social, espiritual e familiar em que está inserido) e opções conscientes (escolhas com objetivos definidos a serem alcançados). E não poderia ser de outro modo pois o artista é aquele que com mais freqüência se mantém em sintonia consigo mesmo. Isso se dá pelo fato dele estar sempre retomando suas formas interiores e reorganizando-as para se adequarem a novas realidades que estão surgindo durante o ato de criar. A obra de arte é, portanto, solidamente apoiada na individualidade fortalecida do artista e é essa conexão que ocorre em aspectos tão essenciais da humanidade que outorga a uma obra concebida nessas bases a classificação de "expressiva".

Durante a criação de um objeto artístico acontece uma intensa conscientização do real, mesmo quando ele é formulado dentro de uma subjetividade. Isso ocorre porque num processo vivo de criação estamos confrontando permanentemente as formas que vivenciamos e aquelas que viabilizam a comunicação com o mundo. É verdadeiramente expressivo aquilo que apresenta o essencial, não no sentido de síntese, mas naquilo que é compreendido por todos por ser absolutamente humano. Essa é a razão pela qual as grandes obras de arte ultrapassam os séculos e permanecem sempre atuais e emocionantes. Porque continuam falando conosco naquilo que é mais nosso.

\section{LIBERDADE X LIMITAÇÃO}

"Embora o ato de criar signifique um ato de abandonar-se e vagar em mundos ignorados, acompanhao, no entanto, um senso de precisão. "19

${ }^{19}$ Fayga Ostrower - $\underline{\text { Criatividade e processos de criação }}-$ p. 162. 
Criar implica em aceitar a existência dos limites, nossos e do veículo que escolhemos para nossa expressão. Mas não se trata da aceitação resignada diante da imperfeição. É a consciência da limitação enquanto afirmação das qualidades a serem experimentadas, conhecidas e selecionadas enquanto essenciais para se construir uma forma completa. É escolher com consciência e propósitos claros. Isso é ser verdadeiramente livre. Nesse sentido é importante ressaltar o valor da regra para o desenvolvimento do pensamento e da produção artística. O limite é o que esclarece a natureza de um fenômeno. É o que define uma situação na sua extensão total. Não são obstáculos, mas pistas que apontam caminhos e evitam que nos sintamos perdidos no caos improdutivo do "tudo pode". A limitação funciona como as regras de um jogo que especificam os objetivos e as formas de atingi-los, dando-nos total liberdade de agir através delas.

A limitação é libertadora pois impõe a mobilidade. A partir dela temos uma direção definida a seguir, sabemos para onde estamos indo. A falsa liberdade com ausência absoluta de regras imobiliza o artista porque exclui a necessidade de ordenamento lógico, força motriz do pensamento e da criatividade e necessidade primordial do ser humano. Ansiamos pela ordem e temos necessidade de submeter a realidade ao nosso domínio através do entendimento. Por isso o ato de criar está concretamente relacionado ao trabalho enquanto ação movida pela necessidade de solucionar problemas específicos, vinculando sempre a adequação do objetivo aos instrumentos que se dispõe para alcançá-lo

E não estamos nos restringindo aos limites momentâneos da matéria que está sendo formada, nem somente às possibilidades pré-existentes no artista. A cada passo, cada escolha, uma nova limitação é trazida, redirecionando as possibilidades da obra:

“... a linha inicial traçada por uma pessoa, esse primeiro fato físico produzido determinou com seu impulso o caráter do resultado final. Definiu uma delimitação a qual encadeou outras delimitações. Reduziu as possibilidades infinitas para possibilidades incontáveis ainda, mas não mais infinitas. „20

\footnotetext{
${ }^{20}$ Fayga Ostrower - $\underline{\text { Criatividade e processos de criação }}$ - p. 164.
} 
Criar é ser altamente seletivo na busca de ordenações absolutamente adequadas entre si, consigo mesmo e com toda uma realidade cultural que nos abarca e ao objeto que criamos. Impossível criar de forma expressiva e significativa sem esse perfil. Não se trata de ser original no sentido de criar algo que não existe. A originalidade acontecerá pelo fato de que cada artista traz as suas referências a partir de memórias e cultura únicas, e se ele realizar as conexões deste seu material pessoal com a essência da matéria de forma realmente coerente ocorrerá uma criação original e capaz de estabelecer contato real com o espectador por trazer em si uma verdade inquestionável numa linguagem que não precisa de intermediações - a da forma.

\section{LINGUAGEM E CONTEÚDOS}

"Só se cria dentro da especificidade de uma determinada matéria e só com o pleno domínio de sua linguagem. ${ }^{21}$

Quando falamos de criação nos referimos a dar ordem estabelecendo relações entre estruturas, materiais ou conceituais, que são em si formas. Cada forma possui suas características que determinam as possibilidades de ação do artista sobre ela. A união dessas duas qualidades estabelecem a linguagem da matéria como se dá na língua falada. $O$ alfabeto aceito por um determinado código lingüístico estabelece as possibilidades de organização das palavras, e nem todas as organizações são válidas dentro das infinitas possíveis.

Cada linguagem possui suas características formais que somente revelarão seus segredos ao artista que dominar sua essência. Essas características são tão intrinsecamente ligadas à forma que torna-se impossível fazer transposições entre as linguagens a partir das formas por ela estruturadas. Não se pode pintar uma música nem compor uma sinfonia como tradução de um movimento. São ordenações absolutas e incomunicáveis enquanto resultados

\footnotetext{
${ }^{21}$ Fayga Ostrower - Acasos e Criação Artística - p. 219.
} 
finais. Os conteúdos expressivos veiculados por essas formas só podem ser expressos por elas e, uma vez alterados os veículos, também os conteúdos se reestruturam e se alteram.

A ponte entre as linguagens somente pode ser erguida a partir dos conteúdos abstratos que cada uma delas pode compartilhar com as demais. Pode-se trabalhar a idéia de contraste em campo artístico - pintura, escultura, dança, teatro ou música - mas para cada um deles o conceito só será expresso com verdade se os elementos utilizados forem corretamente empregados e se a idéia for abordada no seu conteúdo essencial, e não através de uma forma estabelecida em estrutura já resolvida.

\section{3.}

A PONTE

"Uma espécie de antropofagismo, de tradição muito nacional."22

Todo o conhecimento exposto aqui até este momento foi o alicerce teórico que orientou os procedimentos apresentados no relato que se segue. Este caminho para a cena através de princípios aprendidos através da plástica, que até então foi sempre percorrido sem preocupações com qualidade e solidez de conceitos, seria agora testado na sua eficácia sob os olhos de pessoas com ampla experiência e conhecimentos aprofundados da linguagem teatral e suas especificidades.

É sempre muito difícil falar com objetividade de uma vivência. Como pintar com todas as cores as emoções e frustrações que nos acompanham na prática da arte? Aqueles que já caminharam por essas estradas poderão imaginar com mais precisão as sensações vividas por nós, mas em que medida? Até onde dissertações como esta podem de fato ser ${ }^{22}$ Armando Sérgio da Silva - Oficina da essência - p.19 
consideradas retratos fiéis do que se passou? Esta é uma dúvida que se manterá firme até o fim destas páginas e com certeza acompanhará o leitor que tem questionamentos semelhantes dentro de si. Esperamos que a imaginação daqueles que percorrem essas linhas seja mais eficiente no entendimento de algo tão intenso quanto a prática do ator do que as mãos que as escrevem.

Alguns pontos precisam estar muito claros a partir deste ponto:

- Não nos propusemos a uma análise aprofundada da figura de Fayga Ostrower, ou de qualquer dos indivíduos que são aqui mencionados como influenciadores dessa experiência. O pensamento de cada um deles foi estudado na medida das nossas necessidades e nos limites da sua ressonância com nossos próprios anseios e certezas.

- A meta que colocamos à nossa frente foi verificar a possibilidade de diálogo entre o mecanismo criativo conhecido e já aplicado por nós em produções vinculadas às artes plásticas com as necessidades específicas da elaboração de uma obra cênica, levando-se em conta a busca do ator por uma interpretação sempre viva, verdadeira e destituída de formatações prévias.

- Queremos examinar as diferenças entre o artista e o mortal comum, que eventualmente sinta a necessidade de criar, ao longo de um processo criativo que envolva os procedimentos que se originaram na conversa da plástica com o teatro. Elas de fato existem na dimensão que normalmente julgamos? 


\section{II.}

\section{FALANDO DA} PRÁTICA 


\section{1. OS PRIMEIROS PASSOS}

\section{O PONTO DE PARTIDA}

Quando retomamos os trabalhos em 2007 o grupo de pesquisa, que se manteve razoavelmente o mesmo desde as primeiras atividades em 2006, optou por dar novos rumos à produção. Depois de algumas considerações sobre temas relevantes e de interesse de todos chegamos ao nome de Shakespeare e a "Hamlet". Optamos por não encenar a peça da forma como se apresenta, mas procurando situações contemporâneas ou suficientemente neutras para alcançarem a universalidade e que tivessem relação com aquelas que se encontravam descritas na obra. Esse direcionamento foi dado porque todos acreditavam que o teatro deve dialogar com seu tempo e essa mensagem é mais facilmente encaminhada através de contextos familiares ao público a que se destina. 
Foi-nos pedido, enquanto primeira tarefa, a seleção de uma passagem de "Hamlet" como ponto de partida. Iniciando pelo trecho escolhido, deveríamos contar para os demais integrantes do grupo uma história baseada na cena escolhida, mas que não denunciasse sua origem $^{23}$. Fomos assim despachados para casa com o próximo encontro marcado para o mês seguinte, quando todos já teriam tido tempo de avaliar suas expectativas e considerar o projeto válido ou não para os seus objetivos pessoais.

Passados os trinta dias todos decidimos por manter a sugestão e um formato semelhante ao que já vínhamos utilizando nos encontros de estudo, com tarefas a cumprir, apresentações quinzenais e olhos voltados para a construção de um espetáculo. E para que não fôssemos obrigados a apenas juntar cenas desconexas ao final do processo, estabeleceu-se que no primeiro semestre iríamos trazer nossas idéias e dúvidas no formato de "performances" a serem mostradas enquanto material de estudo, para que outros participantes, que se sentissem atraídos pelas propostas, pudessem se aproximar e participar com seu próprio procedimento e repertório. Durante o segundo semestre seriam apresentados "workshops" desses procedimentos, esclarecendo os caminhos que estavam sendo trilhados para alcançar os resultados que seriam vistos ao longo do estudo. Assim todos acompanhariam a evolução de cada a cena, poderiam dar sua contribuição ou mesmo participar dos processos que mais lhes interessassem.

O caminho percorrido até a concretização da cena denominada "Sem título técnica mista sobre palco" esteve dividido em 6 momentos bem definidos:

1. Escolha e análise do fragmento de Hamlet que seria utilizado como material para criação.

2. Associações a partir do texto.

3. Seleção, organização e composição dos estímulos relacionados a essas associações.

4. Aproximações e troca de estímulos na parceria que se formou.

5. Procedimentos de construção.

- Experimentação das limitações e do repertório das pesquisadoras envolvidas na construção da cena.

\footnotetext{
${ }^{23}$ Como suporte teórico para nossa aproximação com Shakespeare foi sugerido o livro "Shakespeare nosso contemporâneo" - Jan Kott.
} 
- Composição com as potencialidades descobertas.

- Avaliações do grupo.

- Retomadas.

6. Fixação e detalhamento da cena final objetivando a sua recepção pelo público.

Cada uma dessas etapas é prevista por Fayga na sua análise dos mecanismos da percepção seletiva e das associações que desencadeiam a criação. É desta seqüência de ações que ela trata também quando faz referência às sucessivas avaliações dos limites da matéria, que vai delineando com suas possibilidades a relação com o artista e a forma final que será gerada. A criatividade tem, portanto, pode ser organizada com objetividade em momentos definidos com objetivos claros. Essas fases da criação são também discriminadas pelo professor Armando em seu livro:

“...primeiro momento:conhecer, desvendar o objeto, já que o que lhe foi dado não passa de um indício, de uma aresta, de um estímulo. (o aluno-ator) Deve depois criar esse objeto através do seu corpo e mente, ou seja, incorporar esse objeto e, como se ainda não bastasse deve transformar-se esse objeto em um dado intencional de comunicação, em um signo articulado para a percepção do espectador. São estas três ações, patamares, fases, que estabeleço como sistemática para o aluno-ator. "24

Apesar de referir-se à formação de atores na sua pesquisa, o mesmo caminho é apontado como necessário ao artista maduro quando elabora sua obra:

\section{HAMLET}

Numa primeira leitura do texto optou-se pela seleção da cena que seria utilizada com base em critérios de gosto pessoal, sem grandes análises literárias (anexo 1 p. 106). Havia naquele momento a disposição de confiar na intuição que, segundo Fayga, conduziria a

\footnotetext{
${ }^{24}$ Armando Sergio da Silva - Oficina da Essência - p.29.
} 
percepção automaticamente para a passagem que tivesse mais pontos de conexão com o o universo pessoal do artista, propiciando-lhe maiores chances de desenvolver um trabalho verdadeiro e consistente. Nesse aspecto eram também novamente encorajadoras as palavras da Oficina da Essência:

"As coisas atraem nossa atenção pelo ângulo que têm mais relação com o nosso temperamento, com nossas paixões e nosso estado. São essas relações que fazem com que elas nos afetem com maior força e que delas tenhamos uma consciência mais viva" ${ }^{\prime 2}$.

É preciso reforçar a importância que esse primeiro momento da criação representa para o produto final. As sementes de uma sequóia trazem em si todas as características que farão dela um gigante das florestas. A escolha dos materiais de trabalho na plástica (suporte, qualidade de tintas, pincéis, tema e enquadramento) equivale à seleção dos estímulos que serão manuseados durante o trabalho do ator para a construção da sua cena. É claro que serão dados direcionamentos mais variados durante o processo cênico uma vez que ele abarca conteúdos de imagem, som, mensagem, espaço, tempo e movimento (por vezes também estímulos tácteis e olfativos são abordados), o que não acontece com um quadro, por exemplo, que age sobre os sentidos do observador através de alguns desses canais, não todos. O leque de itens a serem selecionados e estudados é maior, mas o procedimento para com cada um deles é similar ao que se dá nas artes visuais.

Os rumos que seriam posteriormente cobertos pela pesquisa foram determinados nesses primeiros contatos entre o repertório pessoal e o material de Shakespeare. Uma vez iniciado este diálogo, foi imediatamente acionado um mecanismo recorrente nos processos criativos dentro e fora do teatro: as associações.

"Tomemos um exemplo ainda mais concreto: por que a partir de uma representação concreta - um pedaço de cera arredondado, amarelado, com cheiro específico, pesado, etc. - uma série associativa toma determinado rumo (a atenção concentra-se no amarelo, por exemplo) desencadeando uma série, entre muitas outras possíveis? Se todas são compossíveis logicamente, os princípios mecânicos internos são obviamente

${ }^{25}$ Ibid., - p. 27. 
insuficientes para explicar isso. Se a atenção do sujeito se volta para a cor, deve haver algum motivo para essa escolha e a conseqüente exclusão de outros fatores. ${ }^{26}$

"Minhas queridas associações... Procurem se inspirar nas associações de idéias. Trabalhem com elas. No teatro, eu não faço mais do que me aproximar da compreensão da enorme força que têm as associações de imagens. Aqui há um tesouro infinito de possibilidades. "27

Nessa fase inicial, onde predomina a ação da percepção, destacou-se a cena da discussão de Hamlet com sua mãe no quarto dela, onde ele revela sua sanidade e acusa a rainha de estar agindo de forma incorreta ao deixar tão rapidamente de lado o seu luto de viúva, além de aliar-se ao assassino do próprio marido (anexo). Uma cena intensa, onde mágoas profundas são mostradas e ilusões são destruídas dentro de uma relação que sempre é tida como perfeita e inabalável: a de mãe e filho. Algumas frases se mostraram particularmente instigantes enquanto material para criação por abrirem espaço para conexões significativas e coerentemente ligadas a repertórios pessoais.

O trecho eleito como matriz foi uma das mais fortes falas do príncipe:

HAMLET: Mirai este retrato e mais este outro, que dois irmãos fielmente representam; vede a graça que encima esta cabeça, cachos de Apolo, a fronte alta de Júpiter, o olhar de Marte, a mando e à ameaça. afeito, o porte de Mercúrio, o mensageiro, quando pousa nos cumes altanados; uma forma, em resumo, perfeitíssima, em que os deuses seus selos imprimiram para que o mundo visse o que era um homem: esse, foi vosso esposo. Agora o resto: eis vosso esposo, espiga definhada que o irmão sadio empesta. Tendes olhos? Deixastes a pastagem deste belo monte por um pau? Ah! tendes olhos? Não chameis a isso amor, que em vossa idade o sangue se arrefece, fica humilde e obedece à razão. E que razão passa deste para este? Sois sensivel, pois vos moveis; mas tendes os sentidos paralisados. A loucura acerta; nunca os sentidos ficam subjugados pela paixão, a ponto de falharem totalmente na escolha. Que demônio vos logrou de uma vez na cabra-cega? $O$ olho sem tato, o tato sem visão, o ouvido só por si, o olfato apenas, a menor parte, em suma, de um sentido verdadeiro, jamais se estontearia desse feitio. Pudor, por que não coras? Se nos ossos de uma matrona, inferno, te rebelas, que a continência fique, para os moços ardentes, como a cera, que amolece no próprio fogo; nem de mancha fales, quando no ataque se atirar o instinto, uma vez que é tão quente a própria geada e a razão é alcoveta da vontade. ${ }^{28}$

\footnotetext{
${ }^{26}$ Étienne Condillac citado por Armando Sergio da Silva - Oficina da essência - p. 29.

${ }^{27}$ Meyerhold - citado por ibid., p. 32.

${ }^{28}$ Hamlet - Ato III, cena IV. Grifos meus.
} 
As frases destacadas foram as que ressoaram mais intensamente, seja enquanto idéias que poderiam suscitar desdobramentos interessantes (a mando e à ameaça afeito) ${ }^{29}$, ou como figuras completas em si mesmas que podiam ser utilizadas enquanto tal numa composição (olhar, idade, amor, $\underline{\text { demônio }}, \underline{\text { pudor }})^{30}$. Ao final do processo é verificável que essas primeiras associações mantiveram-se presentes até a conclusão do trabalho. Podemos discriminar as seguintes impressões, hipóteses e pontos que chamaram a atenção entre as informações reais ou parciais apresentadas pelo fragmento escolhido:

- Uma revelação.

- A loucura como única justificativa para atos aparentemente impensados.

- O confronto forçado com seus "maus atos".

- Um erro cometido pela fraqueza de opor-se a ele.

- A idealização de uma figura (o pai).

- A mãe que deveria ser perfeita, mas é falha e fraca aos olhos do filho.

- As pessoas não são como nós as idealizamos e isso é uma dura constatação.

- Um pai que poderia ter sido violento e frio e que, no fundo, talvez não merecesse ser amado.

- Uma mulher que pode ter deixado de amar.

- que precisava "se virar" numa época difícil para o sexo feminino.

- que queria se manter no poder.

- que talvez conheça uma outra versão da história

- que guarda um segredo.

A situação de Gertrudes mostrava-se mais interessante, talvez porque más escolhas no amor são uma realidade que todas as mulheres conhecem e nosso grande medo é que esse sentimento não seja maravilhoso nem eterno como gostaríamos. A falta de explicações da rainha diante das acusações de seu filho abria uma infinidade de conjecturas plausíveis e

\footnotetext{
${ }^{29}$ Essas palavras foram percebidas enquanto indicadoras de qualidades desagradáveis de serem encontradas num "marido ideal".

${ }^{30}$ Termos que carregam em si sentidos vastos e passíveis de articulações diversas e fortes.
} 
estimulantes. Toda uma teia de conexões estava ali, encoberta por palavras que normalmente dirigiriam nossa atenção para outro enfoque da história - Hamlet e sua vingança. Mas vinganças são coisas de menino. As meninas gostam de falar de amores e desilusões.

Desde o momento em que esses pensamentos surgiram, as indicações que a própria Gertrudes dava não mais interessavam. Somente a verdade que ela guardava para si parecia saltar do texto. Ela passou a ser como a guardiã de um mistério imaginado e que não é visível. Vivências se conectaram àquelas poucas frases num arranjo que já não correspondia mais à Gertrudes de Hamlet, mas a um único aspecto dela que se mostrou tocante e com o qual se estabeleceu uma brincadeira animada, fazendo e refazendo ordenações de fatos e características anteriores ao momento descrito a partir de um material interno da leitora que foi acionado. Que vivência misteriosa esta mulher tinha que o jovem e rancoroso Hamlet não podia identificar? Será que esse mau supostamente praticado pela personagem não seria algo extremamente funcional? Algo que de alguma maneira fosse necessário por questões de sobrevivência ou sanidade?

Mas ainda restava a tarefa de elaborar uma história para contar ao grupo. E aqui surgiu a primeira grande dificuldade. Ao longo do processo ocorreram quatro grandes crises que foram de suma importância para o amadurecimento desta pesquisa e para que uma maior compreensão do processo criativo fosse alcançada. A primeira delas aconteceu logo no início da jornada, nessa primeira tarefa a ser cumprida: a história.

Talvez devido ao treinamento pela plástica foi sentida certa dificuldade em estruturar uma narrativa com começo, meio e fim no formato linear que define a língua falada e escrita. Nem todas as mentes têm nessa linearidade a sua expressão mais confortável. Durante este processo em particular os melhores resultados foram conseguidos pelo pensamento através de "flashes" que às vezes são difíceis de organizar por manterem-se numa percepção global que pode ser muito completa, mas em princípio reluta em ordenar-se no formato oral. Numa primeira tentativa, buscou-se elaborar uma história construída sobre as bases estruturais de romances conhecidos que trouxessem esse mesmo contexto de desilusão, descoberta de segredos e males que são praticados sem justificativa aparente, numa tentativa de alinhar as manchas de informações que existiam. 
Entre as muitas histórias que correm paralelamente em "A leste do Éden"31, é particularmente marcante o triângulo amoroso dos dois irmãos e a estranha Cathy, e os gêmeos resultantes dessa complexa relação. A personagem do romance é a personificação de tudo aquilo que pode ser vil em uma mulher. De aparência frágil e delicada ela é, na verdade uma assassina fria e promíscua, exatamente o que Hamlet via na própria mãe. A mulher decadente do final do livro foi a inspiradora da seleção de uma série de imagens que traziam marcas de histórias nada românticas e que representar a razão do silêncio de Gertrudes na sua discussão com Hamlet. Essa primeira associação foi bastante produtiva enquanto fornecedora de material criativo, mas não foi suficiente para gerar uma narração própria.

Ao tentar utilizar uma estrutura pronta inserindo nela novos elementos procedia-se à colocação de peças redondas em buracos quadrados. O resultado não foi satisfatório porque consistiu em tratar formas acabadas, portanto já estabilizadas em ordenações equilibradas, como material bruto a ser ordenado. É como querer criar uma obra de arte pondo a cabeça de Monalisa num corpo de um Botero sobre o fundo da Guernica de Picasso. No máximo se obtêm três obras destruídas. Isso pode funcionar enquanto exercício de composição quando se está fazendo as primeiras incursões nesse campo, mas não resultará numa obra nova com sua própria coerência interna.

A primeira narrativa foi o mais completo caos. Muitas idas e vindas com montes de informações para esclarecer cada ponto. O conhecimento prévio de todos os contextos envolvidos na estrutura original permitiria o entendimento, mas ouvintes que não possuíam tal conhecimento não tiveram acesso a todas essas informações e o conjunto permaneceu sem sentido. O que estava sendo narrado não era lógico em principio, porque estava num formato mais familiar àqueles que se utilizam das linguagens visuais: o mapa mundi, com todas as correntes marítimas, caminhos do vento, rotas de navios, tráfego aéreo, acidentes geológicos e pontos turísticos. Um caos, por certo. Absolutamente lindo e interessante para aqueles que se utilizam dessa forma de ordenação, e incompreensível para o resto do mundo. Como não adianta lutar contra a natureza, a "contação de histórias" foi deixada momentaneamente de lado e o trabalho com uma estrutura mental de borrões de tinta, flashes e companhia foi retomado.

\footnotetext{
${ }^{31}$ John Steinbeck - romance que nos serviu de estímulo para a concretização da primeira tarefa.
} 
Buscando parâmetros que auxiliassem na escolha dos estímulos procuramos definir quais aspectos da cena e da interpretação seriam abordados. Foram estabelecidas três qualidades imprescindíveis no contato mais óbvio entre ator e platéia: texto, voz e corpo. Nesse tipo de relação necessita-se de um texto a comunicar, esse texto teria sua mensagem reforçada ou amenizada de acordo com a qualidade sonora da voz que o apresentasse ao público. Um corpo seria visto numa situação não cotidiana e precisava adequar-se a esse momento tão especial. Cada um desses aspectos da interpretação deveria, para atender à proposta de Fayga, ser tratado como elemento participante de uma composição consciente.

Um dos aspectos que interessam a esta pesquisa é a observação de que recursos contribuem para a renovação dos repertórios de voz, corpo e movimento do ator a cada novo trabalho. Tencionamos comprovar que, reordenando-se dados descobertos através de estímulos selecionados em associações com repertórios pessoais, pode-se encontrar caminhos e solucionar problemas de interpretação. A forma resultante dessa ordenação só será orgânica e expressiva se constituída de essências verdadeiras, ou seja, elementos fiéis à vivência do artista e às peculiaridades dos estímulos.

\section{OS ANTEPAROS CRIATIVOS}

O professor Armando indica em seu livro o recurso do uso de anteparos como instrumentos de criação para o ator em início de processo. Em procedimentos intermediados por outras linguagens artísticas o ator se permitiria uma exploração livre da idéia que o move sem o comprometimento de formalizações antecipadas.

“Esta fase se resume no ato de, propositadamente, retardar a experimentação corporal, propriamente dita, através de jogos puros, mediados, escondidos, protegidos por outras linguagens, como: narrativa oral, música, artes plásticas, etc. (...) Através dos exercícios faz uma série de escolhas, que serão fundamentais para a futura composição da personagem. O objetivo é que o ator através desses anteparos, dos pontos de contato fisico, se afaste de uma análise muito cerebral ${ }^{, 32}$

\footnotetext{
${ }^{32}$ Armando Sergio da Silva - Oficina da essência - p. 35.
} 
Essa etapa conduzia primeiramente a uma experimentação de idéias para revelar potencialidades de abordagem.

As mães costumam saber das coisas. Elas já sofreram e se ergueram mais fortes do que antes uma série de vezes. Ocasionalmente até riem das nossas "bobagens" dizendo "Ah se eu tivesse a sua idade com a cabeça que tenho hoje..." É de enlouquecer qualquer filha com dor de cotovelo. $\mathrm{Na}$ verdade, quase todos já tiveram a experiência de verem suas crises pessoais ridicularizadas, normalmente pelos mais velhos. Eles às vezes se zangam, mas normalmente riem muito quando nos debatemos em desesperos que vão passar. Esse tema podia ser vislumbrado na cena de Shakespeare quando se empreendia determinado recorte valorizando um silêncio velado.

\section{Pudor, por que não coras?}

Essa questão do mal presente em todos, mas só assumido em alguns, mostrou-se atraente. Somente a viúva conhecia a verdade que motivou suas ações. Ela era detentora de um conhecimento ao qual Hamlet não tinha acesso e que estava ligado à causa de uma ação repudiada pelo jovem príncipe que, por esse motivo se enfurecia contra a mãe. Referências foram selecionadas a partir dessas idéias básicas consideradas essenciais para a estrutura da cena que se criaria:

- Conhecimento secreto.

- Ilusão perdida.

- Decadência moral que pode ter sua justificativa ou funcionalidade.

- Pessoas que não conhecemos de verdade ou que se transformam a nossos olhos.

- Dor - de perder, de conhecer, de experienciar, de fazer ver.

As referências plásticas que foram sendo escolhidas traziam representações de pessoas (na maioria das vezes mulheres) que possuíam um ou vários aspectos dessa estrutura básica construída como filtro para os estímulos. 
Para a qualidade da voz procurou-se destacar o confronto entre o rancor de Hamlet e o lamento conformado de Gertrudes. Como estávamos procurando por sonoridades, foram descartadas todas as referências que pudessem trazer mensagens reconhecíveis, ainda que minimamente. Chegamos a duas músicas ${ }^{33}$ percebidas intuitivamente como relacionáveis a todas as demais informações colhidas. Essas músicas detêm harmonias e tonalidades estimulantes. As vozes femininas são particularmente agradáveis, pois trazem sons familiares, ecos de reuniões de família recheadas de cantos, diálogos animados, raivosos ou de profunda tristeza aceita como inevitável. ${ }^{34}$

Quanto às vozes masculinas, o aspecto mais impressionante é a extensão do som, que se prolonga por um tempo aparentemente interminável, causando uma impressão de sobrenatural, não humano ou loucura. Numa escuta mais cuidadosa percebe-se que são várias vozes num trabalho de sobreposição de fôlegos que se sucedem sem deixar espaços vazios, o que provoca a sensação de som ininterrupto. Esse exagero aliado a uma qualidade extraordinariamente grave trazia de volta as acusações pesadas de Hamlet contra sua mãe. Estavam ali referências que abriam possibilidades de conexão com material pessoal, condição essencial para a sua seleção.

A decisão de falar sobre amor também determinou uma das primeiras limitações, excluindo uma série de textos e facilitando a busca. Outra circunstância determinante a preferência por um texto narrativo e não dramático. Essa escolha também foi feita guiada por limitações. Limitados conhecimentos de textos dramáticos dificultavam a localização de fragmentos que tratassem do amor, o que resultaria na obrigação de ler produções inteiras para achar as partes adequadas, se houvessem, o que era inviável por questões de tempo. Além disso, o acesso a textos poéticos e narrativos em bibliotecas escolares é bem maior do

${ }^{33}$ Cd World Voices 1 - World Class Records - 1998 - San Francisco - U.S.A.

"Akh Ti Notchenka" com Bielka Nemirovski (12 c. Rússia) 5:26

"Legend" com Huun Huur Tu \& the Bulgarian Voices (17th c. Tuva) 7:38

${ }^{34}$ É interessante como a língua determina a qualidade sonora da voz. É possível franceses e espanhóis pareçam apaixonados mesmo lendo bula de remédio. Temos, contudo, maior contato com povos eslavos, particularmente com imigrantes e descendentes de lituanos. Na Lituânia, como na maior parte dos países daquela região, as emoções são muito fortes apesar da aparência fria das pessoas. Existem canções de profunda amargura que são entoadas pela população com uma qualidade que não é da dor sentida naquele momento, mas da dor conhecida. As canções que falam de partida não são entoadas como no ocidente, com interpretações que parecem estar revivendo o momento exato da perda, com uma emoção ainda quente. Na Lituânia se canta a perda como tristeza certa e parte da vida, que não pode ser evitada. Pode-se reconhecer em mulheres dessas nações, particularmente entre as mais idosas, uma visão fatalista do mundo que às vezes aparece na voz. Para elas a dor e a tristeza são fatos que não se pode recusar, só aceitar e guardar consigo. 
que aos do gênero dramático e este era o local de pesquisa mais viável. Coletâneas de Clarice Lispector e Lygia Fagundes Teles foram os mais investigados.

Dois $\operatorname{contos}^{35}$ dessas duas autoras que traziam situações relacionáveis à toda a estrutura traçada a partir da cena de Hamlet com sua mãe foram separados. Novamente as associações se deram por fragmentos que se conectavam através de um dos múltiplos aspectos da situação de Shakespeare, e não por um sentido geral ou completo. Em "As pérolas" destacou-se a relação do rei e da rainha com o casal descrito por Lygia. Aquele homem vai morrer e a mulher irá sofrer e continuar viva, dando novos rumos à sua rotina. Já no momento retratado o fato mostra-se como irremediável e certo, tanto quanto também é certa a superação da dor da perda.

Lavínia penteava os cabelos. Inclinara-se mais sobre a mesinha, de modo a poder ver melhor o marido que continuava estirado na sua poltrona, colocada um pouco atrás e à direita da banqueta na qual ela estava sentada.

- Pensando em coisas tristes?

- Não, até que não ... - respondeu ele. Seria triste pensar, por exemplo, que enquanto ele ia apodrecer na terra ela caminharia ao sol de mãos dadas com outro? Bem? ..

Era verdadeiramente espantosa a nitidez com que imaginava a cena: o piano inesgotável, o ar morno da noite de outubro, tinha ainda de ser outubro com aquele perfume indefinivel da primavera. A folhagem parada. E os dois, ombro a ombro, palpitantes e controlados, olhos fixos na escuridão. "Lavínia e Roberto já foram embora?" - perguntaria alguém num sussurro. A resposta sussurrante, pesada de reticências: “Estão lá fora na varanda.”

Do texto "Legião estrangeira" a descrição da metamorfose sofrida pela personagem Ofélia (que seria ainda mais significativa num momento mais avançado da pesquisa) foi o que mais interessou porque essa pequena personagem orgulhava-se da sua maturidade. Perceberse criança foi extremamente doloroso. Seu algoz foi a própria Clarice, como Gertrudes se descobre má pelos olhos de Hamlet.

Nela a grande pergunta me envolvia: vale a pena? Não sei, disse-lhe minha quietude cada vez maior,

\footnotetext{
35 "As pérolas" de Lygia Fagundes Teles (Anexo 2, p.110) e "Legião estrangeira” de Clarice Lispector (Anexo 3 , p. 114 )
} 
mas é assim. Ali, diante de meu silêncio, ela estava se dando ao processo, e se me perguntava a grande pergunta, tinha que ficar sem resposta. Tinha que se dar-por nada. Teria que ser. E por nada. Ela se agarrava em si, não querendo. Mas eu esperava. Eu sabia que nós somos aquilo que tem de acontecer. Eu só podia servir-lhe a ela de silêncio. E, deslumbrada de desentendimento, ouvia bater dentro de mim um coração que não era o meu. Diante de meus olhos fascinados, ali diante de mim, como um ectoplasma, ela estava se transformando em criança.

Não sem dor. Em silêncio eu via a dor de sua alegria difícil. A lenta cólica de um caracol. Ela passou devagar a língua pelos lábios finos. (Me ajuda, disse seu corpo na bipartição penosa. Estou ajudando, respondeu minha imobilidade.)

A dualidade era outra característica relevante em todo o material levantado:

- Amor e rancor

- Decepção e ilusão

- Mãe e filho

- Feminino e masculino

- Aceitação e inconformismo

- Conhecimento e ingenuidade

- Agudo e grave

Essas oposições levaram a outras conectáveis não com o texto de Shakespeare, mas com a nova cena que vinha aos poucos emergindo de todos esses referenciais, ainda desordenada, com as conexões se unindo e soltando constantemente, mas já com seus elementos formadores.

- Viúva e noiva.

- Preto e branco.

- Razão e emoção.

- Estabilidade e movimento.

- Silêncio e som.

- Controle e descontrole.

- Fim e início.

- Alto e baixo. 
Essas histórias alimentaram o processo enquanto imagem, mas não se mostravam claramente sendo ditos para uma platéia, porque implicavam novamente em comunicação linear, num encadeamento de informações que não eram confortáveis para nós. Para essa organização em caleidoscópio - que é uma ordenação pessoal, um dos muitos caminhos possíveis de criação, uma maneira de entender, ver e ordenar - esses textos não se adequavam. Faltava o que seria de fato comunicado, e que foi encontrado na obra de Paulo Mendes Campos. $^{36}$

Esse texto fala da inevitabilidade de que o amor acaba e descreve diversas situações em que se percebe essa realidade inquestionável. São momentos comuns e vários deles possivelmente encontrem correspondência na vida de qualquer pessoa. $\mathrm{O}$ ritmo da mensagem se impõe ao leitor por se tratar de uma obra sem pontos finais além de em dois momentos específicos: um logo no início, para dar peso à afirmação "o amor acaba”, e outro no final, depois da descrição de cinqüenta situações ou maneiras onde o amor tem seu fim. Essa qualidade desprovida de pausas imediatamente identificou essa obra com uma das sonoridades já escolhidas. Além disso, todas as informações compõem um único e mesmo quadro. São como fragmentos de um espelho onde o conjunto compõe sim uma imagem, que é também encontrada em cada uma das partes, não importando realmente a ordem em que elas sejam observadas.

Nessa fase inicial da criação estamos numa condição de muita incerteza e fragilidade. Com muita facilidade adotamos opiniões e imagens alheias como sendo nossas, o que fatalmente tem suas conseqüências ao longo do percurso. A mais comum é reproduzirmos formas prontas e sem sentido real para nós, tornando a criação falsa, vazia ou pelo menos inconsistente. Quando já assentamos alicerces em solo próprio podemos ouvir outras opiniões porque, para que se encaixem no mosaico que está sendo formado, precisarão ser reordenadas, passando a ser nossas. Já havíamos alcançado esse patamar e o livro de Kott pode ser examinado.

$\mathrm{O}$ autor analisa as principais obras do escritor renascentista enquanto estruturas de conflitos humanos perfeitamente transferíveis para qualquer época e abertas o suficiente para

\footnotetext{
${ }^{36} \mathrm{O}$ amor acaba - Paulo Mendes Campos - Os treze melhores contos de amor - organizado por Rosa Amanda Strausz (anexo 4 p.121)
} 
que delas se escolha uma face para dirigir a abordagem. Kott descreve montagens e traduções avaliando a pertinência de interpretações e a contemporaneidade das circunstâncias.

"Pode-se resumir Hamlet de diversas maneiras: fazer dele uma crônica histórica, um romance policial ou um drama filosófico. Seguramente serão três peças diferentes, embora Shakespeare tenha escrito todas as três. Mas, se resumirmos bem, o roteiro dessas três peças será idêntico. Com a única diferença de que a cada vez serão uma outra Ofélia, um outro Hamlet e um outro Laertes que farão os papéis. Os papéis são os mesmos, mas representados por diferentes personagens. ${ }^{\prime 37}$

O autor prossegue em sua análise e tudo ficaria na mesma, já que montar Hamlet não era um objetivo, se mais adiante não tivesse sido lançada uma informação que acionou novamente a máquina de associar.

"Hamlet é o drama das situações impostas. E é nisso justamente que reside a chave da sua compreensão moderna" ${ }^{38}$

Esta é uma afirmação decisiva para qualquer um que esteja procurando uma forma de trazer Hamlet para a contemporaneidade. A modernidade prima pelas situações impostas cotidianamente, com o agravante do tempo reduzido para que desempenhemos todos os papéis que esperam de nós. Quais são as pessoas ou situações que se impõem de forma que não podemos escapar?

- As necessidades físicas se impõem - fome, sede, sono, sexo.

- Os papéis sociais - quem sou eu dentro do meu grupo.

- As obrigações - filha, mãe, esposa, profissional.

- As normas de conduta - moral, valores.

- O destino - as circunstâncias imprevistas que nos afetam, às vezes de forma insustentável.

\footnotetext{
${ }^{37}$ Shakespeare nosso contemporâneo Jan Kott p. 75

${ }^{38}$ Ibidem., p. 78
} 
Algumas novas referências imagéticas puderam ser acrescentadas à lista, partindo da idéia de se estar preso a um papel do qual não se pode escapar. De todas essas o destino, amplamente explorado na literatura e no nosso imaginário, foi o que mais interessou. Afinal, ele intimida,afeta e interessa a todos. E existem aqueles que parecem conhecer os caminhos para desvendá-lo. Esse pensamento uniu-se imediatamente à metamorfose da pequena Ofélia acompanhada de perto por Clarice, que sabia o que precisava acontecer; à estranha Cathy, que sabia iludir e determinava destinos, e à Gertrudes que, na visão que estava sendo tomada como ponto de partida, era a detentora de um conhecimento secreto.

Muitos personagens revelam o destino: profetas e suas profecias, sacerdotes em diálogos com os deuses, videntes, bruxas e ciganos com seus instrumentos mágicos e de adivinhação, médicos em diagnósticos e mães com corações intuitivos. A opção pela figura da cartomante foi feita por experiências em brincadeiras de adolescência que se tornaram um hábito e um interesse.

A leitura da sorte traz em si um envolvente jogo cênico porque a pessoa que está lendo precisa de um tempo para ordenar os símbolos que surgem na virada das cartas com coerência. Esse tempo é necessário porque os próprios significados das cartas são abertos e a formação de sentido precisa de alguns segundos para ser firmada ${ }^{39}$. A leitura de sorte é um jogo dinâmico porque impõe ao adivinho uma ação criativa de seleção e ordenação de significância no exato momento de sua execução. As pausas que o vidente faz para dar tempo a essa ordenação interna, esse espaço que ocorre enquanto a intuição trabalha para localizar a resposta "certa" (sempre pensando em termos de organização coerente) constroem uma tensão entre leitor e espectador que pode chegar a ser verdadeiramente dramática.

A adivinhação utiliza símbolos que são flexíveis o suficiente para que o espectador organize sua própria forma significante com os dados que lhe estão sendo transmitidos pela simples ação de ver a carta. ${ }^{40}$ Ele é, portanto, capaz de caminhar entre os fatos do futuro e atingir seu próprio clímax através da sua interpretação particular das formas que o adivinho está lhe fornecendo. O espectador pode sofrer intensamente, sentir-se em perigo ou se alegrar

\footnotetext{
${ }^{39}$ Por exemplo, um ás de espadas pode significar morte, fim de alguma situação, renovação, pausa, inversão de sentido. De acordo com a posição em que esta carta surge em relação às demais o significado é alterado. ${ }^{40} \mathrm{O}$ impacto de ver símbolos que não lhe são absolutamente indiferentes (dificilmente uma carta cheia de corações seria relacionada a uma situação desagradável) e ouvir revelações de uma pessoa que domina um conhecimento secreto oferece ao leitor um número suficiente de elementos para que elabore uma forma completa.
} 
sem que o leitor esteja realmente dando dados objetivos. O espectador da leitura de sorte recria a obra do adivinho no momento em que a recebe num processo análogo ao que se dá na interpretação da obra de arte. Ainda que o artista dê sinais claros da estrutura que construiu (colocando indicações ou símbolos de domínio comum), no momento da recepção o espectador irá conectar os elementos da obra ao seu repertório e a reordenação, total ou parcial, é inevitável.

Como o elemento "conhecimento secreto" já constava entre os que foram considerados adequados ao contexto que se estava delineando, a cartomancia foi incorporada como parte desta obra em processo. Fazia-se necessária a ordenação de uma primeira forma com os itens que seriam utilizados no processo criativo para apresentá-los ao restante do grupo. Como já foi mencionado, a linearidade de uma narrativa não era uma organização desejável naquele momento, sendo a justaposição e sobreposição de estímulos uma formação mais atraente e que revelou-se mais condizente com a natureza dos procedimentos que estão sendo estudados.

Como resultado dessa fase destinada à seleção dos estímulos que serão utilizados na construção da cena foi apresentada a seguinte configuração ${ }^{41}$ :

1. Cadeira vazia diante do espaço de projeção das imagens referenciais. Mesa com um baralho envolto em um lenço preto e um branco. Copo com café frio sem açúcar. Livro Os treze melhores contos de amor. Corda enrolada na cadeira. Platéia postada a cerca de três metros da cadeira em semi-círculo.

2. Projeção de "data show" com apresentação do "power point" iniciada com o quadro Puberdade tomando quase que toda a dimensão da parede ao fundo da sala, de modo a perceber-se imagem e personagem conjuntamente, mas sem interferência demasiada. As imagens vão se sucedendo a cada 30 segundos.

3. Entra a personagem de preto e senta-se na mesma posição da referência, Olha a platéia.

4. Pega o livro e procura pela página.

41 ilustração 2 - performance Hamlet 
5. Inicia a leitura do conto "O amor acaba" de forma neutra diferenciando tempos de pausa para ponto, ponto e vírgula e vírgula.

6. Recoloca o livro na mesa. Bebe o café lentamente, sentindo com atenção o líquido desagradável preencher o espaço da boca e descer pela garganta.

7. Um colega do grupo liga o aparelho de som que vai permanecer tocando as músicas selecionadas durante todo o resto da cena.

8. Pega o volume do baralho e retira-o de dentro dos lenços, recolocando-o sobre a mesa.

9. Pega o lenço preto, segura-o aberto com as duas mãos, cobre os pés com ele e vai lentamente trazendo-o por sobre todo o corpo até cobrir a cabeça com ele.

10. Retoma o baralho nas mãos juntamente com o lenço branco e encaminha-se até o primeiro espectador à sua esquerda.

11. Cobre a cabeça do espectador com o véu branco, beija sua mão, pede que ele tire uma carta do baralho.

12. Coloca a carta escolhida ao centro e tira pela ordem do baralho mais oito que são distribuídas ao redor da primeira formando com ela uma cruz e um X sobrepostos. Procede uma leitura de sorte. Ao final de cada leitura beija a testa do espectador e retira o véu.

13. Ao final da "sessão" retorna à mesa, deposita baralho e os dois véus.

14. Pega a corda que está no encosto da cadeira e oferece-a ao público, deixando-a cair no chão.

É importante perceber que duas características principais se destacavam nessa primeira performance:

$1^{\mathrm{a}}$ A não linearidade. Estímulos se sobrepunham e se relacionavam como num caleidoscópio mutável de dados que deviam ser organizados pela platéia, que não estava recebendo uma história, mas um aglomerado de estímulos a serem ordenados numa forma coerente. 
$2^{\mathrm{a}}$ As ordenações não foram estabelecidas segundo um critério de causa e efeito, mas enquanto fragmentos completos, detentores de conceitos intrínsecos que deviam ser absorvidos na sua totalidade e na relação específica em que se apresentavam. Estávamos, portanto, tratando de uma composição com o predomínio das relações de campo, com elementos que se influenciam mutuamente no ato da sua percepção e nessa influência determinam os significados que serão absorvidos e refeitos pelos espectadores ${ }^{42}$.

Esse primeiro material bruto agradou ao grupo de pesquisa. Os comentários giraram em torno da simplicidade da organização e as sensações recebidas pelo público diante dos múltiplos elementos: a imagem duplicada do início (personagem x projeção), a fala se conjugando às imagens e formando sentidos, o rosto coberto que beijava outro igual e oposto, o sussurro da leitura que instigava os demais observadores que não estavam sendo atendidos no momento, a estranha sensação de ter a sua sorte lida sem pedir (é verdade ou não?), a curiosidade e o medo ao mesmo tempo. Os presentes relataram que vários espaços foram criados: de solidão (bar), de mistério (rosto coberto e leitura da sorte), de tirania (corda e café amargo). A composição foi avaliada como rica em possibilidades a serem exploradas.

\section{A PARCERIA}

A atriz Renata Vendramin, colaboradora do grupo e parceira de projetos anteriores, mostrou-se interessada pelos elementos propostos nesta primeira demonstração, por virem de encontro a questionamentos que lhe interessavam mais especificamente ${ }^{43}$, particularmente

\footnotetext{
${ }^{42}$ Fayga Ostrower distingue duas categorias básicas de ordenação: de grupo e de campo.

Graças às ordenações de grupo somos apresentados a relações de analogia e de contraste o que nos proporciona sensações de ritmo e atmosfera, revela-nos protagonistas dentro de contextos e possibilita-nos entender a narrativa proposta pelo artista no seu diálogo com suas referências e com a materialidade que utilizou na composição da sua obra. Percebemos ápices e desfechos. E é nessa nova relação que se estabelece com o espectador que a obra se completa.

Pelas ordenações de campo atribuímos um significado elaborado para uma forma de complexas relações que se dimensiona precisamente nessas complexidades, única e inalterável porque, se um único elemento desse contexto for substituído ele não permanecerá o mesmo "com uma diferença". Qualquer mudança revelará uma nova forma com novas ordenações em si mesma, as quais se conectarão a nós por uma outra estrutura de referências. A cada alteração surgirão qualidades novas resultantes das especificidades estruturais da nova configuração que se estabelece. O todo qualifica sua existência na dinâmica estrutural que o define.

${ }^{43}$ Renata tem grande interesse pela linguagem cinematográfica.
} 
pelos diversos enquadramentos que podiam ser percebidos nessa primeira composição ${ }^{44}$. Trocamos nossos textos e imagens de referência, enviamos e-mails expondo impressões e avaliamos o material uma da outra.

$\mathrm{O}$ artista plástico trabalha com um objeto que é, em princípio, imóvel. Isso lhe permite deter-se mais demoradamente em cada detalhe da sua obra e delineá-la com precisão. $\mathrm{O}$ tempo que o observador possui para perceber minúcias numa pintura ou escultura pode também ser mais longo do que quando está diante de uma obra que apresenta variabilidade temporal como é o caso da dança, da música e do teatro. A percepção do detalhe no evento teatral é, portanto, uma questão que impõe procedimentos específicos e pede estudos mais aprofundados. Um tema atraente acrescentado ao trabalho em dupla oriundo do repertório pessoal de cinema que agora se oferecia.

No cinema o direcionamento do olhar do espectador é dado pelo diretor. Como o filme é composto de quadros percebidos em alta velocidade, existe uma proximidade de pensamento com a estruturação de obras pictóricas observável nas soluções de enquadramento e movimentos de câmera. Esse parentesco entre as duas linguagens foi estimulante para nós e uma associação de repertórios se concretizou na parceria para a produção de uma única cena.

Renata trouxe como performance preparatória as suas reflexões pessoais sobre o texto de Kott, que também giravam em torno da questão dos papéis impostos e suas idéias acerca da força que impele os personagens de Hamlet à ação, que parece sempre estar associado a graus de loucura. Expôs também suas referências que consistiam em contos de Marina Colasanti, com os quais já havia desenvolvido um trabalho anterior, e algumas produções cinematográficas que, inclusive, traziam trilhas sonoras interessantes com uma tendência minimalista. Dentre os textos de Marina Colasanti terminamos por selecionar dois: Prova de amor e Honra passada a limpo (anexo 5 p. 122) Ambos os textos falavam de desilusão com o amor e papéis impostos. O primeiro também trazia implícito um misterioso conhecimento que nos é revelado sem que consigamos dominar seus mistérios. Os textos de Lygia e Clarice foram mantidos sendo acrescidas algumas relações estabelecidas por Renata:

\footnotetext{
${ }^{44}$ A passagem do plano geral (corpo da personagem incluindo projeções) para o plano detalhe (movimentos isolados das mãos, dos pés durante a leitura do texto e a proximidade da cartomante que se colocava em contato físico com a platéia).
} 
- A descoberta do amor incondicional ao pinto e o assassinato que se dá logo após o encanto. Quanto tempo suportamos o amor dentro de nós? (Legião estrangeira)

Quanto à cena de Hamlet com a mãe:

- Quem é Gertrudes?

- Para preservar a honra feminina ela precisa interpretar papéis.

- Alguém que troca um amor acabado por outro.

- A loucura da perda faz com que ela case de novo com o amor disponível que garante a manutenção da honra e poder.

- As relações da perda estabelecidas sob a ótica de Ofélia, uma personagem mais jovem e inexperiente.

Em todas as discussões que tivemos um ponto permaneceu sempre, e foi decisivo na formatação final da cena: tudo parecia girar em torno da aceitação ou recusa de uma situação imposta. Essas duas formas de se relacionar com um fato, bom ou ruim, mostravam-se decisivas no estabelecimento das situações dramáticas que reconhecíamos ou criávamos por nós mesmas.

Entre as referências cinematográficas trazidas a que afetou mais fortemente nosso

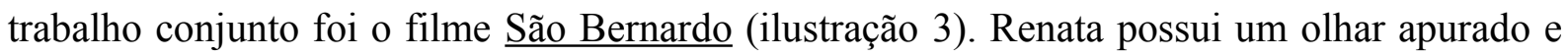
sensível, tendo claros aspectos importantes desse que é o seu objeto particular de estudo ela levantou uma série deles que aproximava nossos repertórios.

- A obra explora característica épicas na sua configuração, pois as idéias de Brecht eram muito bem quistas entre os diretores do período.

- Nela o espectador é convidado a estar presente como observador.

- Uma narração em "off" acompanha a maior parte das cenas, apresentando os pensamentos e conflitos do personagem não em tempo presente, onde se dá a ação, mas num passado que torna o observador reflexivo e onisciente. 
- O texto não é ilustrado pela ação, mas a reforça, complementa e esclarece.

- O tempo para a fixação e análise das imagens fornecidas é muito maior do que o habitual dando ao filme uma qualidade acentuadamente pictórica.

- As estruturas de composição da imagem e seus signos ficam mais evidentes graças às tomadas longas e imóveis, levando à saturação do sentido inicial e conduzindo a percepção do espectador a elaborar outros sentidos na relação figura/fundo, personagem/contexto, voz/imagem.

- As cenas desta produção nem sempre são narrativas, pois as mudanças da visualidade não necessariamente moviam a ação dramática. Era a palavra narrada a real condutora da ação.

Como objeto de pesquisa a ser incorporado ao nosso "caldeirão" selecionamos a cena do quarto onde vemos o casal formado por Paulo (Othon Bastos) e Madalena (Isabel Ribeiro) deitados na cama em seu quarto. ${ }^{45}$

\section{TRAÇANDO NOVOS OBJETIVOS}

Tendo finalmente definidos os estímulos conjuntos para essa obra "a quatro mãos", passamos à fase de experimentação do material a fim de testar as conexões viáveis. Como nos avisa Fayga, cada elemento formador de uma obra possui suas variáveis que devem ser dominadas pelo artista que delas pretende fazer uso. Vejamos um exemplo oriundo das artes plásticas.

\footnotetext{
45 É noite e Paulo atravessa uma crise de ciúmes. As sombras do quarto são densas e diluem as formas dos corpos e da cama. Os personagens trocam de posição ao longo da cena, compondo relações de aproximação e rejeição. A intimidade e proximidade da câmera é tanta que cria uma sensação de continuidade entre o ambiente externo do quarto e interno dos pensamentos da personagem. A distância reduzida e o tempo prolongado da cena permitem ao observador a percepção e exploração do detalhe.
} 
Um pintor utiliza na elaboração da sua obra diversos materiais e fatores que podem se combinar em formas diversas, das quais selecionará uma para assinar e emoldurar.

- Ele deve ter pleno domínio das suas mãos. Conhecer a pressão que exercem sobre o suporte e a força que devem aplicar nos instrumentos. Precisa perceber os movimentos adequados para obter os efeitos que tenciona e ter controle sobre o percurso que será por elas percorrido para não danificar o trabalho.

- Seus olhos devem ser sensíveis às sutilezas que podem ser expressas numa obra e conhecerem os caminhos para alcançá-las.

- É preciso avaliar as características do suporte. Quais as dimensões possíveis e tintas adequadas? Existem texturas? Devem ser aproveitadas ou ocultadas?

- Como se comporta a tinta escolhida? Qual sua viscosidade? Seus solventes? Sua gama de cores? Seu brilho final? Permite trabalhos demorados ou requer rapidez e objetividade no seu uso? Em caso de erro, correções são possíveis?

- Entre os pincéis quais os mais adequados para cada efeito buscado? Existem outros instrumentos possíveis?

- Como o tema será tratado? O que deve ser destacado? Quais os melhores recursos para equilibrar a composição?

O trabalho do ator também tem variáveis, princípios que devem ser observados durante a composição da sua obra para atingir os resultados buscados. O encaminhamento dado a cada um deles dependerá das escolhas que o artista for fazendo, suas preferências estéticas e objetivos comunicativos. Para o professor Armando o artista da cena deve estar atento às seguintes características do seu ofício:

- O ator é uma escultura que se movimenta, o que leva público a perceber o seu movimento como uma dança qualidades escolhidas e dominadas.

- $\mathrm{O}$ ator faz uso em cena de micro-movimentos (como a respiração) que são percebidos e afetam a recepção do todo. 
- Sua voz possui qualidades da música como tonalidade, intensidade e ritmo, e não se restringindo a mero emissor de mensagem textual.

- Em contrapartida, o texto é transmitido por um corpo inteiro, não somente pelo som da voz.

- O silêncio é elemento significativo dentro da composição da cena.

- Toda a sua ação destina-se a ser vista e, por essa razão, deve ser realizada com consciência da presença de terceiros.

- A percepção do público é ativa e interfere diretamente sobre a concepção e a execução da interpretação.

- Já que o teatro produz uma obra múltipla, onde elementos de natureza tão diversa e completos na sua individualidade se unem numa forma que deve possuir sua coerência, tudo tem que estar rigorosamente na medida certa. Portanto, é necessário repetir exaustivamente o detalhamento de cada ação para ter absoluto controle e consciência do seu desempenho.

Tínhamos um longo caminho a percorrer e um material farto a ser investigado. Ao longo do processo nossa rotina mantinha três momentos que se repetiam sempre: o aquecimento, uma prática que concordávamos ser essencial, a experimentação através de princípios análogos aos do contato improvisação (contribuição específica da experiência de Renata) e a busca de soluções para os problemas de interpretação e dramaturgia na variação de composição segundo as idéias de Fayga. 


\title{
2.
}

\section{OS INSTRUMENTOS DE TRABALHO}

\author{
A NECESSIDADE DE AQUECER
}

O professor Januzelli, uma das nossas maiores referências pessoais nos procedimentos que envolvem o treinamento e o processo criativo do ator, dá grande valor ao momento do aquecimento para o trabalho teatral. Segundo ele, existe um período preparatório que antecede todas as ações e fatos importantes na vida do ser humano: a pulsação acelera o fluxo sanguíneo para a luta ou para a fuga quando se percebe a iminência do perigo, o corpo se umedece ou dilata para o sexo, atravessamos meses de intensos preparativos para o casamento ou o nascimento de um filho, antecipamos as necessidades de um encontro ou reunião. Por esse mesmo princípio precisamos nos preparar para a cena, pois é um evento para o qual acionaremos mecanismos que exigirão de nós um grande gasto de energia.

Isso se deve ao fato de que na criação artística para a cena o artista utiliza todos os aspectos do seu ser enquanto veículo expressivo consciente e em constante relação com o espaço e os parceiros de produção. O ator conquista para si, ao longo do aprendizado e de toda uma vida de trabalho, um corpo de percepção e reação refinadas, onde a transparência e a incandescência são ao mesmo tempo os maiores objetivos e trunfos. Esse corpo dilatado em 
consciência é destinado à cena porque a manutenção de tal estado em contexto corriqueiro seria insustentável. Que seria de nós se tivéssemos que nos manter atentos durante dias seguidos a toda a imensa quantidade de mensagens e interlocutores com os quais entramos em contato diariamente? Seria insuportável! Mas essa atenção e intensidade são indispensáveis quando se trata de estar sobre o palco.

O que caracteriza um aquecimento no sentido tratado pelo ator é a atenção dada a essa ação, tornando-a quase como um ritual. Os procedimentos que envolvem essa preparação para o ofício são muitos e variados, não estando limitados a alongamentos e exercícios aeróbicos. Para nosso uso costumamos dividi-los em dois níveis. Numa primeira fase o aquecimento teria a função de desligar o indivíduo da sua rotina e trazê-lo para uma sintonia de produção criativa. É uma espécie de pré-aquecimento, onde acontece uma limpeza do corpo e da mente, e pode dar-se através de atos extremamente simples como é o caso do "laboratório da chegada" do professor Januzelli. ${ }^{46}$

Numa segunda etapa preparatória pode-se agir mais especificamente sobre pontos específicos: exercícios respiratórios, de texto, corporais com ênfases diversas, de visualização, de espaço, de relação. Esse aquecimento dirigido permite a afinação do instrumental do ator e está geralmente voltado para aspectos de interesse (uma dificuldade a ser superada, uma qualidade específica a ser alcançada e mantida durante o espetáculo).

Aquecer é uma prática que faz parte não só da fase de treinamento do ator, quando há muito o que descobrir e muitas habilidades a dominar. Ao longo de toda uma carreira é possível perceber que resultados mais satisfatórios são alcançados por artistas que dedicam um tempo da sua rotina diária, particularmente nos instantes que antecedem a entrada para a cena, à ampliação das suas potencialidades através do aquecimento.

Uma segunda fase de trabalho relacionado a essa sintonização do ator e a obra que ele cria está no estudo de mecanismos que facilitem a sustentação desse estado ampliado, sem permitir a perda de atenção nem da qualidade. Observar-se durante o aquecimento é um

\footnotetext{
${ }^{46}$ Esse exercício consiste na chegada consciente para o ensaio em toda a sua dimensão: o primeiro contato do dia com os colegas, a organização dos seus objetos pessoais, a troca das roupas cotidianas por outras mais adequadas para o trabalho. Todos esses procedimentos preparam o artista para a atividade que se seguirá, desligando-o pouco a pouco das suas preocupações diárias e auxiliando-o a canalizar sua atenção para uma nova ordem.
} 
procedimento de grande valia para o amadurecimento e domínio dessa preciosa habilidade de conservar aceso o fogo divino da criação.

Finalmente, depois de percorridas essas duas etapas, é de suma importância proceder ao desaquecimento para recolocar o ator na sua disposição cotidiana, permitindo o retorno à vida e às relações normais filtradas pela percepção comum. Esse é um ato de respeito por si mesmo e pela experiência vivida na cena. Cortes abruptos da ação e da atenção podem ser extremamente desconfortáveis, além de dificultarem a percepção consciente das transformações pelas quais se está passando.

Os aquecimentos que foram estabelecidos em caráter permanente não foram trazidos desde o início da nossa pesquisa juntas. Eles foram sendo recuperados e adaptados às dificuldades que se mostraram ao longo do trabalho. Assim, quando percebíamos que não estávamos alcançando a esperada qualidade retomávamos ou trazíamos num encontro seguinte propostas de preparo que nos auxiliassem ${ }^{47}$. Experimentamos uma série de ações preparatórias até chegarmos a um roteiro de aquecimento que se mostrou eficiente em todos os aspectos, e passamos a repeti-lo sempre, com pequenas variações ou acréscimos.

\section{O CONTATO IMPROVISAÇÃO}

Segundo Raquel Ornellas ${ }^{48}$, reconhece-se no Contato Improvisação a presença de valores contemporâneos ao momento histórico do seu surgimento como o sentido comunitário e igualitário, a ausência de hierarquia, o espírito de cooperação e a valorização da espontaneidade - fatores que possibilitaram o desenvolvimento dessa prática por pessoas sem conhecimento técnico em dança e que estimularam Steve Paxton, o criador dessa técnica, a afastar-se das companhias de dança moderna que integrou e constituir seu próprio grupo de

\footnotetext{
${ }^{47}$ Por exemplo, quando consideramos nossas personagens tinham uma fonte de força no ventre (Gertrudes enquanto mãe, que exerceu e conhece a força de dar a vida, e Ofélia vendo afastar-se de si essa mesma força vital na negação do amor de Hamlet) passamos a fazer um procedimento que consistia em tentar andar, tendo a parceira firmemente agarrada ao quadril. $\mathrm{O}$ ato de gerar força mecânica a partir dessa região do corpo nos dava uma qualidade de interpretação diferente das vezes em que aquecíamos com exercícios de velocidade, queda ou outros tipos de movimento iniciados em partes diferentes do corpo.

${ }^{48}$ Atriz, Mestra em Artes e praticante de Contato Improvisação, técnica que utiliza na construção de seus espetáculos.
} 
pesquisa. Essa mesma postura que tirava a expressão artística do "cume do Olimpo", inalcançável aos pobres mortais ou aos materiais considerados menos nobres, era defendida por mais artistas da época como é o caso dos dadaístas. ${ }^{49}$

Algumas características que são apontadas por Ornellas como marcantes dentro do Contato Improvisação são:

- A prática em duplas (ainda que eventualmente possam ser realizadas ações com grupos maiores).

- O silêncio durante as performances.

- O intenso e quase permanente contato físico entre os dançarinos.

- A utilização do improviso como diretriz da atividade, eliminando a necessidade de um diretor ou coreógrafo.

- A constante troca de peso, enquanto dinâmica de equilíbrio e desequilíbrio, determinando a fluência do movimento.

- A utilização de rolamentos, deslizamentos, suspensões e quedas.

- A aceitação plena das intervenções do parceiro sobre o próprio movimento.

- A ausência de preocupações dos dançarinos com questões coreográficas ou com produção de imagens.

- Foco interno, ou seja, atenção voltada para a percepção do próprio movimento na relação com o parceiro.

- Destaque à percepção sensorial através do toque, relegando a visão e a audição à posição de coadjuvantes.

Essa é portanto uma expressão que impõe ao artista uma atitude de generosidade e respeito aos próprios limites e às limitações do parceiro, além de exigir que a atenção de ambos permaneça voltada para o encontro que está ocorrendo entre eles naquele preciso momento.

\footnotetext{
${ }^{49}$ O Dadaísmo foi um movimento literário e artístico que renegava a arte institucionalizada por considerá-la produto de uma sociedade "podre". Entre as atitudes que definiam esse grupo estavam o apreço pelo acaso enquanto ferramenta artística e a colocação de objetos cotidianos na posição de obras de arte, como é o caso do célebre urinol de Marcel Duchamp.
} 
"Dançar contato improvisação vai significar um exercício de aceitação das coisas que acontecem e não a tentativa de uma condução delas. ",50

Apesar de esta não almejar objetivos relativos à dramatização, existem artistas do teatro que fazem uso dessa técnica, não só no que se refere ao preparo para a atuação, mas também enquanto material de composição da cena.

Ornellas aponta os seguintes benefícios do uso do Contato Improvisação para o trabalho teatral:

- Possibilidades de se lidar com o acaso.

- Controle da ansiedade

- Relacionamento mais fácil com o sentimento de vazio

- Ampliação de seus conceitos básicos para outras áreas da atuação (como a improvisação vocal)

- Retomada do lúdico teatral.

- Cumplicidade, escuta, cooperação, visão periférica.

Renata freqüentou uma oficina de Contato Improvisação e trouxe os princípios dessa prática. No início do nosso trabalho fizemos uso do Contato para construir a cena e encontrar soluções de problemas cênicos. Quando estávamos insatisfeitas com a qualidade da relação que acontecia entre nós, dançávamos novamente o Contato recuperando os estímulos sonoros que havíamos selecionado. Fomos nos afastando dessa técnica na medida em que queríamos ampliar o espaço e ressaltar a idéia de contraste entre nós.

"Em relação ao contato improvisação, pode ajudar sim na criação de imagens. A tensão que a dança sugere é ótima, a escuta que é preciso ter do outro senão a coisa não flui, alguém bloqueia, um começa a dominar e simplesmente a usar o outro como apoio. Mas se um dá apoio o outro pode voar. Os dois precisam estar presentes, escutando uma ao outro, sem dominações, sem querer dominar, é um jogo de concessões, de respeito, se os dois querem mandar ninguém dança e se os dois esperam do outro ninguém dança. O contato também pode ser dançado com objetos. A mesa, por exemplo, cadeira, ou com os próprios espectadores",51

\footnotetext{
${ }^{50}$ Raquel Ornellas - Caldeirão de bruxas - pág. 47

${ }^{51}$ Renata Vendramim por e-mail enviado em 11/05/2007.
} 
O conhecimento em plástica e história da arte trouxe alguns benefícios extras para nossa pesquisa, particularmente no que diz respeito ao reconhecimento das características que se mostravam mais articuláveis dentre as inúmeras possíveis de se estudar a partir dos estímulos selecionados.

As artes visuais têm lá suas vantagens enquanto processo criativo - elas são expressões estáticas que possibilitam uma reflexão durante a sua construção e uma análise fácil do resultado que, para começo de conversa, não se mexe. Enquanto formas artísticas não subjugadas à existência no tempo, exceto pelo aspecto da sua conservação, tanto o artista na sua produção, quanto o observador na sua contemplação, podem refletir detidamente e sem pressa sobre todos os seus elementos formadores. Essa qualidade torna relativamente simples a compreensão através dela de certos conceitos que também pertencem às outras expressões.

A relação do observador não especializado com a obra de arte traz para o primeiro uma situação inicial de grande insegurança, além de certa frustração ocasional quando a falta de prática ou de algum tipo de conhecimento prévio que pudesse esclarecer dúvidas e auxiliar no entendimento impedem uma relação fácil com a obra observada.

Através de Mariela Mielzynska Kantor, tive a oportunidade de descobrir e exercitar um olhar despreocupado sobre a arte, ainda que absolutamente comprometido com a coerência de idéias. As idéias de Fayga Ostrower assumiram uma nova dimensão quando apreciadas sob a dinâmica dos procedimentos didáticos de Mariela, porque ela exercitava em nós a confiança de externar as conexões que estabelecíamos espontaneamente com uma obra além de também indicar cinco direcionamentos básicos: 
1. Representação - onde fazíamos uma descrição do que podíamos reconhecer num primeiro exame, tratando-se de obras figurativas ou abstratas.

2. Significado - uma verificação livre da imagem fazendo as primeiras associações a outras possibilidades sensoriais (tato, audição, paladar) ou realizando interpretações baseadas em relações de causa e efeito, cultura, sociedade, espiritualidade ou qualquer outra ligação que nosso repertório permitisse.

3. Cores - o reconhecimento do material cromático utilizado pelo artista, a dinâmica da sua distribuição no espaço da tela e o diálogo estabelecido com os efeitos de luz.

4. Composição - a divisão básica da obra em eixos que determinam planos.

5. Geometria - a identificação das demais formas estruturais que podem ser encontradas na composição bem como a sua distribuição no espaço e as relações que entre elas se estabelecem gerando forças condutoras do olhar.

A repetição constante desse procedimento determinou o aprimoramento de uma habilidade que tornou-se confortável o suficiente para ser usada como técnica de aproximação com obras de outra natureza.

Utilizamos em nossa pesquisa uma classificação que servia às nossas necessidades, segundo a qual os princípios básicos da composição plástica estão distribuídos em três grandes temas:

1. equilíbrio - que aborda questões referentes ao uso do espaço, tensão, simetria, e peso perceptível.

2. Configuração - que trabalha as articulações possíveis de elementos e fenômenos.

3. Intensidade - que faz uso da luz, cor, ritmo e movimento. 
Para cada um desses itens podemos identificar uma serie de variáveis reconhecíveis. Tomemos como exemplo duas aquarelas de Carybé (ilustração 4) e vamos analisá-las segundo a variável espaço.

Um quadro pode ser estruturado, no que diz respeito ao espaço, segundo dois critérios principais: a real bidimensionalidade da tela ou o efeito de tridimensionalidade que pode ser por ela sugerida. Sendo assim, podemos analisar as linhas que se desenham no campo diante de nós no sentido da altura, largura e diagonais (considerando-as como linhas distribuídas num suporte retangular) ou enquanto possibilidades de planos que se sucedem em direção a um fundo imaginário (como se estivéssemos diante de uma janela aberta, também retangular).

A simples percepção dessas linhas pode conduzir a uma série de relações que, tecnicamente corretas ou não, serão suficientemente divertidas para justificarem a sua formulação, além de já estarem reformulando os repertórios do observador em novas conexões significativas.

Por que o artista optou por organizar esses vaqueiros como uma cruz?

Por que esses pescadores, tão absolutamente integrados na paisagem, sem rosto ou detalhes mais civilizatórios do que a sua própria forma humanóide, repetem em tantas situações a mesma linha limpa e firme do horizonte?

Todas as respostas para estas e outras perguntas são corretas enquanto expressão do pensamento e da história pessoal de quem as formular. É o observador elaborando a sua obra no ato criador de ler. O reconhecimento desse "jogo possível” renova no leitor o seu pensamento criador. Para estabelecer essas relações o requisito indispensável é permitir-se certa liberdade de aproximação da obra de arte. A confiança na abordagem da obra torna-se mais consistente na medida em que o observador vai se familiarizando com a produção artística num clima de tranqüilidade e sem a ansiedade imposta por conceitos de certo e errado. Essa disponibilidade em relacionar-se tendo em mente esse campos de ação determinados e estando-se consciente das variáveis envolvidas pode ser estendida à prática teatral na sua especificidade, pois existem equivalências. 
Enquanto possibilidade de abordagem, encontramos nas artes plásticas contribuições em três aspectos distintos da teatralização: no enriquecimento de soluções para a composição da cena, como síntese de sensações ou informações auxiliares que funcionem como estímulo para a construção de cenas e personagens e enquanto proposta de pesquisa para estruturação do corpo numa abordagem da mecânica do movimento. Para este trabalho procuramos concentrar atenção sobre esta última qualidade nas nossas discussões ainda que, de forma indireta, os outros dois aspectos tenham sido intensamente aplicados.

\section{III.}

\section{OS MECANISMOS DA} CRIAÇÃO 


\section{ROTINA DE TRABALHO}

Nosso aquecimento era inicialmente feito separadamente. Cada uma realizava alongamentos, exercícios de força ou velocidade, ou simplesmente relaxava para limpar os detritos do dia antes de colocar-se em cena. Depois de algum tempo percebemos que a colocação da voz dentro do padrão escolhido como referência trazia certas dificuldades e passamos a iniciar o trabalho buscando a adequação com a sonoridade das músicas escolhidas. Mais tarde Renata trouxe para a nossa prática um procedimento que era de seu costume que contribuiu tão positivamente para a nossa produção que passamos a executá-lo sistematicamente $^{52}$. Iniciávamos por uma espécie de massagem auto-aplicada que agia no couro cabeludo, músculos da face, braços e pernas em movimentos que variavam entre pequenos ou grandes círculos, descolamentos fortes ou delicados e movimentos retilíneos no sentido da fibra muscular ou no sentido contrário.

Feita esta primeira etapa passávamos ao procedimento em dupla, uma aplicando a sequência na outra, estabelecido dentro de uma dinâmica que consideramos confortável e eficiente:

1. De pé, pés paralelos, quadril encaixado, abdômen contido, tronco desce relaxando braços e cabeça em direção ao chão. Um trabalho

\footnotetext{
${ }^{52}$ Renata participa do Atelier de Artes e Ofícios, onde é desenvolvido um trabalho voltado para o cinema. Lá ela entrou em contato com os procedimentos de Marcio Mehiel que vem estruturando uma prática que ele denomina "físico-energética". O exercício que nós utilizamos foi trazido de lá.
} 
de percussão com os punhos fechados sobre as proximidades do cóccix, ao longo da coluna até o meio dos músculos dorsais, e diretamente sobre os ísquios.

2. Uma estimulação da circulação com as mãos em garra fazendo uma espécie de varredura em sulcos ao longo das costas, braços e pernas.

3. Uma dá apoio à outra no retorno da coluna e cabeça fazendo pressão sobre o cóccix com uma das mãos, direcionando-o para baixo e para frente e auxiliando o desenrolar progressivo da coluna.

4. As mãos percorriam costas, laterais e frente num gesto de limpeza.

Passávamos então ao aquecimento vocal que percorria cinco etapas relacionando a voz com áreas do corpo e traziam uma organização corporal bem definida. Era emitido o som de uma vogal para cada ponto e buscava-se produzir o som na região que estava sendo visualizada naquele momento e que é associada a Chacras $^{53}$.

Foi graças a esses exercícios que uma certa qualidade de voz pôde ser alcançada e utilizada na cena final.

\begin{tabular}{|l|l|l|l|l|l|l|}
\hline posição & pernas & tronco & braços & cabeça & atenção & Vogal/som \\
\hline
\end{tabular}

\footnotetext{
${ }^{53}$ De acordo com o hinduísmo tântrico existem diversos pontos espalhados pelo corpo que funcionam como centros de energia. Cada um deles corresponde a um órgão interno e a um aspecto da existência humana - desde o instinto de sobrevivência à espiritualidade.
} 


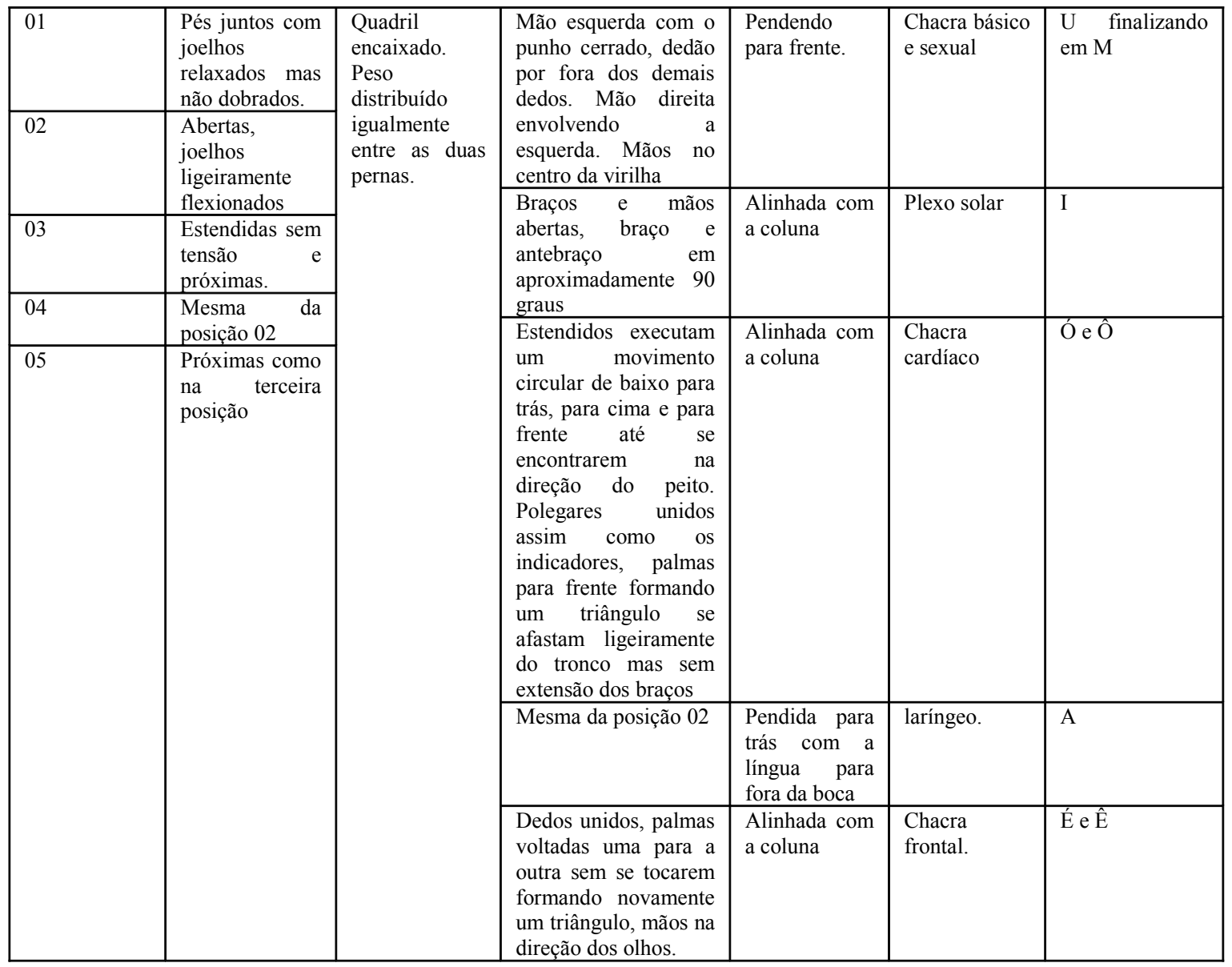

Terminado o procedimento preparatório da voz, tínhamos o hábito de aquecer o corpo dançando ao som de instrumentos de percussão, principalmente no segundo semestre, quando adotamos o derbak ${ }^{54}$ como nosso favorito para essa dinâmica de preparação. $\mathrm{O}$ som age diretamente sobre o sistema nervoso central, e a música instrumental o faz sem filtros racionalizantes que poderiam ser percebidos em canções letradas. Quem não sabe da capacidade que a música tem de levantar ou derrubar uma festa? Do estado a que as pessoas são levadas através da música, por vezes podendo chegar à histeria em massa? A ação da música sobre o ser humano já foi, e ainda é muito analisada, e suas aplicações na cena foram objeto de estudo de muitos dos mais renomados nomes do teatro.

“O primeiro espetáculo do Teatro de Bali, que tem traços de dança, canto, pantomima, música, e muito pouco do teatro psicológico tal como o entendemos aqui na Europa, recoloca o teatro em seu plano de criação autônoma e pura, sob o ângulo da alucinação e do medo". 55

\footnotetext{
${ }^{54}$ Instrumento de percussão típico dos países do Oriente Médio e Egito e que permite uma grande variedade de recursos sonoros. As músicas que trazem o derbak no seu arranjo possuem uma energia vibrante e contagiante.

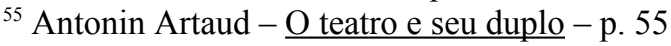


"Tudo isso parece um exorcismo para fazer nossos demônios AFLUÍREM"'56

Os ritos religiosos, profundamente ligados às origens do teatro, sempre envolveram de alguma maneira a encenação e a música na sua prática e na sua mitologia. Existem narrativas que trazem a trindade hindu (Brahma, o criador; Vishnu, o preservador e Shiva, o destruidor) desempenhando seus papéis através da dança. Os hinos católicos do ritual da missa trabalham mais comumente através da transmissão da mensagem, mas, em casos específicos como no canto gregoriano, a sonoridade nos induz a um estado de interiorização semelhante ao que se dá na execução de mantras hinduístas e xintoístas, onde as frases se emendam numa sonoridade contínua e hipnótica. Numa aplicação diferente do som, encontramos nas religiões de origem africana formas construídas para conduzir ao êxtase mediúnico. Isso se dá porque somente um corpo num estado vibracional específico, que pode ser alcançado através da dança, é capaz de alojar uma divindade. Cada entidade possui uma qualidade sonora que a ela se reporta e tem a função de trazer os médiuns ao nível de energia adequado para as qualidades daquele orixá ${ }^{57}$. Dançar é, portanto, uma forma comprovada de atingir estados especiais e apropriados para a criação artística. Além de ser uma delícia.

Nas poucas vezes em que não tivemos tempo ou disciplina de percorrer essas etapas iniciais o rendimento do trabalho era sempre muito abaixo do habitual. Os exercícios rotineiros de aquecimento comprovaram-se como responsáveis por ganhos significativos no rendimento do ensaio, principalmente quando a cena já estava configurada e sabíamos o tipo de energia que queríamos alcançar.

A VOZ

A primeira forma ordenada que obtivemos foi a da conjugação da referência das vozes de Huun Huur Tu e a transferência das suas qualidades monocórdicas, graves e estranhamente

\footnotetext{
${ }^{56}$ Ibid., p. 64

${ }^{57}$ Denominação genérica para as divindades do panteão africano
} 
contínuas para a comunicação do texto "O amor acaba". A primeira ação relacionada à voz foi estabelecer como uma das metas a serem atingidas a apropriação da qualidade vocal da música Legend e a sua transposição para a fala. Concentramo-nos então nas variáveis referentes à verbalização do texto "O amor acaba", pois era o nosso favorito e estávamos de acordo em usá-lo na cena.

Nossa referência musical trazia uma qualidade dual: tínhamos vozes masculinas, graves e de sonoridade gutural em oposição às vozes femininas, agudas e nasaladas. $\mathrm{O}$ masculino era contínuo e sem pausas, encobrindo a respiração e refletindo num desenho que se alterava em linhas suaves que subiam e desciam na imaginação. As sobreposições de vozes pareciam ter o intuito de unificá-las. O feminino também trabalhava com sobreposições, mas traçando desenhos diferentes, formando padrões em arabescos que se alternavam e valorizando pausas, entradas e saídas das vozes. A primeira ação foi justamente tentar encontrar os lugares no nosso que permitiriam uma sonoridade semelhante e acompanhar esses desenhos para arquivá-los em nosso memorial.

Trabalhamos com o som durante vários minutos em diversas ocasiões, buscando trazêlo de partes mais baixas do corpo e lançando o agudo para a metade superior, particularmente garganta e cabeça. Diante de certas dificuldades nesse sentido que se tornaram difíceis de superar, Renata trouxe para a dinâmica diária de aquecimento a série de exercícios para a voz e corpo já detalhada anteriormente.

Além da origem do som, especial nossa atenção à continuidade monótona da música. O texto de Mendes Campos, pela ausência de pontos finais, também trazia essa continuidade na sua forma sobre o papel. Nuances poderiam ser dadas enfatizando certas palavras ou silabas. Ou não. Novamente estávamos às voltas com seleções anunciadas por Fayga, pois não seria possível investigar todas as variáveis que uma única referência trazia. Juntamente com alguns dos elementos de Legend, foram excluídas as questões da música Akh Ti Notchenka pela mesma impossibilidade de analisá-la a contento. Ainda assim, por diversas vezes percebemos nuances, principalmente no movimento, que sabíamos terem surgido a partir da ação de dançar essa referência. Eram repertórios já incorporados e que eram ocasionalmente acionados. 
Quando lemos um texto mentalmente ou pela primeira vez, de forma geral não damos essas entonações próprias da interpretação do sentido. As palavras estão sendo mentalmente decodificadas, mas possuem ainda cores pálidas, estão rasas de conteúdos emocionais que lhe dêem cor ao significado. Essa relação sem intenção ocorre principalmente quando lemos sem sentirmos nenhum tipo de envolvimento pessoal com a informação que estamos recebendo, se estamos indiferentes ao conteúdo do texto. Essa forma de ler, silenciosamente ou em voz alta, é a abordagem que consideramos mais próxima da qualidade sonora da música, e foi nela que concentramos nossos esforços.

O texto foi lido repetidas vezes para que observássemos uma na outra o efeito daquelas palavras sendo pronunciadas, dando-se destaque somente aos sinais de pontuação. Procurando manter o ritmo da leitura constante e confortável para ambas, começamos a experimentar alternar os fôlegos para que pudéssemos ler ora juntas, ora sozinhas. Depois de algumas tentativas chegamos a uma cadência que nos permitia tornar a encher os pulmões sem que o ar da colega ficasse demasiadamente escasso, o que comprometeria a qualidade das palavras.

Até esse momento trabalhávamos com o texto nas mãos para não ocuparmos a mente com a tarefa extra de lembrar as palavras exatas já que, por falarmos em uníssono, erros não seriam possíveis sem o sacrifício do efeito desejado. Executávamos um exercício de escuta que consistia em estar atento aos ritmos e aos fôlegos e, a cada retomada de voz, entrávamos na música que estava sendo produzida pela parceira de modo harmônico e respeitoso. $\mathrm{O}$ respeito estava presente também na velocidade da respiração, pois precisávamos observar os limites do nosso fôlego e estar atentas na recuperação para não deixarmos a parceira em situação desconfortável, tendo o cuidado estético de delimitar espaços onde as duas vozes se sobrepunham em igualdade de condições. Estávamos trabalhando com "contato improvisação sonoro". Foi o primeiro desdobramento de uma técnica já estabelecida que acabamos fazendo para resolver a ordenação dos elementos do nosso interesse. 
Com o passar do tempo o texto foi fixado ${ }^{58}$ e o jogo de fôlego pôde ser mais profundamente examinado, tornando-se mais interessante a cada vez. Esse aprendizado foi estendido a outros momentos da cena que, se não tinham o objetivo de demonstrar essa questão da sobreposição de fôlegos, mantinham as intenções que justificam a colocação da voz numa área mais baixa do corpo. Foram também inseridas experimentações quanto à intensidade da voz e as alterações que essas variações conferiam à percepção da relação e do contexto que foi aos poucos se delineando.

\section{O CORPO NO ESPAÇO}

O trabalho de corpo teve duas diretrizes principais: o contato improvisação e o desdobramento das imagens de referência.

Para iniciarmos a relação cênica decidimos escolher logo de saída um ambiente para abrigar a ação e determinar certa quantidade de objetos que iríamos estudar. Essa decisão fixou mais uma série de limitações que fecharam centenas de possibilidades e mantiveram outras tantas abertas e disponíveis, exatamente como Fayga afirma acontecer em todo processo de criação. Essa atitude deveu-se a duas circunstâncias. A disponibilidade de tempo em comum era ínfima se comparada às condições ideais dentro do trabalho teatral. Não podíamos, por essa razão nos dar ao luxo de dedicar um tempo maior a cada uma das referências, que já eram muitas, e estavam constantemente sendo revistas e peneiradas. Sentimo-nos frustradas por termos de colocar de lado uma série de caminhos atraentes sem investigá-los em profundidade, mas sabemos também que prazos são uma realidade incontestável a que temos de nos submeter. Essa mesma situação tem seu ponto positivo. Num trabalho com menores obrigações com relação a datas existe uma tendência a

\footnotetext{
58 Além de uma oficina de apropriação do texto através da escrita aplicada pela atriz e pesquisadora do grupo Rejane Arruda, um exercício que nos auxiliou muito na retenção do texto foi um jogo que inventamos a partir do manuseio do baralho. Cada um permanecia com um baralho na mão com as figuras voltadas para baixo. Uma de cada vez, íamos virando as cartas e depositando num monte entre as duas. Se a carta virada fosse vermelha (copas ou ouros) Renata dizia uma frase completa do texto. Se surgisse uma carta preta (espadas ou paus) Sandra era responsável por dar seqüência às falas de onde tivessem parado. Com o tempo ganhamos fluência e aumentamos cada vez mais o ritmo do jogo.
} 
permanecer por um tempo demasiado nessa fase tão estimulante das experimentações. Contudo, se a obra não for concluída como avaliar a pertinência de déias e procedimentos.

"Todo processo de criação compõe-se, a rigor, de fatos reais, fatores de elaboração do trabalho, que permitem optar e decidir, pois, repetimos, ao nivel de intenções, nenhuma obra pode ser avaliada. Como obra, ainda não existe. Vale dizer, então, que a criação exige do indivíduo criador que atue. Atue primeiro e produza. Depois, o trabalho poderá ser avaliado com critérios e interpretações.

Mas essa questão da pré-escolha também envolvia outra necessidade. Segundo o pensamento de Ostrower, todas as relações estabelecidas com um estímulo podem resultar em ordenações coerentes se dedicarmos a ela nossa atenção e procedermos a uma investigação consciente e respeitosa das características dos elementos envolvidos. Portanto esta seria uma boa oportunidade de comprovar essa teoria.

No que se refere ao trabalho corporal do ator, uma das questões que nos acompanhava era a da distância entre as características pessoais do ator e o trabalho de interpretação. Reconhecemos enquanto espectadoras a existência de predominâncias conceituais em certos pensamentos que determinavam formas definidas de atuar. Procurávamos por uma maneira que permitisse ao ator uma interpretação sempre renovada, não necessariamente naturalista e construída dentro dos limites da sua individualidade, dispensando longos condicionamentos e estudos demorados de códigos específicos. Para alcançar esse objetivo trabalhamos mesclando o contato improvisação e o estudo da matéria plástica, que no caso eram as possíveis formas de reprodução e desdobramentos das referências imagéticas que havíamos selecionado. Esse procedimento consistia em:

- Estudar detalhadamente o posicionamento dos músculos e ossos das obras escolhidas, que traziam essencialmente representações de corpos humanos. ${ }^{60}$

- Experimentar os desdobramentos possíveis mantendo-se a essência da imagem tais como: variações de plano, caminho percorrido na

\footnotetext{
${ }^{59}$ Fayga Ostrower - Criatividade e processos de criação - p. 71.

${ }^{60}$ É possível construir uma representação física de obras não figurativas, mas a transposição de uma forma abstrata para o corpo requer outras delimitações de critérios para ocorrer (como escolher entre os aspectos cromáticos, de linha ou ritmo) o que torna o processo mais moroso.
} 
sua composição, variações de ritmo e acentuações de partes do movimento, inversões de sentido, interação com objetos ou com o espaço, agregar intenções ou manter-se atento à associação por uma idéia paralela, palavra ou sensação.

- Dançar esse novo vocabulário corporal descoberto em ritmos diversos, mas dando sempre preferência ou insistindo por mais tempo na experimentação sob a influência das referências musicais selecionadas.

- Interagir com a parceira dentro desse novo vocabulário, primeiro mantendo-se fixo no seu próprio desenho corporal, depois deixando-se influenciar pelo da companheira e finalmente alterando-se ambos os desenhos pela ação do contato com a parceira e com o ambiente (no caso, o quarto).

Essa dança executada deve ser experimentada segundo os mesmos desdobramentos que orientam a pesquisa das referências visuais. Sob qualquer uma dessas diretrizes procuramos sempre observar as soluções que nosso corpo, com suas peculiaridades, encontrava para as situações propostas, sem imposições que causassem qualquer tipo de incômodo. Em meio a essas danças, muitas imagens foram se formando e íamos guardando na memória aquilo que conseguíamos perceber como interessante. Estávamos filmando todo o processo desde o começo e tínhamos a intenção de selecionar os elementos através dos registros, mas isso se mostrou inviável, novamente pela falta de tempo. Passamos a confiar na percepção que tínhamos do que estávamos fazendo e só recebíamos um retorno mais objetivo com os comentários do grupo nas apresentações.

As improvisações foram trazendo imagens isoladas ou estabelecidas na relação das duas pesquisadoras. Encontramos ordenações que sugeriam diversas estruturações:

- Aconchego de uma mãe que consola a filha após a perda.

- Uma bronca dada pela mãe na filha que insiste em ficar na fossa.

- Uma irmã que ironiza e debocha do sofrimento da caçula

- Provocações mútuas de naturezas diversas.

- Uma mulher que causa sofrimento a uma outra mais fraca. 
- Uma jovem que renega o sofrimento e uma velha que o aceita.

- Alguém absolutamente indiferente à dor alheia.

Situações indefinidas onde faltava clareza e especificidade. Por vezes as partituras estavam muito satisfatórias e interessantes enquanto movimento, mas quando esses elementos isolados precisavam se ordenar em conjunto com o texto, a voz e o ambiente, pediam mais clareza da relação. Muitas vezes o corpo sentia-se deslocado e desconfortável dentro da relação, não nos sentíamos verdadeiras. Uma solução que o grupo propôs foi radicalizar na proposta de abstração da composição: assumirmos que estávamos realizando um estudo de composição de elementos que não se propunha narrar nenhuma situação. Mas essa resolução não satisfazia a nossa necessidade que nos impunha falar dessas duas maneiras de lidar com a perda que estávamos seguras de serem absolutamente universais.

Após algum tempo, sempre através das improvisações e de discussões acerca do material obtido nesses momentos, algumas qualidades foram se definindo. Possuíamos duas mulheres que representavam qualidades opostas e, por essa razão, mostravam contornos marcadamente diferentes que surgiram a partir dos estudos das imagens, já novamente filtradas, e foram sendo fixadas, agora com atenção para as características que as duas personagens sugeriam a cada uma de nós após repetidas discussões e considerações. Gertrudes resolveu sua questão tocando a vida adiante, Ofélia enlouquece e morre. Parecianos uma associação plausível e não estávamos dispostas ainda a fechar essa relação num título que pudesse ser dado a ela (como mãe e filha, por exemplo). Os corpos foram respondendo a esses estímulos e definições da seguinte forma:

\begin{tabular}{|c|c|c|c|}
\hline Personagem & plano & ritmo & Idéia central \\
\hline $\begin{array}{l}\text { Ofélia } \\
\text { A jovem } \\
\text { A noiva } \\
\text { A menina } \\
\text { A apaixonada }\end{array}$ & Baixo e médio & $\begin{array}{l}\text { Rápido com } \\
\text { quebras violentas } \\
\text { torções para trás }\end{array}$ & $\begin{array}{l}\text { Eu sofro e não } \\
\text { aceito o sofrimento. Não } \\
\text { quero viver isso. }\end{array}$ \\
\hline $\begin{array}{l}\text { Gertrudes } \\
\text { A mãe } \\
\text { A viúva } \\
\text { A escritora } \\
\text { A desiludida }\end{array}$ & Médio e alto & $\begin{array}{l}\text { Lento } \mathrm{e} \\
\text { cadenciado. Com torções } \\
\text { para os lados }\end{array}$ & $\begin{array}{l}\text { Eu } \quad \text { sofri } \\
\text { sofrerei. É } \\
\text { todos. Tudo passa. }\end{array}$ \\
\hline
\end{tabular}


As referências visuais efetivamente trazidas para a partitura corporal utilizadas até então estão no quadro abaixo (ilustração 5). Os negritos foram as que de fato permaneceram, ainda que reestruturadas para as circunstâncias que foram se alterando ao longo do processo.

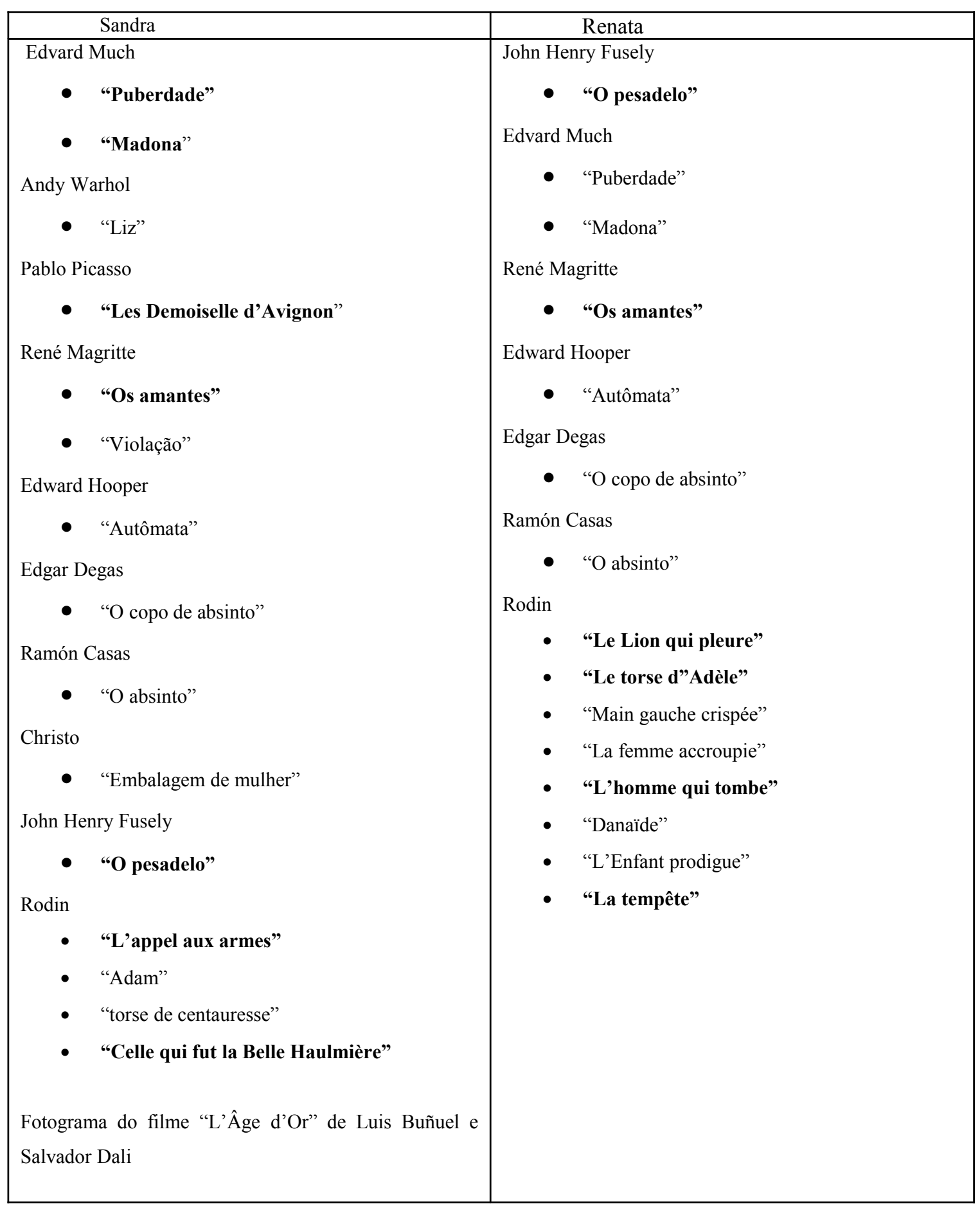


A primeira apresentação em dupla expôs o caminho que estava sendo percorrido, sem nenhum tipo de preocupação em mostrar um resultado formatado. Mantivemos a atenção em demonstrar os temas e relações que investigávamos e algumas amostras dos primeiros resultados de desdobramento dos estudos realizados até o momento. As críticas giraram em torno da imprecisão da natureza da relação dessas duas pessoas que estavam em cena. Ou se criava uma situação dramática precisa, ou se lançava de cabeça na abstração da composição. Voltamos para a sala de ensaio e continuamos a pesquisar.

A próxima apresentação se avizinhava e ainda, não possuíamos um roteiro. Para tentar superar essa deficiência passamos a pensar mais objetivamente com relação à dramaturgia. Consideramos que toda narrativa começa por apresentar os antecedentes de um problema, em seguida acontece uma quebra que modifica a situação trazendo por fim uma solução. Como não conseguíamos definir previamente todas essas informações que estavam faltando, pensamos em utilizar de fato os textos que foram selecionados como referência, trazendo-os para a cena.

Em experiências anteriores já havíamos aprendido que o sentido é realmente estabelecido pelo receptor da mensagem. Em qualquer combinação de palavras a mente irá buscar uma organização. Fizemos então uma nova seleção de fragmentos de todos os textos e os colocamos numa seqüência. Paralelamente a esse arranjo experimentamos uma organização dos elementos que precisariam ser definidos. Procuramos uma forma de ambientar o quarto, que sempre esteve presente no nosso imaginário. Para não corrermos o risco de impor a leitura de uma relação amorosa entre nós duas, buscamos uma organização espacial que remetesse a outro elemento referencial: o baralho. Como não queríamos ainda fixar os fragmentos dos contos experimentamos tratá-los como narração em off, como no

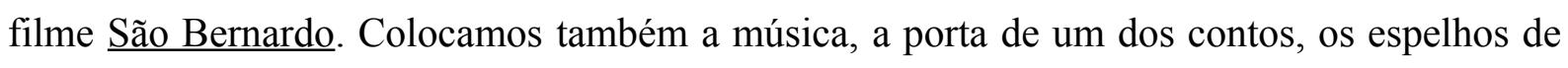
outro (que também serviriam para propor enquadramentos de câmera em planos detalhes), os colares de pérolas, os rostos cobertos e os corpos e vozes que já havíamos encontrado. Todos objetos que estávamos estudando e que, de alguma forma, nos interessavam

Acabamos obtendo uma imensa salada de referenciais descontextualizados, simplesmente transpostos e colados numa sequência que só fazia sentido para nós. Uma 
ordenação, sem dúvida, mas com um número inviável de itens. Isso foi uma reincidência num erro já anteriormente cometido: a utilização de formas ordenadas prontas e não de sínteses essenciais. Essa organização gigantesca foi baseada em conexões externas que eliminaram a possibilidade de leitura das personagens cheias de adereços, mas que continuavam com identidade obscura. Estávamos atravessando nossa segunda e mais intensa crise de criação.

“...nos preocupamos em levantar uma estrutura lógica, coerente para acena, uma sequência de ações e imagens.(...) A preocupação era em dar conta da movimentação dentro de toda aquela estrutura externa. Fiquei simplesmente lidando com toda aquela estrutura, com a maior naturalidade possível naquele momento, mas não tinha intimidade com aquilo tudo. ",61

Para que o espectador seja capaz de se relacionar com uma obra é preciso que sejam deixadas brechas, conexões abertas. Isso só é possível se o artista utilizar uma quantidade de elementos que possam se agrupar em mais de um sentido. O excesso de variáveis requer grande esforço do leitor para processá-las, fazendo com que a percepção filtre somente alguns ítens, diluindo o restante num contexto disforme, uma massa de informações que se transforma numa textura, num ruído que acompanha e interfere na leitura dos focos escolhidos. Outro aspecto dessa mesma questão é que se a fala é reproduzida pela imagem (ou vice-versa, como no nosso caso aconteceu na sobreposição da ação e da voz em “off”) a conexão já está feita de forma dura e incisiva, e o observador fica novamente impedido de se relacionar com a obra, o que provoca a sensação de redundância e estagnação.

É também bastante complicado quando se misturam estímulos de natureza diferente. Como a mente procura a classificação e a ordem, é muito difícil para ela elaborar sentidos a partir de fragmentos que pedem uma organização subjetiva recebendo-os através de uma circunstância interpretada como fisicamente realista. Essa justaposição só seria possível se o objetivo fosse trabalhar com a idéia de contraste e não na situação de uma relação que caminha numa pretensa unicidade.

Uma crítica acentuada foi novamente a da ausência da relação entre as duas. A conexão com a platéia não se estabelecia, os enquadramentos não eram percebidos como tal

\footnotetext{
${ }^{61}$ Renata Vendramin em relatório da apresentação de 19/06.
} 
porque não estavam de fato presentes e não existia uma ação conjunta entre nós no meio de toda aquela "parafernália" construída. Para demonstrar que a simplicidade poderia ajudar, o professor Armando propôs um exercício de escuta. Fomos postas no centro do círculo de discussão, bem próximas do grupo, e recebemos a tarefa de dizer o texto uma para a outra. $\mathrm{O}$ contato improvisação era uma prática já razoavelmente solidificada em nós e o exercício trouxe resultados agradáveis a todos. Tínhamos, portanto, o caminho, mas havíamos nos distanciado dele. Um direcionamento foi também proposto pelo professor Januzelli no sentido da recuperação da conexão entre nós, com alguns objetos que se mostraram interessantes (como as cartas) e com o texto. Novamente a força da relação se mostrou acessível e produtora de vida.

"Um outro corpo - o duplo - vivo, vibrante, com uma tensão justa, que me ajuda a acessar estímulos" ${ }^{\prime 2}$.

Ter alguém para conduzir com mão precisa e generosa acelera todo o processo de forma impressionante, mas não tínhamos esse recurso e só contávamos com nossa percepção e objetividade na avaliação de caminhos, possibilidades e resultados. Os exercícios reforçaram a ação de aterrar o corpo e buscar a energia num centro físico, neste caso no útero - extremamente apropriado para uma cena onde duas mulheres queriam falar de medo, raiva e amor. Percebemos que tínhamos perdido essa atenção e fomos deixando que a mente tomasse novamente a frente. É um hábito difícil de combater. Nossa vida é organizada mentalmente, em estruturas conceituais e orais. Mas, como afirma Fayga Ostrower, a criação em processos de forma é matéria física, não intelectual. Precisávamos novamente incandescer a partir do centro certo e usar essa energia na cena.

\section{O PONTO DE MUTAÇÃO}

Sentamos novamente para avaliar o caminho e planejar as próximas ações. Tomamos como exercício nesse encontro a busca da síntese da idéia em uma única frase ou imagem.

\footnotetext{
${ }^{62}$ Renata Vendramin em relatório de atividades 19/06.
} 
“Fiquei pensando na tal situação dramática , o que seria nosso trabalho então, e lembrei de algumas coisas que já comentamos, mas que a gente acaba perdendo:

- Como São Bernanrdo, a situação dramática se desenrola através da narração, da palavra dita pelo narrador, e as ações apresentadas não têm necessariamente a ver com tudo o que ele diz, e isso é interessante porque não fica ilustrativo, amplia o significado de tudo, o espectador tem espaço para elaborar diferentes interpretações do fato, para perceber coisas que vão além do texto narrado na imagem que vai até a saturação diante dos seus olhos.

- Nossa situação dramática seria então: O amor acaba! Concorda? ",33

Convencidas de que seríamos capazes de comunicar todas as nuances da mensagem apenas com o poema "O amor acaba", a grande pergunta era "O que fica?" Estávamos confiantes na qualidade dos elementos que possuíamos. Tínhamos um problema de ordenação, não de repertório. Era preciso deixar espaços, de leitura e de tempo, para que o espectador pudesse criar e nós nos movimentarmos sem termos excesso de bagagem em que pensar. Depois de muita reflexão tomamos uma série de decisões:

- Utilizar somente o texto "O amor acaba". Os demais seriam mantidos como repertório já adquirido e incorporado, como por exemplo, numa atenção às costas ("procurava manter a dignidade das costas" - Legião estrangeira)

- Filtrar novamente as imagens para que a partitura pudesse se estender mais no tempo, sendo mais facilmente percebida pelo observador e desocupando o executor.

- Manter somente um elemento de ambiente selecionado. Elegemos a cama e, durante as improvisações ela também teve seus desdobramentos. Estabelecemos também que o baralho teria sua importância ampliada numa tentativa de aumentar a importância desse conhecimento secreto. Optamos por trazê-lo para a cena desde o seu início, mantendo-o à vista do público o tempo todo como um signo a ser compreendido.

\footnotetext{
${ }^{63}$ Renata Vendramin por e-mail do dia 21/06/07
} 
- Fechar a intenção definindo uma frase título: as duas formas de se lidar com o fim do amor: aceitar ou revolta-se. (A honra passada a limpo, As pérolas).

- Estabelecer a relação dramática na oposição de mestre e aprendiz, entre as muitas possíveis, para representar uma experiência dolorosa que já foi vivida por alguém e está sendo experimentada por outro. Essa decisão foi tomada por ser uma forma que se relaciona com todas as outras dualidades levantadas e por trazer em si a sugestão do conhecimento secreto que será transmitido, além de rever a questão da metamorfose (Legião Estrangeira, Prova de amor). Estava, portanto, definida a nossa cena como "um rito de iniciação"

- Trazer a voz de baixo e fazê-la acompanhar a ação.

- Manter e reforçar a atmosfera de sagrado (o amor, a morte, o conhecimento oculto, a previsão do futuro) na tentativa de envolver a platéia - enquanto ação e sensação. Nos ritos a assembléia participa ativamente acompanhando tudo e venerando as metamorfoses (a incorporação do médium, a transmutação do pão e vinho em corpo e sangue de Cristo). Em algum momento ela se beneficia do rito (passe, comunhão, consulta, benção) e age dando a sua contribuição (cânticos, oferendas). Estávamos, assim, determinadas a transformar uma desilusão amorosa num rito de iniciação sobre o palco.

- A opção pela circularidade ${ }^{64}$ por várias razões: pelo simbolismo que carrega $^{65}$, pela consciência ${ }^{66}$ que exige do ator de si mesmo e do espaço que o circunda, e pela participação do público, uma resposta cada vez mais comum do teatro moderno ao crescente isolamento que o ser humano está se impondo.

\footnotetext{
64 Essa circularidade surgiu também das próprias referências imagéticas, na sua maioria esculturas, que são pensadas para serem vistas por todos os ângulos, um desafio estimulante para o ator que precisa de toda a sua consciência alerta no corpo, no momento presente e na relação com o parceiro, o espaço e o público.

${ }^{65}$ Ciclo, recomeço, permanência, eternidade

${ }^{66}$ Para que essa consciência em cena acontecesse, uma grande contribuição foi da atriz e pesquisadora do grupo Flavia Couto que trouxe um exercício de aterramento e reforço dos vetores das posições chave que nossos corpos encontraram. Posteriormente fizemos um desdobramento dessa proposta para adaptá-la às nossas necessidades que era o de dar o mesmo direcionamento dos vetores com a parceira em movimento. Esses procedimentos nos auxiliaram a perceber nosso corpo dentro do espaço todo e utilizá-lo com consciência.
} 
É importante reforçar que a decisão de deixar conexões vagas, eliminando elementos da forma foi decisiva para a qualidade cênica que conseguimos atingir dentro das nossas limitações. A busca pela essência incluiu, portanto, a utilização de um número reduzido de variáveis, para que as conexões possíveis sejam muitas, mas não em quantidade tão absurda que nossa mente não consiga abarcar. Dentre todas as decisões descritas acima, nenhuma configuraria um obstáculo ao entendimento caso não fosse compreendida pelo espectador.

$\mathrm{Na}$ apresentação seguinte nossa cena consistia numa mistura entre a primeira versão em dupla e a performance individual - momentos particularmente expressivos por estarem em plena experimentação e ordenação de associações.

1. Trocamos a cama por quatro cubos enfileirados e desencontrados formando dois pares. Os lenços (dois pretos e dois brancos) e os dois baralhos já estavam colocados na emenda dos pares de cubos.

2. Iniciamos com uma demonstração dos exercícios vocais e a movimentação a partir das imagens. A sonoridade e o vigor dos movimentos crescia, atingia um ponto máximo para depois relaxar, enquanto assumíamos uma frente. O texto é usado como num diálogo onde as intenções giram em torno da idéia de lamento (jovem) e conselho (velha)

3. A mais velha cobre-se com o véu preto e faz o mesmo com a parceira. Em seguida entrega-lhe um véu branco e um baralho, tendo os mesmos elementos reservados para si.

4. É feita a dinâmica de sobreposição de vozes e fôlegos enquanto o baralho é manuseado e o olhar da platéia é buscado.

5. Acontece a leitura da sorte para três pessoas da forma como foi descrito $^{67}$.

Houve certa unanimidade no julgamento de que este era o caminho a ser trilhado. A partir deste ponto, buscou-se por soluções cênicas e adensamentos de interpretação, mas a estrutura da cena permaneceu a mesma.

${ }^{67}$ Vide página 57. 
A essa altura o professor Armando havia determinado que o grupo seria dividido em dois sub-grupos que trabalhariam separadamente. Cada sub-grupo agregaria quatro cenas em processo que passariam a ser vistas semanalmente. Todos se obrigariam a apresentar seus progressos com maior freqüência e o professor se revezaria entre os dois, participando de ambos a cada quinze dias. Essa exigência foi extremamente benéfica porque evitava que perdêssemos demasiado tempo experimentando elementos que não se mostrariam eficientes na análise dos espectadores. A velocidade do amadurecimento da cena triplicou, o que foi ótimo.

Como foi de hábito, sentamos para uma conversa após a avaliação do grupo. Todo o material apresentado na cena anterior foi considerado pela platéia como orgânico e estabeleceu-se a comunicação com eficiência e verdade. Resistindo à vontade de investigar outros elementos que pudessem ser agregados, fechamos o projeto na estrutura criada na cena anterior. Tínhamos agora o seguinte:

- Uma seqüência razoavelmente encaminhada de relações estabelecidas pelo contato improvisação a partir das imagens e com a utilização do texto. Renata movia-se quase que exclusivamente pelo chão, em todo o espaço da cena ao redor dos cubos, com predomínio dos planos baixo e médio. Sandra mantinha-se em contato com os cubos quase que o tempo todo, explorando-os nos seus planos baixo, médio e alto.

- Uma quebra drástica para a posição de ambas sentadas sob os cubos com frentes invertidas. $\mathrm{O}$ texto era trabalhado como num mantra ou reza, fazendo-se uso do efeito dos fôlegos e sobreposição de vozes. 
- A leitura da sorte - momento mais bem resolvido pela sua própria característica, mas que também melhorou com uma atenção especial dada à ritualização dos gestos (sem torná-los não humanos) e numa ênfase moderada ao trabalho das costas.

Tínhamos três possíveis Atos que precisavam de lapidação. Decidimos organizá-los um por vez a partir de suas próprias associações. Todavia ainda faltavam definições. Como introduzir a relação das personagens e como explicitar as idéias que embasam essa relação eram preocupações que se relacionavam ao início da cena. Como encerrar a relação com o público, que se dava durante a leitura da sorte, era uma questão para ser resolvida no final.

Durante essa última fase dos ensaios atravessamos nossa terceira crise. Um elemento que nos era bastante agradável era a maneira neutra de apresentar o texto, próxima da leitura feita na primeira performance. Essa neutralidade nos parecia interessante enquanto introdução da situação propriamente dita, que percebíamos mais claramente elucidada como duas maneiras de se lidar com a perda. Mas em que momento a jovem (representada por Renata) entraria em cena. Queríamos que ambas estivessem presentes desde o começo para mantermos a idéia de dois lados da mesma situação, como na dualidade das figuras das cartas que já havíamos gostado anteriormente.

Mantendo-nos atentas à questão da dualidade, partimos de uma análise do roteiro da velha e tentamos estabelecer para esse conjunto de ações uma atitude oposta a partir dos conceitos de simetria e contraste.

\begin{tabular}{|c|c|}
\hline Velha & Jovem \\
\hline $\begin{array}{l}\text { Plano médio (sentada) com movimentos } \\
\text { lentos do tronco em torções para a esquerda e } \\
\text { direita. }\end{array}$ & $\begin{array}{c}\text { Planos alto e baixo com movimentos } \\
\text { amplas de torções para frente e para trás. }\end{array}$ \\
\hline Voz neutra & Vozes variáveis \\
\hline Olhar estabelecendo contato com a platéia & Olhar voltado para a cena ou para si. \\
\hline $\begin{array}{c}\text { Posição central da cena, girando em torno } \\
\text { do próprio eixo (rotação) }\end{array}$ & Deslocamento em círculo ao longo da \\
\hline Ação de manusear o baralho e os lenços \\
posicionando-os para a cena.
\end{tabular}


Restava definir, a partir dos elementos que estavam em cena ou que pudessem estar, algo que servisse de estímulo para ações que a jovem pudesse desempenhar. Que intenção teria ela dentro da cena? Para a velha concluímos que, enquanto detentora do conhecimento ela manuseava dois baralhos: o seu e aquele que estava destinado à sua jovem aprendiz. Existia, portanto, alguma conexão possível com o futuro. Decidimos fazer da jovem uma ponte para todas as relações de amor perdido que pudessem acontecer.

Como objeto elegemos uma escova de cabelos, devido a sua relação com o quarto que já era nossa referência, e pela mobilidade que esse objeto permite. Nas improvisações surgiu a necessidade de se pronunciar nomes masculinos e investigamos essa possibilidade durante algum tempo. O grupo avaliou esse princípio como interessante, mas estávamos insatisfeitas com o direcionamento para o amor homem/mulher porque tínhamos a sensação de uma nova redundância entre texto (que fala basicamente deste tipo de amor) e a ação da personagem. Queríamos incluir na dor da perda outros gêneros que podem deixar marcas tão profundas quanto o amor romântico. Foram então realizadas experiências buscando maneiras de se concretizar os diversos amores chegando-se aos seguintes: pais, por seus substitutos e amigos, além de algumas variações sobre o tema do amor romântico.

Chegamos a um resultado que consideramos satisfatório e, com a aprovação do grupo, fixamos nossas partituras. A fala neutra da velha, apesar de quase sempre ser satisfatória, por vezes permanecia vazia e sem vigor. Decidimos deixar esse problema de lado por algum tempo e passamos à parte que nos dava mais dor de cabeça: a relação.

Investigando mais atentamente as etapas desse segundo ato, verificamos que a jovem possuía um roteiro de intenções que facilitava o seu desenvolvimento, enquanto que a personagem da velha, que apresentava mais falhas, começava com força, passava para o deboche, para a pena chegando à dor. Eram sentimentos baseados nas muitas faces da perda sugeridas pelas estátuas. Mas essa variedade estava tornando difícil o entendimento da relação, pois a velha parecia sofrer de transtorno bipolar. Mais uma crise deflagrada pela indefinição que gerava grande desconforto e a sensação de "canastrice".

Para superar esta dificuldade uma sugestão dada foi a de procurar novas imagens que pudessem trazer maior clareza. Contudo, um dos objetivos desta pesquisa era verificar em que medida as idéias de Fayga sobre a ordenação de elementos podia contribuir para resolver 
problemas de interpretação. Voltamos, por essa razão, a verificar as possibilidades de ordenação, buscando uma reorganização interna e externa. Começamos por retirar a referência da "centauresse" do final da partitura, pois sua posição ajoelhada era o que estava dando ao final um ar de lamento e dor que não condizia com a idéia de aceitação proposta para a personagem. Obtivemos uma sensível melhora, um ganho que não se devia somente à mudança de "cor", mas ao fato de que, com menos movimentos a serem construídos, ampliou-se o tempo dedicado a cada um deles, aumentando a força da velha pelo contraste da sua imobilidade com o movimento febril daquele trecho que coincidia com a partitura da jovem.

Retomamos então os procedimentos de limpeza eliminando mais algumas referências e recuperamos o princípio de vetores para tentar alcançar um novo tônus de sustentação das posições, além de outro ritmo para as construções e novas ligações entre elas. Durante as improvisações reconhecemos em nossos movimentos algo semelhante a um exorcismo, pois as repetidas retro-flexões da jovem em oposição aos movimentos amplos e elevados da velha trouxeram essa leitura. A partir desse reconhecimento decidimos reordenar a cena para a condução de um exorcismo ao contrário, que não visava expulsar uma entidade politicamente incorreta, mas aceitá-la como parte de si, como procedem os médiuns da umbanda ao incorporarem entidades da esquerda. ${ }^{68}$

Essa idéia da esquerda vinha de encontro ao benefício que a raiva ou a dor pode às vezes trazer. Em algumas circunstâncias deve-se deixar que o mal venha e faça o seu trabalho em nossa vida. Fingir que ele não existe pode prolongar a dor, camuflá-la ou transferi-la para outras partes do corpo ou da nossa vida. Somente depois que se aceita um fato desagradável como consumado ou inevitável, como parte da existência e do equilíbrio das forças do universo, assim como toda a carga de ressentimento que sentimos enquanto seres humanos, é que podemos seguir adiante deixando a má experiência para trás.

\footnotetext{
${ }^{68}$ A Umbanda é uma religião politeísta que surgiu a partir do sincretismo entre o catolicismo e o candomblé africano. Uma de suas características é o agrupamento de suas divindades e espíritos guias em "linhas". Segundo essa crença, os espíritos que possuem os piores antecedentes e uma energia mais pesada fazem parte da linha da esquerda, composta essencialmente por Exus (masculinos) e Pombas-Gira (femininos). Quando essas entidades se manifestam, com certas variações próprias das regras de cada terreiro ou segundo o estágio evolutivo do espírito que se apresenta, é comum vermos os médiuns caírem abruptamente de joelhos, com corpos retorcidos e tomados por convulsões, gritos e gargalhadas. A função desses espíritos é proceder à limpeza do filho de santo, agindo sobre o mal feito ou carregado dentro do corpo. Essas entidades às vezes impõem aos médiuns ações bastante desconfortáveis, constrangedoras ou impressionantes e, na maior parte das vezes, parecem achar graça dos nossos receios e deslizes.O deboche e a malícia são atitudes bastante comuns, assim como uma certa cumplicidade de quem conhece de perto as vaidades humanas, suas causas e conseqüências. Informações cedidas pelo Pai de Santo Vladimir Sordi Nalio.
} 
Definida esta questão foi muito mais fácil reordenar o restante da cena. Após o ápice atingido pela metamorfose - que associamos à incorporação do exu - a jovem precisava se tranqüilizar. ${ }^{69}$

Com isso em mente voltamos nossa atenção para as últimas fases da cena. Após a relação tínhamos o momento do mantra, quando a jovem era definitivamente iniciada no conhecimento do amor e da morte e, devidamente instrumentada para esse saber, ela, assim como sua guia, passariam à orientação dos demais presentes. A emenda desse momento extremamente estático com o êxtase da incorporação estava excessivamente abrupto. Precisávamos desacelerar, desaquecer como diz Janô. Partindo da idéia do desacelerar do atleta, que caminha lentamente até que sua pulsação volte ao normal, chegamos à imagem da jovem caminhando lentamente ao redor da cena e, num discurso de formatura, apresentando o texto diretamente para o público como sua mestra fez no início da cena.

Para facilitar mais essa limpeza procuramos reordenar as idéias a partir dessa divisão em cinco Atos que acabou por se estabelecer. Retomando a questão da iniciação à vivência da dor pela perda, trouxemos de volta nossas associações entre as práticas ritualísticas que tínhamos acesso direto (o catolicismo e a umbanda) e procuramos confirmar as conexões possíveis com nossa estrutura de cena. Através dessa abordagem estávamos recuperando questionamentos acerca do mal que não pode ser ignorado (a morte existe, o amor acaba, temos um lado obscuro em nós que pode ser desagradável, mas nos empurra para a ação, a superação e a sobrevivência) e fortalecendo em nós as associações e as formas obtidas. A cena ficou finalmente definida nos seguintes moldes: (ilustração 6).

$1^{\circ}$ - apresentação dos antecedentes da situação dramática "o amor acaba”.

- O que aconteceu antes.

- Identificação com o momento de aquecimento

- Os muitos amores que acabam.

\footnotetext{
${ }^{69}$ Como procedem os médiuns - recebem a entidade, que age neles e através deles, e, com a sua saída, precisam de um certo tempo para se recomporem. São amparados pelos mais experientes que os acalmam com abraços e beijos. Somente depois de alguns instantes é que novamente se aproximam do altar para a benção do pai de santo que funciona quase como uma liberação para a volta à vida comum. Muito semelhante ao procedimento de "desaquecer".
} 
- $\mathrm{O}$ ato de anunciar que a hora da iniciação está próxima.

\begin{tabular}{|c|c|c|}
\hline ações & Velha & Jovem \\
\hline intenção & $\begin{array}{l}\text { Eu sei o seu destino. } \\
\text { A vida é assim. }\end{array}$ & Eu amo. \\
\hline movimentos & $\begin{array}{l}\text { Sentada nos cubos, usa de } \\
\text { torções para acompanhar a movimentação } \\
\text { da jovem. } \\
\text { Prepara objetos que serão } \\
\text { utilizados na cena. O baralho, os lenços. }\end{array}$ & $\begin{array}{l}\text { Movimenta-se por estações de } \\
\text { memórias. O primeiro beijo, a babá, a } \\
\text { paixão física, o baile, o pai. Uso de uma } \\
\text { escova de cabelos (quarto) para } \\
\text { materializar as relações que traz para a } \\
\text { cena. Gestos de esgrima }\end{array}$ \\
\hline VOZ & $\begin{array}{l}\text { Neutra. Comunicando uma } \\
\text { verdade. Dirigindo-se diretamente para os } \\
\text { espectadores, mas atenta à movimentação } \\
\text { da parceira. }\end{array}$ & $\begin{array}{l}\text { Com as intenções do repertório } \\
\text { da atriz }\end{array}$ \\
\hline Imagens & $\begin{array}{l}\text { Puberdade } \\
\text { Velha torcida } \\
\text { Café noturno }\end{array}$ & $\begin{array}{c}\text { Posições da escova (alturas, } \\
\text { contato com o corpo) inspirando a relação }\end{array}$ \\
\hline texto & $\begin{array}{l}1^{\mathrm{a}} \text { metade de "O amor acaba" de } \\
\text { "O amor acaba" até “em } \\
\text { apartamentos refrigerados, atapetados,..." }\end{array}$ & $\begin{array}{l}\text { Frases curtas com relação } \\
\text { específica à cena - material do repertório } \\
\text { pessoal da atriz. } \\
\text { "Beijo abraço ou aperto de } \\
\text { mão?" } \\
\text { "Vem que eu estou te pedindo." } \\
\text { "Nena, ta doendo!!" } \\
\text { "João, aqui não!" } \\
\text { "Paiê, eu te amo um tantão } \\
\text { assim" "Nomes de homens" } \\
\text { posteriormente eliminados. }\end{array}$ \\
\hline
\end{tabular}

$2^{\circ}$ - $\mathrm{O}$ rito de iniciação.

- $\mathrm{O}$ amor acabou - a jovem entra em desespero.

- A procura pela ajuda do conhecimento.

- $O$ rito se inicia. A sacerdotisa conduz a inicianda até a metamorfose. 
- Vivenciar a dor para renascer dela.

- A consagração da missa.

- A benzedeira que purga a doença.

- O médium experiente que auxilia o iniciante ainda inseguro.

\begin{tabular}{|c|c|c|}
\hline ações & Velha & Jovem \\
\hline intenção & $\begin{array}{l}\text { Eu invoco o mau que existe } \\
\text { em você para que você sobreviva. } \\
\text { É assim que tem que ser }\end{array}$ & Eu não aceito \\
\hline movimentos & $\begin{array}{l}\text { Benzer } \\
\text { Consagrar } \\
\text { Invocar } \\
\text { Ápice } \\
\text { Saudar } \\
\text { Uso constante do baralho } \\
\text { elemento representante do } \\
\text { conhecimento. }\end{array}$ & $\begin{array}{l}\text { Dor } \\
\text { Resistência } \\
\text { Rompimento } \\
\text { Relaxamento }\end{array}$ \\
\hline VOZ & $\begin{array}{l}\text { Trazida de baixo } \\
\text { Num crescente até o êxtase }\end{array}$ & $\begin{array}{l}\text { Sons inarticulados } \\
\text { Gargalhada }\end{array}$ \\
\hline Imagens & $\begin{array}{l}\text { Chupando os dedos } \\
\text { Lês demoiselles } \\
\text { Lutador } \\
\text { Vitória } \\
\text { Pomba-gira }\end{array}$ & $\begin{array}{l}\text { O homem que cai } \\
\text { Leão chorando } \\
\text { Exu } \\
\text { Torso }\end{array}$ \\
\hline texto & Repetição do texto da $1^{\mathrm{a}}$ parte & Sem texto articulado \\
\hline
\end{tabular}

$3^{\mathrm{a}} \mathrm{O}$ desaquecimento.

- A aceitação

- A recuperação depois da experiência

- A limpeza da bagunça - o recolhimento das cartas

- O consolo.

- O recebimento dos símbolos do conhecimento. 


\begin{tabular}{|c|c|c|}
\hline ações & Velha & Jovem \\
\hline intenção & É assim. Seja bem vinda & $\begin{array}{lllll} & \text { É assim. Essa é a minha } \\
\text { história } & & & & \\
\end{array}$ \\
\hline movimentos & $\begin{array}{l}\text { Limpar-se } \\
\text { Limpar o espaço. } \\
\text { Cobrir-se - o sagrado } \\
\text { Receber o iniciado e consolar. } \\
\text { Abençoar }\end{array}$ & $\begin{array}{l}\text { Divagar } \\
\text { Lamentar } \\
\text { Receber a benção } \\
\text { Ser coberta - iniciada }\end{array}$ \\
\hline VOZ & Reza - murmúrio & $\begin{array}{l}\text { Trazida de baixo } \\
\text { Aos poucos se harmoniza com } \\
\text { o murmúrio da mestra }\end{array}$ \\
\hline Imagens & $\begin{array}{l}\text { Pietá } \\
\text { Puberdade alterada }\end{array}$ & $\begin{array}{l}\text { Pietá } \\
\text { Puberdade alterada }\end{array}$ \\
\hline texto & $\begin{array}{l}2^{\mathrm{a}} \text { parte do texto em mantra } \\
\text { crescente (sentada) }\end{array}$ & $\begin{array}{l}2^{\mathrm{a}} \text { parte do texto dirigida ao } \\
\text { espectador (caminhando) } \\
2^{\mathrm{a}} \text { parte do texto em mantra } \\
\text { crescente (sentada) }\end{array}$ \\
\hline
\end{tabular}

$4^{\mathrm{a}}$ Leitura da sorte

- Compartilhando o conhecimento com aqueles que também irão vivenciá-lo repetidas vezes.

- Finalização do ritual - Benção final - Rito de despedida para prolongamento do efeito do ritual para a vida dos participantes (Canto final como nos folhetos de missa)

\begin{tabular}{|l|l|}
\hline ações & Velha e Jovem \\
\hline intenção & Eu te revelo o seu destino. \\
& Ide em paz e o Senhor vos acompanhe \\
\hline movimentos & Cobrir o ouvinte \\
& Beijar as mãos \\
& Escolher uma carta \\
& Montar a leitura \\
& Beijar a testa \\
& Retirar o lenço \\
& Descobrir-se \\
\hline
\end{tabular}




\begin{tabular}{|c|l|}
\hline & Acender a vela \\
& Passar a luz \\
& Cântico final \\
\hline voz & Murmúrio das frases finais do texto \\
& Trazida de baixo nas cartas pretas. \\
& Nasaladas nas cartas vermelhas \\
\hline Imagens & Coroinnha trazendo as hóstias. \\
& Procissão \\
\hline texto & "Em todos os lugares o amor acaba" até o fim \\
& Reorganização das frases finais para reforçar a idéia de recomeço na \\
& despedida do ouvinte. \\
& Profecias - partes do texto e revelações diversas \\
& Canção “O amor acaba" 70 \\
\hline
\end{tabular}

A cena ficou assim formatada a poucas semanas da data prevista para a abertura de processo, onde teríamos a oportunidade de mostrá-la para um público não familiarizado com o percurso. Continuamos com ensaios e apresentações semanais para o grupo onde os colegas nos indicavam potencialidades a serem aprofundadas e pontos frágeis na nossa produção. As indicações mais constantes giraram em torno do jogo de intensidades e variações de ritmo, tanto na fala como no corpo, e os diferentes resultados que essa variáveis traziam para a performance. Dedicamo-nos nesta reta final à experimentação das diferenças que pequenas sutilezas podiam acarretar. Essas mínimas alterações eram capazes de transformar um momento que parecia se arrastar por minutos intermináveis para a platéia - que chegou a sugerir o seu corte - numa seqüência absolutamente equilibrada e bem resolvida.

Faltavam ainda alguns detalhes importantes, sem dúvida, mas que não estávamos certas de ser ainda o momento adequado para ocuparmo-nos deles. De qualquer modo, a “avaliação final” se aproximava e o grupo planejava estabelecer uma seqüência de cenas que se ajudassem mutuamente pela identificação de temas ou linguagens. Escolhemos conjuntamente com os colegas do dia algumas opções para iluminação, estabelecemos uma ordenação que pareceu razoavelmente adequada e concretizamos um figurino básico mantendo idéias como a da viúva e da noiva, o conhecimento secreto e a inocência. Recuperamos uma imagem do uso de velas durante a cena, que já havia sido considerada enquanto ambiente, devido à associação com ambientes sagrados (no filme São Bernardo

\footnotetext{
${ }^{70}$ De autoria do nosso colega José Raimundo.(Anexo 6 p 123. )
} 
acontece uma cena interessante na capela da fazenda). Entretanto, nenhuma dessas opções foi considerada final, também elas deveriam passar pelas bases do nosso procedimento que exigia ainda um tempo dedicado a experimentações e ordenações diversas.

Estava finalmente definida nossa versão de Gertrudes e Ofélia. Desconsiderando-se os nervosismos de "estréia" o público avaliou a cena como interessante no painel do espectador $^{71}$. Enquanto atrizes e diretoras, temos a seguinte visão dos resultados alcançados:

- A variedade de intensidades e ritmos tornou a obra dinâmica o suficiente para manter o público atento. Para isso contribuíram a brevidade da cena (28 minutos) e momentos com qualidades razoavelmente contrastantes e intensas devido à proximidade ou por serem trazidas informações absolutamente novas de tempos em tempos.

- A qualidade do contato improvisação acabou permeando todos os Atos e dava-nos segurança suficiente para acompanharmos a dinâmica que se impunha naquele momento sem prejuízos de relação, ritmo ou movimentos internos.

- Alguns elementos são garantia de envolvimento, como é o caso da leitura da sorte que instigava alguns e literalmente apavorava a outros.

- A proximidade criou, segundo relatos, a impressão de estar dentro do espaço cênico, sendo observado como se em cena. Ainda que um tanto inibidos em princípio, os espectadores não se sentiram invadidos ou forçados como acontece em algumas montagens, o que permitiu a conivência com as personagens numa participação aceita.

\footnotetext{
${ }^{71}$ Painel preparado por nós para que os espectadores pudessem deixar algumas impressões sobre as cenas apresentadas registradas de imediato. Foram feitas duas apresentações dias 1 e 2 de dezembro Nossa cena dividiu o dia com mais três outros trabalhos de colegas do grupo de pesquisa. No final de semana seguinte foi a vez das cenas restantes.
} 
Para avaliar os procedimentos desenvolvidos e relatados nestas páginas é preciso que se faça algumas considerações.

Em toda nossa abordagem partimos do princípio que "artistas" e "não artistas" possuem os mesmos recursos e habilidades necessárias para que um processo de criação se 
amadureça e dê frutos. Já que ambos estão em igualdade de condições, o que determinaria as diferenças de resultados que os separam em categorias diferentes?

Pensamos que novamente estamos tratando de escolhas. Aquele que recebe da sociedade o nome de artista escolheu a arte como veículo de reflexão, análise, comunicação e expressão. Uma grande porção do seu tempo será dedicada à descoberta e aplicação de conhecimento artístico - o que obviamente contribuirá para um domínio técnico que outros interessados no uso da arte não alcançarão facilmente. Outras pessoas optaram por dar rumos diferentes aos seus potenciais de criação, e os usam sempre que precisam resolver dificuldades ou dúvidas. Para aqueles que querem experimentar fazer uso da arte, como primeiro contato ou como parte da sua formação, concluímos que existem três ações que julgamos facilitarem a jornada.

É importante que o candidato adquira o hábito saudável de ser curioso e que tenha vontade de descobrir potencialidades em si mesmo e no ambiente que o rodeia. Investigar as qualidades e comportamentos dos materiais que pretende usar deve ser uma prioridade, sejam eles tintas, argila, máquina fotográfica, o corpo, a voz ou as propriedades da língua. Observar com atenção e conhecer os limites é a base sólida que ele precisará para dar saltos e fazer piruetas de toda espécie. É a resistência do chão, que não nos permite ultrapassá-lo, que nos impulsiona para o alto. E quem seria capaz de afirmar que a limitação imposta pelo solo atrapalha as infinitas possibilidades de criação do ginasta, do bailarino ou daquele que ama a dança no seu corpo comum? Da interação entre as características do material e a ação criativa do homem são estabelecidas as bases da linguagem artística, que deve ser investigada e dominada para que se consiga submeter a matéria, respeitando-a enquanto interlocutora.

A segunda questão importante é conhecer os mecanismos por onde opera a linguagem escolhida para que se possa procurar por ordenações compositivas satisfatórias, estando consciente dos conceitos que delimitam a sua expressão. Nesse âmbito são válidos estudos acadêmicos, experiências práticas compartilhadas ou análise atenta de exemplos de outros artistas. Todos esses caminhos permitem o treinamento da sensibilidade e do pensamento necessários para que se possa seguir em frente e encontrar suas próprias respostas. Ao compor é preciso manter viva a chama que impulsiona a busca pela coerência e estar sempre disposto a recomeçar se ainda houverem descobertas a fazer. 
A última questão a observar é estar atento ao seu repertório e alimentá-lo com vivências conscientes. Exercitar esses poderosos instrumentos que são a percepção e as associações deve se tornar um hábito com clareza de objetivos, para não manter-se apenas na busca de materializar suas referências, mas entendendo-as como elementos a serem articulados novamente e em novo contexto.

Acreditamos que todos podem criar através da arte porque executar as ações descritas acima de forma sistemática é uma habilidade que pode ser adquirida porque é compreensível, e podemos dominar aquilo que entendemos. A disciplina, é sem dúvida, indispensável, principalmente em áreas tão subjetivas quanto a criação artística. Mas o treino e a repetição de experiências trarão consigo a necessária familiarização indispensável para se chegar a ter confiança e conforto. Essencial é agir. Os resultados virão.

Da nossa parte, a maior comprovação foram dificuldades de interpretação reais, apontadas por observadores ou sentidas pelas intérpretes, que puderam encontrar soluções mais satisfatórias em retomadas dos estímulos, novamente examinados nas suas qualidades e reordenados em busca da forma equilibrada e consistente. É importante destacar que não estamos aqui falando apenas de distribuição de elementos numa seqüência. $\mathrm{O}$ movimento interno do ator é mais um componente desta obra final que é a cena e deve, como tal, ser também composto nas suas variáveis, desdobramentos e relações com os demais integrantes dessa obra com consciência, rigor e carinho.

\section{BIBLIOGRAFIA}

APPIA, Adolphe - A obra de arte viva - Ed. Arcádia, Lisboa, 1919

ARNHEIM, Rudolf - Arte e percepção visual. Uma psicologia da visão criadora - Ed.

Pioneira, São Paulo, 1986.

ARTAUD, Antonin - O teatro e seu duplo - Ed. Martins Fontes, São Paulo, 1999.

BALL, David - Para trás e para frente - um guia de leitura para peças teatrais - Ed. 
Perspectiva, São Paulo, 1999.

BARBOSA, Ana Mãe - A imagem no ensino da arte - Ed. Perspectiva, São Paulo, 2001 BERTHOLD, Margot - História mundial do teatro - Ed. Perspectiva, São Paulo, 2001 BOSI, Alfredo - Reflexões sobre a arte - Ed. Ática, São Paulo, 1989

BRAZ, Luzia Carion - A iniciação ao treinamento do ator através da técnica corporal

desenvolvida por Klauss Vianna - dissertação de mestrado, ECA-USP, 2004

BRITO, Beatriz de Araújo - $\underline{O}$ inconsciente no processo criativo do ator - por uma cena dos

sentidos (a experiência da criação coletiva) - dissertação de mestrado, ECA-USP. 2001

BROOK, Peter - Fios do tempo - Ed. Bertrand Brasil, Rio de Janeiro, 2000

CHACRA, Sandra - Natureza e sentido da improvisação teatral - Perspectiva, São Paulo,

1983

COLASANTI, Marina - Contos de amor rasgado - Ed. Rocco, Rio de Janeiro, 1986

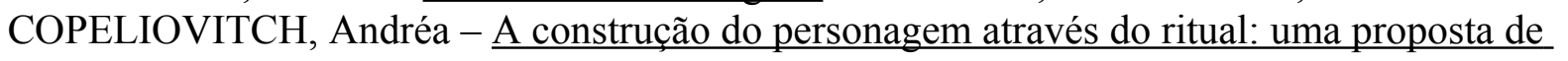

aprendizado para o ator - dissertação de mestrado, ECA-USP, 1997

FERRACINI, Renato - A arte de não interpretar como poesia corpórea do ator - Ed.

Unicamp, Campinas, 2003

FUSER, Rachel Araújo de Baptista - Para uma pedagogia do ator - dissertação de mestrado,

ECA-USP, 1993

GALVÃO, Walnice Nogueira - Clarice Lispector - coleção os melhores contos, Ed. Global,

São Paulo, 1995

GOMBRICH, E. H. - A história da arte - Ed. Guanabara Koogan, Rio de Janeiro, 1993

GROTOWSKI, Jerzy - Teatro laboratório - Ed. Tusquets, Barcelona,1980

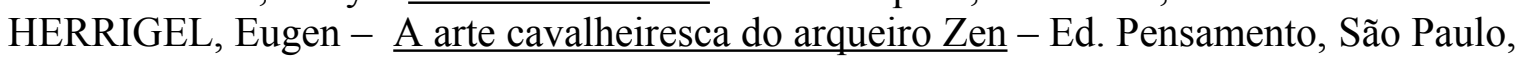

2003

HUIZINGA, Johan - Homo Ludens - Ed. Perspectiva, São Paulo, 1999

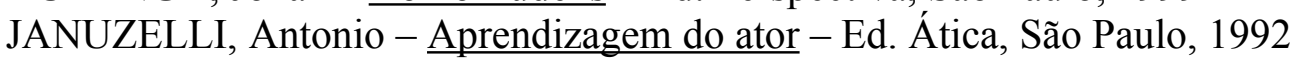

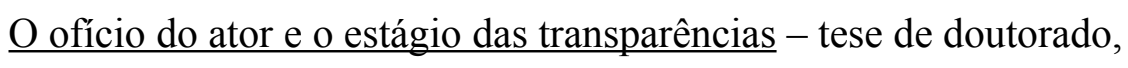

ECA-USP, 1992

KOTT, Jan - Shakespeare nosso contemporâneo - Ed. Cosac \& Naif, São Paulo, 2003

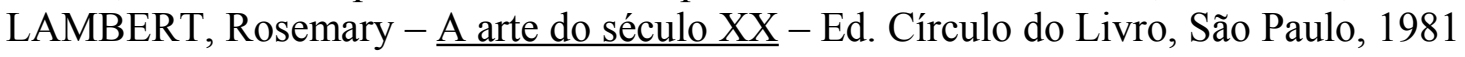

LOBO, Lenora e NAVAS, Cássia - Teatro do movimento. Um método para o intérprete

criador - Secretaria de Estado da Cultura do D.F., Brasília, 2003

MARLOW, Tim - $\underline{\text { Rodin }}$ - Ed. Ao Livro Técnico, Rio de Janeiro, 1995

ORNELLAS, Raquel - Caldeirão de bruxas - Edusp, São Paulo, 2006

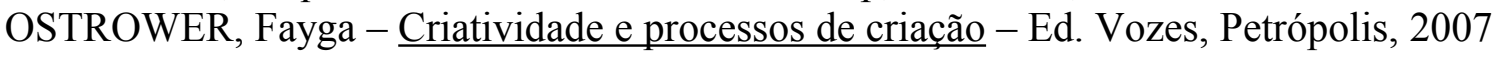

Acasos e criação artística - Ed. Elsevier, Rio de Janeiro, 1999.

Universos da arte - Ed. Campus, Rio de Janeiro, 1983

PAVI, Patrice - Dicionário de teatro - Ed. Perspectiva, São Paulo, 1999

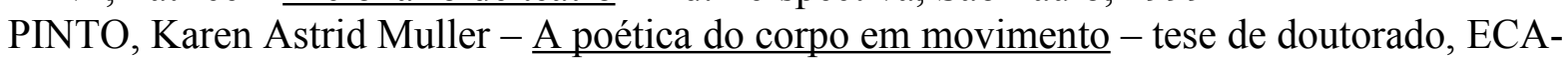

USP, 2002

PINTO, Luciana Saul - Rituais do candomblé: uma inspiração para o trabalho criativo do

ator - dissertação de mestrado, ECA-USP, 2006

PORTELA, Eduardo (org.) - Lygia Fagundes Telles - coleção os melhores contos, Ed. 
Global, São Paulo, 1997

ROSENFELD, Anatol - O teatro épico - Ed. Perspectiva, São Paulo, 2000

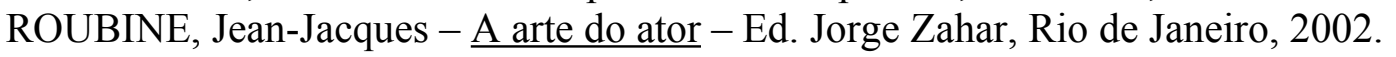

A linguagem da encenação teatral - Ed. Jorge Zahar, Rio de

Janeiro, 1998;

SILVA, Armando Sérgio da - Oficina da Essência - Resumo reprográfico da tese de Livre

Docência, Mogi das Cruzes, 2003

SOURIAU, Etienne - A correspondência das artes. Elementos da estética comparada - Ed.

Cultrix, São Paulo,1983

SPOLIN, Viola - Improvisação para o teatro - Ed. Perspectiva, São Paulo, 1979

STANISLAVSKI, Constantin - A preparação do ator - Ed. Civilização Brasileira, Rio de

Janeiro, 1999. A criação de um papel - Ed. Civilização Brasileira, Rio de

Janeiro, 2003

STEINBECK, John - A leste do Éden - Ed. Círculo do livro, São Paulo, sd.

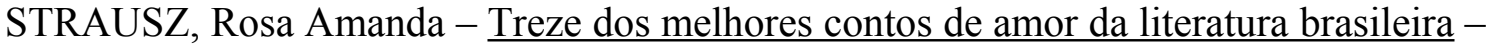

Ediouro, Rio de Janeiro, 2002.

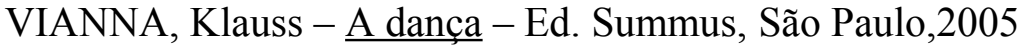

\section{SITES VISITADOS}

http//www.caixadoteatro.com.br - Textos de teatro

$\mathrm{http} / / \mathrm{www}$.encena.com.br - teatro

http//www.faygaostrower.org.br - página do Instituto Fayga Ostrower

$\mathrm{http} / / \mathrm{www}$.pageguilder.com.br/proscenio - Textos de teatro

\section{CD-ROM}

\section{ENCICLOPÉDIA DA PINTURA MODERNISTA BRASILEIRA}

Organizada por Mariela Mielzynska Kantor

Próxima Mídia Editora, Rio de Janeiro

ENCICLOPÉDIA MULTIMIDIA DA ARTE UNIVERSAL

Caras e Alphabetum Ed. Multimidia

OS GRANDES PINTORES MULTIMIDIA

F\&G Editores, Madrid 
FILMOGRAFIA

$\underline{\text { SÃO BERNARDO }}$ - 1972 - direção de Leon Hirszman - com Othon Bastos e Isabel Ribeiro - fotografia de Lauro Scorel

\section{ANEXOS}




\section{Anexo 1}

\section{Hamlet}

\section{Ato III cena IV}

Cena IV

Aposento da Rainha.

(Entram a Rainha e Polônio.)

POLÔNIO: Ele aí vem; repreendei-o asperamente; mostrai que se excedeu nas

brincadeiras, e como se interpôs Vossa Grandeza entre ele e a grande cólera. Mais nada; somente vos reitero: sede ríspida.

HAMLET: (dentro): Mãe! Mãe!

A RAINHA: Podeis ficar tranqüilo; retirai-vos; está ele chegando.

(Polônio se esconde atrás do reposteiro.)

(Entra Hamlet.)

HAMLET: Então, mãe, que há de novo?

A RAINHA: Grande ofensa a teu pai fizeste, Hamlet.

HAMLET: Grande ofensa a meu pai fizeste, mãe.

A RAINHA: Devagar; respondeis com língua ociosa.

HAMLET: Vamos, que me falais com língua ociosa.

A RAINHA: Que é isso, Hamlet?

HAMLET: Que há de novo agora?

A RAINHA Esquecestes quem sou?

HAMLET: Não, pela Cruz!

Não me esqueci. Sei bem que sois a rainha, casada com o irmão de vosso esposo e - prouvera o contrário - minha mãe.

A RAINHA Vou chamar quem convosco falar possa.

HAMLET: Vamos, sentai-vos; não saireis enquanto não vos apresentar eu um espelho que o recôndito da alma vos reflita.

A RAINHA Que pretendes fazer? Não vais matar-me? Socorro! Socorro!

POLÔNIO (atrás): Que é que há? Socorro! Socorro!

HAMLET: (desembainhando a espada): Que é isso? Um rato? (Dando uma estocada no reposteiro.) Aposto que o matei. 
POLÔNIO: (atrás): Estou morto!

A RAINHA: Santo Deus, que fizeste!

HAMLET: Ignoro-o. Não era o rei?

A RAINHA: Que ação precipitada e sanguinária!

HAMLET: Ação precipitada e sanguinária?

Tão ruim, boa mãe, quanto matar

um rei e desposar o irmão do morto.

A RAINHA: Matar um rei?

HAMLET: Um rei; foi o que eu disse.

(Levanta o reposteiro e descobre o corpo de Polônio.)

Adeus, bobo apressado e intrometido.

Julguei que era o teu chefe; é o teu destino.

Vês que o ser serviçal traz seus perigos. Não torçais tanto as mãos; sentai-vos;

quero

lutar com vosso coração; no caso

de ser ele amolgável, se o maldito

costume o não deixou duro como o aço,

A RAINHA: Que fiz eu para usares de linguagem tão grosseira?

HAMLET: Uma ação que mancha a graça e o rubor da modéstia, que a virtude transforma em falsidade, muda as rosas da fronte prazenteira do amor puro em chaga repugnante, e os juramentos dos cõnjuges em pragas de viciados. Uma ação que do corpo dos contratos tira a própria alma e muda em palavrório a doce religião; a própria face do céu cora de pejo; sim, o mundo compacto, nas feições mostra a tristeza do juízo final, diante desse ato.

A RAINHA: Ai! que ação tão monstruosa, que troveja estrondeando, com o simples enunciado?

HAMLET: Mirai este retrato e mais este outro, que dois irmãos fielmente representam; vede a graça que encima esta cabeça, cachos de Apolo, a fronte alta de Júpiter, o olhar de Marte, ao mando e à ameaça afeito, o porte de Mercúrio, o mensageiro, quando pousa nos cumes altanados; uma forma, em resumo, perfeitíssima, em que os deuses seus selos imprimiram para que o mundo visse o que era um homem: esse, foi vosso esposo. Agora o resto: eis vosso esposo, espiga definhada que o irmão sadio empesta. Tendes olhos? Deixastes a pastagem deste belo monte por um pau? Ah! tendes olhos? Não chameis a isso amor, que em vossa idade o sangue se arrefece, fica humilde e obedece à razão. E que razão passa deste para este? Sois sensível, pois vos moveis; mas tendes os sentidos paralisados. A loucura acerta; nunca os sentidos ficam subjugados pela paixão, a ponto de falharem totalmente na escolha. Que demônio vos logrou de uma vez na cabra-cega? O olho sem tato, o tato sem visão, o ouvido só por si, o olfato apenas, a menor parte, em suma, de um sentido verdadeiro, jamais se estontearia desse feitio. Pudor, por que não coras? Se nos ossos de uma matrona, inferno, te rebelas, que a continência fique, para os moços ardentes, como a cera, que amolece no próprio fogo; nem de mancha fales, quando no ataque se atirar o instinto, uma vez que é tão quente a própria geada e a razão é alcoveta da vontade.

A RAINHA: Não fales mais, Hamlet; a olhar me forças no mais íntimo da alma, onde acho manchas profundas e tão negras, que não perdem jamais a cor.

HAMLET: Viver num leito infecto que tresanda a fartum, onde fervilha a podridão, juntando-se em carícias num chiqueiro asqueroso!

A RAINHA: Oh! Não prossigas!

Apunhalam-me o ouvido essas palavras. Basta, querido Hamlet! 
HAMLET: Um assassino, um vil escravo, que não é um vigésimo do outro marido, um rei-bufão, um simples gatuno do governo desta terra, que a coroa empalmou da prateleira e a pôs no bolso.

A RAINHA: Basta!

HAMLET: Um rei-palhaço, em trajes de mendigo...

(Entra o Fantasma.)

Estendei sobre mim, legiões celestes as asas protetoras! Que deseja vossa imagem graciosa A RAINHA: Ai de mim! Está louco.

HAMLET: Não viestes censurar o filho tardo, que deixa a ira assentar, e tão remisso se mostra no cumprir vossos preceitos? Oh, dizei!

O FANTASMA: Não te esqueças: minha vinda só visa a estimular-te o intento rombo. Mas vê que em tua mãe se assenta o espanto.

Corre a interpor-te entre ela e a sua alma em luta, que nas pessoas fracas é terrível o estrago da ilusão. Fala-Ihe, Hamlet.

HAMLET: Senhora, que sentis?

A RAINHA: Que se passa contigo, que os olhos assim pousas no vazio e com o ar incorpóreo deblateras? Como se te ilumina a alma nos olhos! E tais como soldados, quando o alarma vem tirá-los do sono, teus cabelos, parecendo com vida, se desmancham, se curiçam na tua fronte. Ó meu bom filho!

Lança a fria paciência sobre as chamas e o fogo do teu mal. Mas, para onde olhas? HAMLET: Para ele, sim; quão pálido nos fixa! Seu destino e sua forma, se influissem nas pedras, racionais as tornariam. Tirai de mim os olhos, para que esse gesto

piedoso não transmude minhas ásperas intenções, pois o que tenho para fazer exige cores vivas. Necessito de sangue em vez de lágrimas. A RAINHA: Para quem falas isso?

HAMLET: Ninguém vedes?

A RAINHA: Ninguém; no entanto vejo o que nos cerca.

HAMLET: E nada ouviste?

A RAINHA: Nada; a nós somente.

HAMLET: Vede ali! Vede! Já se afasta... Meu pai, tal como em vida se vestia. Acaba - vede-o! - de transpor a porta.

(Sai o Fantasma.)

A RAINHA: Isso é fruto, somente, de teu cérebro. É sempre muito fértil o delírio no inventar essas coisas.

HAMLET: Delírio!

Meu pulso, como o vosso, é compassado; toca música sã. Não foi loucura quanto falei; ponde-me à prova: posso dizer tudo de novo. Um desvairado divagaria. Mãe, por vossa graça, não lisonjeeis vossa alma, acreditando que ouvis um louco e não vosso delito. A úlcera externa, assim, se fecharia, enquanto a corrupção minara tudo por dentro, sem ser vista. Ao céu volvei-vos; mostrai-vos do passado arrependida; evitai o futuro, sem que o joio adubeis e lhe deis, assim, mais viço. Perdoai-me esta virtude, que nesta época bem cevada e de fôlego cortado necessita a virtude rebaixar-se ao próprio vício e apresentar-lhe escusas por tudo o que de bem possa fazer-lhe.

RAINHA Hamlet, o coração em dois me partes.

HAMLET: Jogai fora a metade que não presta, para com a outra parte serdes pura.

Boa noite.

Mas evitai a cama do meu tio; fazei-vos de virtuosa, se o não fordes. O hábito, esse demônio que devora todos os sentimentos, nisso é um anjo, pois para o uso de ações boas e belas empresta vestimenta ou capa externa que lhes vão bem. 
Abstende-vos por hoje, que isso há de conferir facilidade à próxima abstinência; a outra, mais fácil vos há de parecer, que o uso consegue quase modificar a natureza, dominar o demônio e até expeli-lo com poder prodigioso. Uma vez mais, boa noite. Hei de pedir a vossa bênção, quando dela também necessitardes. Enquanto a este homem, faz-me pena; qui-lo desta arte o céu: punir a mim por ele, e a ele por mim. Fui servo, a um tempo, e açoite. Vou cuidar dele; fico responsável por esta morte. $\mathrm{E}$ ainda uma vez: boa noite. Preciso ser cruel para ser bom; o ruim começa; o pior já se acha feito. Uma palavra mais, senhora.

A RAINHA: Que é preciso que eu faça?

HAMLET: Nada do que vos disse neste instante. Que outra vez para o leito o rei balofo, vos conduza e no rosto vos belisque vos chame de ratinha, e que dois beijos infectos e carícias com as mãos grossas em vossas costas pronto vos induzam a revelar-lhe que estou bom do juízo, mas que finjo loucura. Dizei-lhe isso. Que rainha sensata, bela e honesta esconderia coisas tão preciosas de um sapo, de um morcego? É concebível? Apesar do bom senso, abri a gaiola no telhado e deixai fugir o pássaro; depois, como o macaco conhecido, entrai nela e fazei logo a experiência para em baixo partirdes o pescoço.

A RAINHA: Fica tranqüilo; se o falar consiste em respirar, e o fôlego for vida, não terei vida alguma que respire quanto me revelaste.

HAMLET: Parto para a Inglaterra; já o sabíeis?

A RAINHA: Ai! que o esquecera... Assim ficou assentado.

HAMLET: Selaram cartas; meus dois companheiros de escola, em quem me fio como em dentes de víbora, se encontram com a incumbência de aplanar-me o caminho e conduzir-me direto ao cativeiro. Pois trabalhem! Há de ser engraçado ver a bomba fazer saltar o autor. Por mais dificil que seja, hei de cavar mais fundo ainda, para jogá-los no alto. Como é belo ver a astúcia vencer a própria astúcia! Este homem me ajudou a fazer as malas; vou pôr no quarto anexo esta barriga. Boa noite, mãe. Realmente, o conselheiro que era tão falador, está sisudo: quietinho, bem discreto, grave e mudo. Vamos, senhor, dar fim a este negócio. Boa noite, mãe. (Saem por lados diferentes, arrastando Hamlet o corpo de Polônio.) 


\section{Anexo 2}

\section{"Pérolas" Lygia Fagundes Telles}

Demoradamente ele a examinava pelo espelho. "Está mais magra, pensou. Mas está mais bonita. "Quando a visse, Roberto também pensaria o mesmo: "Está mais bonita assim."

Que iria acontecer? Tomás desviou o olhar para o chão. Pressentia a cena e com que nitidez: com naturalidade Roberto a levaria para a varanda e ambos se debruçariam no gradil. De dentro da casa iluminada, os sons do piano. E ali fora, no terraço deserto, os dois muito juntos se deixariam ficar olhando a noite. Conversariam? Claro que sim, mas só nos primeiros momentos. Logo atingiriam aquele estado em que as palavras são demais. Quietos e tensos, mas calados na sombra. Por quanto tempo? Impossível dizer, mas o certo é que ficariam sozinhos uma parte da festa, apoiados no gradil dentro da noite escura. Só os dois, lado a lado, em silêncio. $\mathrm{O}$ braço dele roçando no braço dela. $\mathrm{O}$ piano.

- Tomás, você está se sentindo bem? Que é, Tomás?!

Ele estremeceu. Agora era Lavínia que o examinava pelo espelho.

- Eu? .. Não, não se preocupe - disse ele, passando as pontas dos dedos pelo rosto. - Preciso fazer a barba ...

- Tomás, você não me respondeu - insistiu ela. - Você está bem?

- Claro que estou bem.

A ociosidade, a miserável ociosidade daqueles interrogatórios. "Você está bem?" O sorriso postiço. "Estou bem." A insistência era necessária. "Bem mesmo?" Oh Deus. "Bem mesmo."

A pergunta exasperante: "Você quer alguma coisa?" A resposta invariável: "Não quero nada."

"Não quero nada, isto é, quero viver. Apenas viver, minha querida, viver. .. " Com um movimento brando, ele ajeitou a cabeça no espaldar da poltrona. Parecia simples, não? Apenas viver. Esfregou a face na almofada de crochê. Relaxou os músculos. Uma ligeira vertigem turvou-lhe a visão. Fechou os olhos quando as tábuas do teto se comprimiram num balanço de onda. Esboçou um gesto impreciso em direção à mulher:

- Sinto-me tão bem ...

- Pensei que você estivesse com alguma dor.

- Dor? Não. Eu estava mas era pensando.

LavÍnia penteava os cabelos. Inclinara-se mais sobre a mesinha, de modo a poder ver melhor o marido que continuava estirado na sua poltrona, colocada um pouco atrás e à direita da banqueta na qual ela estava sentada.

- Pensando em coisas tristes?

- Não, até que não ... - respondeu ele. Seria triste pensar, por exemplo, que enquanto ele ia apodrecer na terra ela caminharia ao sol de mãos dadas com outro? Bem? ..

Era verdadeiramente espantosa a nitidez com que imaginava a cena: o piano inesgotável, o ar morno da noite de outubro, tinha ainda de ser outubro com aquele perfume indefinÍvel da primavera. A folhagem parada. E os dois, ombro a ombro, palpitantes e controlados, olhos fixos na escuridão. "LavÍnia 
e Roberto já foram embora?" - perguntaria alguém num sussurro. A resposta sussurrante, pesada de reticências: "Estão lá fora na varanda."

Cruzando os braços com um gesto brusco, ele esfregou o pijama nas axilas molhadas. Disfarçou o gesto e ali ficou alisando as axilas, como se sentisse uma vaga coceira. Cerrou os dentes. Por que nenhum convidado entrava naquele terraço? Por que não se rompiam, com estrépito, as cordas do piano? Ao menos - ao menos! - por que não desabava uma tempestade?

- A noite está firme?

- Firmíssima. Até lua tem.

Ele riu: - Imagine, até isso.

Lavínia apoiou o queixo nas mãos entrelaçadas. Lançou-lhe um olhar entre zombeteiro e inquieto.

- Tomás, que mistério é esse?

- Não tem mistério nenhum, meu amor. Ao contrário, tudo

me parece tão simples ... Mas vamos, não se importe comigo, estou brincando com minhas idéias, aquela brincadeira de idéias conexas, você sabe ... - Teve uma expressão sonolenta. - Mas você não vai se atrasar? Me parece que a reunião é às nove. Não é às nove?

- Ai! essa reunião. Estou com tanta vontade de ir como de me enforcar naquela porta. Vai ser uma chatice, Tomás, as reuniões lá sempre são chatíssimas, tudo igual, os sanduíches de galinha, o uísque ruim, o ponche doce demais ...

- E Chopin, o Bóris não falha nunca. De Chopin você gosta.

- Ah, Tomás, não começa ... Queria tanto ficar aqui com você.

Era verdade, ela preferia ficar, ela ainda o amava. Um amor meio esgarçado, sem alegria. Mas ainda amor. Roberto não passava de uma nebulosa imprecisa e que só seus olhos assinalaram a distância. No entanto, dentro de algumas horas, na aparente candura de uma varanda ... Os acontecimentos precipitandose com uma rapidez de loucura, força de pedra que dormiu milênios e de repente estoura na avalancha. Por incrível que parecesse, estava em suas mãos impedir. Crispou-as dentro do bolso do roupão.

- Quero que você se distraia, Lavínia, sempre será mais divertido do que ficar aqui fechada. E é possível que desta vez não seja assim tão igual. Roberto deve estar lá.

- Roberto?

- Roberto, sim.

Ela arqueou as sobrancelhas. Voltou-se bruscamente: - Mas Roberto está viajando! Já voltou?

- Já, já voltou.

- Como é que você sabe?

- Ele telefonou outro dia, tinha me esquecido de dizer. Te-

lefonou, queria nos visitar. Ficou de aparecer uma noite dessas.

- Imagine ... - murmurou ela, voltando-se de novo para o espelho. Com um fino pincel, pôs-se a delinear os olhos. Falou devagar, sem mover qualquer músculo da face. - Já faz mais de um ano que ele sumiu.

- É, faz mais de um ano.

Paciente Roberto. Pacientíssimo Roberto. - E não se casou por lá?

Ele tentou vê-Ia através do espelho, mas agora ela baixara a cabeça. Mergulhava a ponta do pincel no vidro. Repetiu a pergunta:

- Ele não se casou por lá? Hem? .. Não se casou?

- Não, não se casou.

- Vai acabar solteirão.

Tomás respirou penosamente, de boca aberta. E voltou o rosto para o outro lado. "Meu Deus." Apertou os olhos que foram se reduzindo, concentrados no vaso de gerânios no peitoril da janela. "Eles sabem que nem chegarei a ver este botão desabrochar." Estendeu a mão ávida em direção à planta, colheu furtivamente alguns botões. Esmigalhou-os entre os dedos. Relaxou o corpo. E cerrou os olhos, a fisionomia em paz. Falou num tom suave:

- Você vai chegar atrasada.

- Melhor, ficarei menos tempo.

- Vai me dizer depois se gostou ou não. Mas tem de dizer mesmo ...

- Digo, sim.

Depois ela não the diria mais nada. Seria o primeiro segredo entre os dois, a primeira névoa 
baixando densa, mais densa, separando-os embora caminhassem lado a lado. Viu-a perdida em meio da cerração, o rosto indistinto, a forma irreal. Encolheu-se no fundo da poltrona, uma mão escondida na outra, caramujo gelado rolando na areia, solidão, solidão. "Lavínia, não me abandone já, deixe ao menos eu partir primeiro!" A boca salgada de lágrimas. "Ao menos eu partir primeiro ... " Retesou o tronco, levantou a cabeça. Era cruel. "Não podem fazer isso comigo, eu ainda estou vivo, ouviram bem? Vivo!"

- Ratos.

- Que ratos?

- Ratos, querida, ratos - disse e riu da própria voz aflauta-

da, melíflua. - Já viu um rato bem de perto? Tinha muito rato numa pensão onde morei. De dia ficavam enrustidos, mas de noite se punham insolentes, entravam nos armários, roíam o assoalho, roque-roque ... Eu batia no chão para que parassem e nas primei- ras vezes eles paravam mesmo, mas depois foram se acostumando com minhas batidas e no fim eu podia atirar até uma bomba que continuavam roque-roque-roqueroque ... Mas aí eu também já estava acostumado. Uma noite um deles andou pela minha cara. As patinhas são frias ...

- Que coisa horrível, Tomás!

- Há piores.

A varanda. Lá dentro, o piano, sons melosos escorrendo num Chopin de bairro, as notas acavalando-se no desfibramento de quem pede perdão, "estou tão destreinado, esqueci tudo!" O incentivo ainda mais torpe, "ora, está tão bom, continue!" Mas nem de rastros os sons penetravam realmente no silêncio da varanda, silêncio conivente isolando os dois numa aura espessa. Então Roberto perguntaria naquele tom interessado, tão fraterno: "E o Tomás?" O descarado. À espera da resposta inevitável, o crápula. À espera da confissão que nem a si mesma ela tivera coragem de fazer: "Está cada vez pior." Ele pousaria de leve a mão no seu ombro, como a lhe dizer: "Eu estou ao seu lado, conte comigo." Mas não lhe diria isso, não lhe diria nada, ah, Roberto era oportuno demais para dizer qualquer coisa, ele apenas pousaria a mão no ombro dela e com esse gesto estaria dizendo tudo, "eu te amo, Lavínia, eu te amo."

- Vou molhar os cabelos, estão secos como palha - queixouse ela. E voltou-se para o homem: - Tomás, que tal um copo de leite?

Leite. Ela lhe oferecia leite. Contraiu os maxilares. - Não quero nada.

Diante do espelho, ela deslizou os dedos pelo corpo, arrepanhando o vestido nos quadris. Parecia desatenta, fatigada.

- Está largo demais, quem sabe é melhor ir com o verde ...

- Mas você fica melhor de preto - disse ele, passando a pon-

ta da língua pelos lábios.

Roberto gostaria de vê-Ia assim, magra e de preto, exatamente como naquele jantar. Ela nem se lembrava mais, pelo menos ainda não se lembrava, mas ele revia, como se tivesse sido na véspera aquela noite há quase dez anos.

Dois dias antes do casamento. Lavínia estava assim mesmo, toda vestida de preto. Como única jóia, trazia seu colar de pérolas, precisamente aquele que estava ali, na caixa de cristal. Roberto fora o primeiro a chegar. Estava eufórico: "Que elegância. Lavínia! Como lhe vai bem o preto, nunca te vi tão linda. Se eu fosse você, faria o vestido de noiva preto. E estas pérolas ... Presente do noivo?" Sim, parecia satisfeitíssimo, mas no fundo do seu sorriso, sob a frivolidade dos galanteios, lá no fundo, só ele, Tomás, adivinhava qualquer coisa de sombrio. Não, não era ciúme nem propriamente mágoa, mas qualquer coisa assim com o sabor sarcástico de uma advertência: "Fique com ela, fique com ela por enquanto. Depois veremos." Depois era agora.

A varanda, floreios de Chopin se diluindo no silêncio, vago perfume de folhagem, vago luar, tudo vago. Nítidos, só os dois, tão nítidos. Tão exatos. A conversa fragmentada, mariposa sem alvo deixando aqui e ali o pólen de prata das asas, "e aquele jantar, hem, Lavínia?" Ah, aquele jantar. "Foi há mais de dez anos, não foi?" Ela demoraria para responder. "No final, você lembra?, recitei Geraldy. Eu estava meio bêbado, mas disse o poema inteiro, não encontrei nada melhor pra te saudar, lembra?" Ela ficaria séria. Um tanto perturbada, levaria a mão ao colar de pérolas, gesto tão seu quando não sabia o que diZer: tomava entre os dedos a conta maior do fio e ficava a rodá-Ia devagar. Sim, como não? Lembrava-se perfeitamente, só que o verso adquiria agora um novo sentido, não, não era mais o cumprimento galante para arreliar o noivo. Era a confissão profunda, grave: "Se eu te amasse, se tu me amasses, como nós nos amaríamos!"

- Podia usar o cinto - murmurou ela, voltando a apanhar o vestido nas costas. Dirigiu-se ao banheiro. - 
Paciência, ninguém vai reparar muito em mim.

"Só o Roberto" - ele quis dizer. Esfregou vagarosamente as mãos. Examinou as unhas. "Têm de estar muito limpas", lembrou, entrelaçando os dedos. Levou as mãos ao peito e vagou o olhar pela mesa: a esponja, o perfume, a escova, os grampos, o colar de pérolas ... Através do vidro da caixa, ele via o colar. Ali estavam as pérolas que tinham atraído a atenção de Roberto: rosadas e falsas mas singularmente brilhantes. Voltando ao quarto, ela poria o colar, distraída, inconsciente ainda de tudo quanto a esperava. No entanto, se lhe pedisse, "Lavínia, não vá", se lhe dissesse isto uma única vez, "não vá, fica comigo!"

Vergou o tronco até tocar o queixo nos joelhos, o suor escorrendo ativo pela testa, pelo pescoço, a boca retorcida, "meu Deus!" O quarto rodopiava e numa das voltas sentiu-se arremessado pelo espaço, uma pedra subindo aguda até o limite do grito. E a queda desamparada, "Lavínia, Lavínia!. .. " Fechou os olhos e tombou no fundo da poltrona, tão gelado e tão exausto que só pôde desejar que Lavínia não entrasse naquele instante, não queria que ela o encontrasse assim, a boca ainda escancarada na convulsão da náusea. Puxou o xale até o pescoço. Agora era o cansaço atroz que o fazia sentir-se uma coisa miserável, sem forças sequer para abrir os olhos. "Meu Deus." Passou a mão na testa. E a mão também úmida. "Meu Deus meu Deus meu Deus" - ficou repetindo meio distraidamente. Esfregou as mãos no tecido esponjoso da poltrona, acelerando o movimento. Ninguém podia ajudá-Io, ninguém. Pensou na mãe, na mulherzinha raquítica e esmolambenta que nada tivera na vida, nada a não ser aqueles olhos poderosos, desvendadores. Dela herdara o dom de pressentir. "Eu já sabia", ela costumava dizer quando vinham lhe dar as notícias. "Eu já sabia", ficava repetindo obstinadamente, apertando os olhos de cigana. "Mas se você sabia, por que então não fez alguma coisa para impedir?!" - gritava o marido a sacudi-Ia como um trapo. Ela ficava menorzinha nas mãos do homem, assustadores os olhos de ver na distância. "Fazer o quê? Que é que eu podia fazer senão esperar?"

"Senão esperar", murmurou ele, voltando o olhar para o fio de pérolas enrodilhado na caixa. Sorriu ao ouvir a água escorrendo na torneira.

- Você vai chegar atrasada!

O jorro foi interceptado pelo dique do pente. - Não tem importância, amor.

Num movimento ondulante, ele se pôs na beirada da poltrona, o tronco inclinado, o olhar fixo. - Está se esmerando, heim?

- Nada disso, é que não acerto com o penteado.

- Seus grampos ficaram aqui. Você não quer os grampos?

- disse ele. E, num salto, aproximou-se da mesa, apanhou o colar de pérolas, meteu-o no bolso e voltou à poltrona. - Não vai precisar deles? 


\section{Anexo 3 \\ “Legião estrangeira" - Clarice Lispector}

Se me perguntassem sobre Ofélia e seus pais, teria respondido com o decoro da honestidade: mal os conheci. Diante do mesmo júri ao qual responderia: mal me conheço - e para cada cara de jurado diria com o mesmo límpido olhar de quem se hipnotizou para a obediência: mal vos conheço. Mas às vezes acordo do longo sono e volto-me com docilidade para o delicado abismo da desordem.

Estou tentando falar sobre aquela família que sumiu há anos sem deixar traços em mim, e de quem me ficara apenas uma imagem esverdeada pela distância. Meu inesperado consentimento em saber foi hoje provocado pelo fato de ter aparecido em casa um pinto. Veio trazido por mão que queria ter o gosto de me dar coisa nascida. Ao desengradarmos o pinto, sua graça pegou-nos em flagrante. Amanhã é Natal, mas o momento de silêncio que espero o ano inteiro veio um dia antes de Cristo nascer. Coisa piando por si própria desperta a suavíssima curiosidade que junto de uma manjedoura é adoração. Ora, disse meu marido, e essa agora. Sentira-se grande demais. Sujos, de boca aberta, os meninos se aproximaram. Eu, um pouco ousada, fiquei feliz. O pinto, esse piava. Mas Natal é amanhã, disse acanhado o menino mais velho. Sorríamos desamparados, curiosos.

Mas sentimentos são água de um instante. Em breve - como a mesma água já é outra quando o sol a deixa muito leve, e. já outra quando se enerva tentando morder uma pedra, e outra ainda no pé que mergulha - em breve já não tínhamos no rosto

apenas aura e iluminação. Em torno do pinto aflito, estávamos bons e ansiosos. A meu marido, a bondade deixa ríspido e severo, ao que já nos habituamos; ele se crucifica um pouco. Nos meninos, que são mais graves, a bondade é um ardor. A mim, a bondade me intimida. Daí a pouco a mesma água era outra, e olhávamos contrafeitos, enredados na falta de habilidade de sermos bons. E, a água já outra, pouco a pouco tínhamos no rosto a responsabilidade de uma aspiração, o coração pesado de um amor que já não era mais livre. Também nos desajeitava o medo que o pinto tinha de nós; ali estávamos, e nenhum merecia comparecer a um pinto; a cada piar, ele nos espargia para fora. A cada piar, reduzianos a não fazer nada. A constância de seu pavor acusava-nos de uma alegria leviana que a essa hora nem alegria mais era, era amolação. Passara o instante do pinto, e ele, cada vez mais urgente, expulsava-nos sem nos largar. Nós, os adultos, já teríamos encerrado o sentimento. Mas nos meninos havia uma indignação silenciosa, e a acusação deles é que nada fazíamos pelo pinto ou pela humanidade. A nós, pai e mãe, o piar cada vez mais ininterrupto já nos levara a uma resignação constrangida: as coisas são assim mesmo. Só que nunca tínhamos contado isso aos meninos, tínhamos vergonha; e adiávamos indefinidamente o momento de chamá-Ios e falar claro que as coisas são assim. Cada vez ficava mais difícil, o silêncio crescia, e eles empurravam um pouco o afã com que queríamos lhes dar, em troca, amor. Se nunca havíamos conversado sobre as coisas, muito mais tivemos naquele instante que esconder deles o sorriso que terminou nos vindo com o piar desesperado daquele bico, um sorriso como se a nós coubesse abençoar o fato de as coisas serem assim mesmo, e tivéssemos acabado de abençoá-Ias. 
O pinto, esse piava. Sobre a mesa envernizada ele não ousava um passo, um movimento, ele piava para dentro. Eu não sabia sequer onde cabia tanto terror numa coisa que era só penas. Penas encobrindo o quê? meia dúzia de ossos que se haviam reunido fracos para quê? para o piar de um terror. Em silêncio, em respeito à impossibilidade de nos compreendermos, em respeito à revolta dos meninos contra nós, em silêncio olhávamos sem muita paciência. Era impossível dar-lhe a palavra asseguradora que o fizesse não ter medo, consolar coisa que por ter nascido se espanta. Como prometer-lhe o hábito? Pai e mãe, sabíamos quão breve seria a vida do pinto. Também este sabia, do modo como as coisas vivas sabem: através do susto profundo.

E enquanto isso, o pinto cheio de graça, coisa breve e amarela. Eu queria que também ele sentisse a graça de sua vida, assim como já pediram de nós, ele que era a alegria dos outros, não a própria. Que sentisse que era gratuito, nem sequer necessário - um dos pintos tem que ser inútil - só nascera para a glória de Deus, então fosse a alegria dos homens. Mas era amar o nosso amor querer que o pinto fosse feliz somente porque o amávamos. Eu sabia também que só mãe resolve o nascimento, e o nosso era amor de quem se compraz em amar: eu me revolvia na graça de me ser dado amar, sinos, sinos repicavam porque sei adorar. Mas o pinto tremia, coisa de terror, não de beleza.

O menino menor não suportou mais: - Você quer ser a mãe dele?

Eu disse que sim, em sobressalto. Eu era a enviada junto àquela coisa que não compreendia a minha única linguagem: eu estava amando sem ser amada. A missão era falível, e os olhos de quatro meninos aguardavam com a intransigência da esperança o meu primeiro gesto de amor eficaz. Recuei um pouco, sorrindo toda solitária, olhei para minha família, queria que eles sorrissem. Um homem e quatro meninos me fitavam, incrédulos e confiantes. Eu era a mulher da casa, o celeiro. Por que a impassibilidade dos cinco, não entendi. Quantas vezes teria eu falhado para que, na minha hora de timidez, eles me olhassem. Tentei isolar-me do desafio dos cinco homens para também eu esperar de mim e lembrar-me de como é o amor. Abri a boca, ia dizer-Ihes a verdade: não sei como.

Mas se me viesse de noite uma mulher. Se ela segurasse no colo o filho. E dissesse: cure meu filho. Eu diria: como é que se faz? Ela responderia: cure meu filho. Eu diria: também não sei. Ela responderia: cure meu filho. Então - então porque não sei fazer nada e porque não me lembro de nada e porque é de noite - então estendo a mão e salvo uma criança. Porque é de noite, porque estou sozinha na noite de outra pessoa, porque este silêncio é muito grande para mim, porque tenho duas mãos para sacrificar a melhor delas e porque não tenho escolha.

Então estendi a mão e peguei o pinto.

Foi nesse instante que revi Ofélia. E nesse instante lembreime de que fora a testemunha de uma menina.

Mais tarde lembrei-me de como a vizinha, mãe de Ofélia, era trigueira como uma hindu. Tinha olheiras arroxeadas que a embelezavam muito e davam-lhe um ar fatigado que fazia os homens a olharem uma segunda vez. Um dia, no banco da praça, enquanto as crianças brincavam, ela me dissera com aquela sua cabeça obstinada de quem olha para o deserto: "Sempre quis tirar um curso de enfeitar bolos" . Lembrei-me de que o marido - trigueiro também, como se se tivessem escolhido pela secura da cor - queria subir na vida através de seu ramo de negócios: gerência de hotéis ou dono mesmo, nunca entendi bem. $\mathrm{O}$ que lhe dava uma dura polidez. Quando éramos forçados no elevador a contato mais prolongado, ele aceitava a troca de palavras num tom de arrogância que trazia de lutas maiores. Até chegarmos ao décimo andar, a humildade a que sua frieza me forçara já o amansara um pouco; talvez chegasse em casa mais bem servido. Quanto à mãe de Ofélia, ela temia que à força de morarmos no mesmo andar houvesse intimidade e, sem saber que também eu me resguardava, evitava-me. A única intimidade fora a do banco do jardim, onde, com olheiras e boca fina, falara sobre enfeitar bolos. Eu não soubera o que retrucar e terminara dizendo para que soubesse que eu gostava dela, que o curso dos bolos me agradaria. Esse único momento mútuo afastara-nos ainda mais, por receio de um abuso de compreensão. A mãe de Ofélia chegara mesmo a ser grosseira no elevador: no dia seguinte eu estava com um dos meninos pela mão, o elevador descia devagar, e eu, apressa pelo silêncio que, à outra, fortificava - dissera num tom de agrado que no mesmo istante também a mim repugnara:

- Estamos indo para a casa da avó dele. E ela, para meu espanto:

- Não perguntei nada, nunca me meto na vida dos vizinhos.

- Ora, disse eu baixo.

O que, ali mesmo no elevador, me fizera pensar que eu estava pagando por ter sido sua confidente de um minuto no banco do jardim. O que, por sua vez, me fizera pensar que ela talvez julgasse me ter confiado 
mais do que na realidade confiara. O que, por sua vez, me fizera pensar se na verdade ela não me dissera mais do que nós duas percebêramos. Enquanto o elevador continuava a descer e parar, eu reconstituíra seu ar insistente e sonhador no banco do jardim - e olhara com olhos novos para a beleza altaneira da mãe de Ofélia. "Não contarei a ninguém que você quer enfeitar bolos", pensei olhando-a rapidamente.

O pai agressivo, a mãe se guardando. Família soberba.

Tratavam-me como se eu já morasse no futuro hotel deles e ofendesse-os com o pagamento que exigiam. Sobretudo tratavamme como se nem eu acreditasse, nem eles pudessem provar quem eles eram. E quem eram eles? indagava-me às vezes. Por que a bofetada que estava impressa no rosto deles, por que a dinastia exilada? E tanto não me perdoavam que eu agia não-perdoada: se os encontrava na rua, fora do setor que me era circunscrito, sobressaltava-me, surpreendida em delito: recuava para eles passarem, dava-Ihes a vez - os três trigueiros e bem-vestidos passavam como se fossem à missa, aquela família que vivia sob o signo de um orgulho ou de um martírio oculto, arroxeados como flores da Paixão. Família antiga, aquela.

Mas o contato se fez através da filha. Era uma menina belíssima, com longos cachos duros, Ofélia, com olheiras iguais às da mãe, as mesmas gengivas um pouco roxas, a mesma boca fina de quem se cortou. Mas essa, a boca, falava. Deu· para aparecer em casa. Tocava a campainha, eu abria a portinhola, não via nada, ouvia uma voz decidida:

- Sou eu, Ofélia Maria dos Santos Aguiar.

Desanimada, eu abria a porta. Ofélia entrava. A visita era para mim, meus dois meninos daquele tempo eram pequenos demais para sua sabedoria pausada. Eu era grande e ocupada, mas era para mim a visita: com uma atenção toda interior, como se para tudo houvesse um tempo, levantava com cuidado a saia de babados, sentava-se, ajeitava os babados - e só então me olhava. Eu, que então copiava o arquivo do escritório, eu trabalhava e ouvia. Ofélia, ela dava-me conselhos. Tinha opinião formada a respeito de tudo. Tudo o que eu fazia era um pouco errado, na sua opinião. Dizia "na minha opinião" em tom ressentido, como se eu lhe devesse ter pedido conselhos e, já que eu não pedia, ela dava. Com seus oito anos altivos e bem vividos, dizia que na sua opinião eu não criava bem os meninos; pois meninos quando se dá a mão querem subir na cabeça. Banana não se mistura com leite. Mata. Mas é claro a senhora faz o que quiser; cada um sabe de si. Não era mais hora de estar de robe; sua mãe mudava de roupa logo que saía da cama, mas cada um termina levando a vida que quer. Se eu explicava que era porque ainda não tomara banho. Ofélia ficava quieta, olhando-me atenta. Com alguma suavidade, então, com alguma paciência, acrescentava que não era hora de ainda não ter tomado banho. Nunca era minha a última palavra. Que última palavra poderia eu dar quando ela me dizia: empada de legume não tem tampa. Uma tarde numa padaria vi-me inesperadamente diante da verdade inútil: lá estava sem tampa uma fila de empadas de legumes. "Mas eu lhe avisei", ouvi-a como se ela estivesse presente. Com seus cachos e babados, com sua delicadeza firme, que era porque ainda não tomara banho. Ofélia fivalia é que dizia muita tolice também, o que, no meu desalento, me fazia sorrir desesperada.

A pior parte da visitação era a do silêncio. Eu erguia os olhos da máquina, e não saberia há quanto tempo Ofélia me olhava em silêncio. $\mathrm{O}$ que em mim pode atrair essa menina? exasperava-me eu. Uma vez, depois de seu longo silêncio, dissera-me tranqüila: a senhora é esquisita. E eu, atingida em cheio no rosto sem cobertura - logo no rosto que sendo o nosso avesso é coisa tão sensível- eu, atingida em cheio, pensara com raiva: pois vai ver que é esse esquisito mesmo que você procura. Ela que estava toda coberta, e tinha mãe coberta, e pai coberto.

Eu ainda preferia, pois, conselho e crítica. Já menos tolerável era o seu hábito de usar a palavra portanto com que ligava as frases numa concatenação que não falhava. Dissera-me que eu comprara legumes demais na feira - portanto - não iam caber na geladeira pequena e - portanto - murchariam antes da próxima feira. Dias depois eu olhava os legumes murchos. Portanto, sim. Outra vez vira menos legumes espalhados pela mesa da cozinha, eu que disfarçadamente obedecera. Ofélia olhara, olhara. Parecia prestes a J1,ão dizer nada. Eu esperava de pé, agressiva, muda. Ofélia dissera sem nenhuma ênfase:

- É pouco até a feira que vem.

Os legumes acabaram pelo meio da semana. Como é que ela sabe? perguntava-me eu curiosa. "Portanto" seria a resposta tal- vez. Por que eu nunca, nunca sabia? Por que sabia ela de tudo, por que era a terra tão famílíar a ela, e eu sem cobertura? Portanto? Portanto. 
Uma vez Ofélía errou. Geografia disse sentada defronte a mim com os dedos cruzados no colo $\sim$ é um modo de estudar. Não chegava a ser erro, era mais um leve estrabismo de pensamento $\sim$ mas para mim teve a graça de uma queda, e antes que o instante passasse, eu por dentro lhe disse: é assim mesmo que se faz, isso! vá devagar assim, e um dia vai ser mais fácil ou mais difícil para você, mas é assim, vá errando, bem, bem devagar.

Uma manhã, no meio de sua conversa, avisou-me autoritária: "Vou em casa ver uma coisa mas volto logo". Arrisquei: "Se você está muito ocupada, não precisa voltar". Ofélia olhou-me muda, inquisitiva. "Existe uma menina muito antipática", pensei bem claro para que ela visse a frase toda exposta no meu rosto. Ela sustentou o olhar. O olhar onde $\sim$ com surpresa e desolação $\sim$ vi fidelidade paciente confiança em mim e o silêncio de quem nunca falou. Quando é que eu lhe jogara um osso para que ela me seguisse muda pelo resto da vida? Desviei os olhos. Ela suspirou tranqüila. E disse com maior decisão ainda: "Volto logo". Que é que ela quer? agitei-me $\sim$ por que atraio pessoas que nem sequer gostam de mim?

Uma vez, quando Ofélia estava sentada, tocaram a campainha. Fui abrir e deparei com a mãe de Ofélia. Vinha protetora, exigente:

$\sim$ Por acaso Ofélia Maria está aí?

$\sim$ Está, escusei-me como se a tivesse raptado.

$\sim$ Não faça mais isso $\sim$ disse ela para Ofélia num tom que me era dirigido; depois voltou-se para mim e, subitamente ofendida: Desculpe o incômodo.

$\sim$ Nem pense nisso, essa menina é tão inteligente.

A mãe olhou-me em leve surpresa mas a suspeita passoulhe pelos olhos. E neles eu li: que é que você quer dela?

$\sim$ Já proibi Ofélia Maria de incomodar a senhora, disse agora em desconfiança aberta. E segurando firme a mão da menina para levá-la, parecia defendê-Ia contra mim. Com uma sensação de decadência, espiei pela portinhola entreaberta sem ruídos: lá iam as duas pelo corredor que levava ao apartamento delas, a mãe abrigando a fillha com murmúrios de repreensão amorosa, a filha impassível a fremir cachos e babados. Ao fechar a portinhola percebi que ainda não mudara de roupa e, portanto, assim fora vista pela mãe que mudava de roupa ao sair da cama. Pensei com alguma desenvoltura: bem, agora a mãe me despreza, portanto estou livre de a menina voltar.

Mas voltava, sim. Eu era atraente demais para aquela criança.

Tinha defeitos bastantes para seus conselhos, era terreno para o desenvolvimento de sua severidade, já me tornara o domínio daquela minha escrava: ela voltava, sim, levantava os babados, sentava-se.

Por essa ocasião, sendo perto da Páscoa, a feira estava cheia de pintos, e eu trouxe um para os meninos. Brincamos, depois ele ficou pela cozinha, os meninos pela rua. Mais tarde Ofélia aparecia para a visita. Eu batia a máquina, de vez em quando aquiescia distraída. A voz igual da menina, voz de quem fala de cor, me entontecia um pouco, entrava por entre as palavras escritas; ela dizia, ela dizia.

Foi quando me pareceu que de repente tudo parara. Sentindo falta do suplício, olhei-a enevoada. Ofélia Maria estava de cabeça a prumo, com os cachos inteiramente imobilizados.

- Que é isso, disse.

- Isso o quê?

- Isso! disse inflexível.

- Isso?

Ficaríamos indefinidamente numa roda de "isso?" e "isso!", não fosse a força excepcional daquela criança, que, sem uma palavra, apenas com a extrema autoridade do olhar, me obrigasse a ouvir o que ela própria ouvia. No silêncio da atenção a que ela me forçara, ouvi finalmente o fraco piar do pinto na cozinha.

- É o pinto.

- Pinto? disse desconfiadíssima.

- Comprei um pinto, respondi resignada.

- Pinto! repetiu como se eu a tivesse insultado.

- Pinto.

E nisso ficaríamos. Não fosse certa coisa que vi e que antes nunca vira.

O que era? Mas, o que fosse, não estava mais ali. Um pinto faiscara um segundo em seus olhos e neles submergira para nunca ter existido. E a sombra se fizera. Uma sombra profunda cobrindo a terra. Do instante em que involuntariamente sua boca estremecendo quase pensara "eu também quero", desse instante 
a escuridão se adensara no fundo dos olhos num desejo retrátil que, se tocassem, mais se fecharia como folha de dormideira. E que recuava diante do impossível, o impossível que se aproximara e, em tentação, fora quase dela: o escuro dos olhos vacilou como um ouro. Uma astúcia passou-lhe então pelo rosto - se eu não estivesse ali, por astúcia, ela roubaria qualquer coisa. Nos olhos que pestanejaram à dissimulada sagacidade, nos olhos a grande tendência à rapina. Olhou-me rápida, e era a inveja, você tem tudo, e a censura, porque não somos a mesma e eu terei um pinto, e a cobiça - ela me queria para ela. Devagar fui me reclinando no espaldar da cadeira, sua inveja que desnudava minha pobreza, e deixava minha pobreza pensativa; não estivesse eu ali, e ela roubava minha pobreza também; ela queria tudo. Depois que o tremor da cobiça passou, o escuro dos olhos sofreu todo: não era somente a um rosto sem cobertura que eu a expunha, agora eu a expusera ao melhor do mundo: a um pinto. Sem me verem, seus olhos quentes me fitavam numa abstração intensa que se punha em íntimo contato com minha intimidade. Alguma coisa acontecia que eu não conseguia entender a olho nu. E de novo o desejo voltou. Dessa vez os olhos se angustiaram como se nada pudessem fazer com o resto do corpo que se desprendia independente. E mais se alargavam, espantados com o esforço físico da decomposição que dentro dela se fazia. A boca delicada ficou um pouco infantil, de um roxo pisado. Olhou para o teto - as olheiras davam-lhe um ar de martírio supremo. Sem me mexer, eu a olhava. Eu sabia de grande incidência de mortalidade infantil. Nela a grande pergunta me envolvia: vale a pena? Não sei, disse-lhe minha quietude cada vez maior, mas é assim. Ali, diante de meu silêncio, ela estava se dando ao processo, e se me perguntava a grande pergunta, tinha que ficar sem resposta. Tinha que se dar - por nada. Teria que ser. E por nada. Ela se agarrava em si, não querendo. Mas eu esperava. Eu sabia que nós somos aquilo que tem de acontecer. Eu só podia servir-lhe a ela de silêncio. E, deslumbrada de desentendimento, ouvia bater dentro de mim um coração que não era o meu. Diante de meus olhos fascinados, ali diante de mim, como um ectoplasma, ela estava se transformando em criança.

Não sem dor. Em silêncio eu via a dor de sua alegria difícil.

A lenta cólica de um caracol. Ela passou devagar a língua pelos lábios finos. (Me ajuda, disse seu corpo na bipartição penosa. Estou ajudando, respondeu minha imobilidade.) A agonia lenta. Ela estava engrossando toda, a deformar-se com lentidão. Por momentos os olhos tornavam-se puros cílios, numa avidez de ovo. E a boca de uma fome trêmula. Quase sorria então, como se estendida numa mesa de operação dissesse que não estava doendo tanto. Ela não me perdia de vista: havia marca de pés que ela não via, por ali alguém já tinha andado, e ela adivinhava que eu tinha andado muito. Mais e mais se deformava, quase idêntica a si mesma. Arrisco? deixo eu sentir?, perguntavase nela. Sim, respondeu-se por mim.

E o meu primeiro sim embriagou-me. Sim, repetiu meu silêncio para o dela, sim. Como na hora de meu filho nascer eu lhe dissera: sim. Eu tinha a ousadia de dizer sim.a Ofélia, eu que sabia que também se morre em criança sem ninguém perceber. Sim, repeti embriagada, porque o perigo maior não existe: quando se vai, se vai junto, você mesma sempre estará; isso, isso você levará consigo para o que for ser.

A agonia de seu nascimento. Até então eu nunca vira a coragem. A coragem de ser o outro que se é, a de nascer do próprio parto, e de largar no chão o corpo antigo. E sem lhe terem respondido se valia a pena. "Eu", tentava dizer seu corpo molhado pelas águas. Suas núpcias consigo mesma.

Ofélia perguntou devagar, com recato pelo que lhe acontecia: - É um pinto?

Não olhei para ela.

- É um pinto, sim.

Da cozinha vinha o fraco piar. Ficamos em silêncio como se Jesus tivesse nascido. Ofélia respirava, respirava.

- Um pintinho? certificou-se em dúvida.

- Um pintinho, sim, disse eu guiando-a com cuidado para a vida.

- Ah, um pintinho, disse meditando.

- Um pintinho, disse eu sem brutalizá-Ia.

Já há alguns minutos eu me achava diante de uma criança.

Fizera-se a metamorfose. - Ele está na cozinha.

- Na cozinha? repetiu fazendo-se de desentendida.

- Na cozinha, repeti pela primeira vez autoritária, sem acres- 
centar mais nada.

- Ah, na cozinha, disse Ofélia muito fingida, e olhou para o teto.

Mas ela sofria. Com alguma vergonha notei afinal que estava me vingando. A outra sofria, fingia, olhava para o teto. A boca, as olheiras.

- Você pode ir pra cozinha brincar com o pintinho.

- Eu ... ? perguntou sonsa.

- Mas só se você quiser.

Sei que deveria ter mandado, para não expô-Ia à humilhação de querer tanto. Sei que não lhe deveria ter dado a escolha, e então ela teria a desculpa de que fora obrigada a obedecer. Mas naquele momento não era por vingança que eu lhe dava o tormento da liberdade. É que aquele passo, também aquele passo ela deveria dar sozinha. Sozinha e agora. Ela é que teria de ir à montanha. Por que confundia-me eu - por que estou tentando soprar minha vida na sua boca roxa? por que estou lhe dando uma respiração? como ouso respirar dentro dela, se eu mesma ... somente para que ela ande, estou lhe dando os passos penosos? sopro-lhe minha .vida só para que um dia, exausta, ela por um instante sinta como se a montanha tivesse caminhado até ela?

Teria eu o direito. Mas não tinha escolha. Era uma emergência como se os lábios da menina estivessem cada vez mais roxos. - Só vá ver o pintinho se você quiser, repeti então com a extrema dureza de quem salva.

Ficamos nos defrontando, dissemelhantes, corpo separado de corpo; somente a hostilidade nos unia. Eu estava seca e inerte na cadeira para que a menina se fizesse dor dentro de outro ser, firme para que ela lutasse dentro de mim; cada vez mais forte à medida que Ofélia precisasse me odiar e precisasse que eu resistisse ao sofrimento de seu ódio. Não posso viver isso por você

- disse-lhe minha frieza. Sua luta se fazia cada vez mais próxima e em mim, como se aquele indivíduo que nascera extraordinariamente dotado de força estivesse bebendo de minha fraqueza. Ao me usar ela me machucava com sua força; ela me arranhava ao tentar agarrar-se às minhas paredes lisas. Afinal sua voz soou em baixa e lenta raiva:

- Pois vou ver o pinto na cozinha.

- Vá sim, disse eu devagar.

Retirou-se pausada, procurava manter a dignidade das costas. Da cozinha voltou imediatamente estava espantada, sem

pudor, mostrando na mão o pinto, e numa perplexidade que me indagava toda com os olhos:

- É um pintinho! disse.

Olhou-o na mão que se estendia, olhou-me, olhou de novo a mão - e de súbito encheu-se de um nervoso e de uma preocupação que me envolveram automaticamente em nervoso e preocupação.

- Mas é um pintinho! disse, e imediatamente a censura passou-lhe pelos olhos como se eu não lhe tivesse dito quem piava.

Ri. Ofélia olhou-me, ultrajada. E de repente - de repente riu.

Ambas então rimos, um pouco agudas.

Depois que rimos, Ofélia pôs o pinto no chão para andar.

Se ele corria, ela ia atrás, parecia só deixá-1 o autônomo para sentir saudade; mas se ele se encolhia, pressurosa ela o protegia, com pena de ele estar sob o seu domínio, "coitado dele, ele é meu"; e quando o segurava, era com mão torta pela delicadeza - era o amor, sim, o tortuoso amor. Ele é muito pequeno, portanto precisa é de muito trato, a gente não pode fazer carinho porque tem os perigos mesmo; não deixe pegarem nele à toa, a senhora faz o que quiser, mas milho é grande demais para o biquinho aberto dele; porque ele é molezinho, coitado, tão novo, portanto a senhora não pode deixar seus filhos fazerem carinho nele; só eu sei que carinho ele gosta; ele escorrega à toa, portanto chão de cozinha não é lugar para pintinho.

Há muito tempo eu tentava de novo bater a máquina procurando recuperar o tempo perdido e Ofélia me embalando, e aos poucos falando só para o pintinho, e amando de amor. Pela primeira vez me largara, ela não era mais eu. Olhei-a, toda de ouro

que ela estava, e o pinto todo de ouro, e os dois zumbiam como roca e fuso. Também minha liberdade afinal, e sem ruptura; adeus, e eu sorria de saudade.

Muito depois percebi que era comigo que Ofélia falava. - Acho - acho que vou botar ele na cozinha.

- Pois vá.

Não vi quando foi, não vi quando voltou. Em algum momento, por acaso e distraída, senti há 
quanto tempo havia silêncio. Olhei-a um instante. Estava sentada, de dedos cruzados no colo. Sem saber exatamente por que, olhei-a uma segunda vez:

- Que é?

- Eu ...?

- Está sentindo alguma coisa?

- Eu ...?

- Quer ir no banheiro?

- Eu ...?

Desisti, voltei à máquina. Algum tempo depois ouvi a voz: - Vou ter que ir para casa.

- Está certo.

- Se a senhora deixar.

Olhei-a em surpresa:

- Ora, se você quiser...

- Então, disse, então eu vou.

Foi andando devagar, cerrou a porta sem ruído. Fiquei olhando a porta fechada. Esquisita é você, pensei. Voltei ao trabalho.

Mas não conseguia sair da mesma frase. Bem - pensei impaciente olhando o relógio - e agora o que é? Fiquei me indagando sem gosto, procurando em mim mesma o que poderia estar me interrompendo. Quando já desistia, revi uma cara extremamente quieta: Ofélia. Menos que uma idéia passou-me então pela cabeça e, ao inesperado, esta se inclinou para ouvir melhor o que eu sentia. Devagar empurrei a máquina. Relutante fui afastando devagar as cadeiras do caminho. Até parar devagar à porta da cozinha. No chão estava o pinto morto. Ofélia! chamei num impulso pela menina fugi da.

A uma distância infinita eu via o chão. Ofélia, tentei eu inutilmente atingir à distância o coração da menina calada. Oh, não se assuste muito! às vezes a gente mata por amor, mas juro que um dia a gente esquece, juro! a gente não ama bem, ouça, repeti, como se pudesse alcançá-Ia antes que, desistindo de servir ao verdadeiro, ela fosse altivamente servir ao nada. Eu que não me lembrara de lhe avisar que sem o medo havia o mundo. Mas juro que isso é a respiração. Eu estava muito cansada, senteime no banco da cozinha.

Onde agora estou, batendo devagar o bolo de amanhã. Sentada, como se durante todos esses anos eu tivesse com paciência esperado na cozinha. Embaixo da mesa, estremece o pinto de hoje. O amarelo é o mesmo, o bico é o mesmo. Como na Páscoa nos é prometido, em dezembro ele volta. Ofélia é que não voltou: cresceu. Foi ser a princesa hindu por quem no deserto sua tribo esperava. 


\section{Anexo 4 \\ “O amor acaba" - Paulo Mendes Campos}

O amor acaba. Numa esquina, por exemplo, num domingo de lua nova, depois de teatro e silêncio; acaba em cafés engordurados, diferentes dos parques de ouro onde começou a pulsar; de repente, ao meio do cigarro que ele atira de raiva contra um automóvel ou que ela esmaga no cinzeiro repleto, polvilhando de cinzas o escarlate das unhas; na acidez da aurora tropical, depois duma noite votada à alegria póstuma, que não veio; e acaba o amor no desenlace das mãos no cinema, como tentáculos saciados, e elas se movimentam no escuro como dois polvos de solidão; como se as mãos soubessem antes que o amor tinha acabado; na insônia dos braços luminosos do relógio; e acaba o amor nas sorveterias diante do colorido iceberg, entre os frisos de alumínio e espelhos monótonos; e no olhar do cavaleiro errante que passou pela pensão; às vezes acaba o amor nos braços torturados de Jesus, filho crucificado de todas as mulheres; mecanicamente, no elevador, como se lhe faltasse energia; no andar diferente da irmã dentro de casa o amor pode acabar; na epifania da pretensão ridícula dos bigodes; nas ligas, nas cintas, nos brincos e nas silabadas femininas; quando a alma se habitua às províncias empoeiradas da Ásia, onde o amor pode ser outra coisa, o amor pode acabar; na compulsão da simplicidade simplesmente; no sábado, depois de três goles mornos de gim à beira da piscina; no filho tantas vezes semeado, às vezes vingado por alguns dias, mas que não floresceu, abrindo parágrafos de ódio inexplicável entre o pólen e o gineceu de duas flores; em apartamentos refrigerados, atapetados, aturdidos de delicadezas, onde há mais encanto que desejo; e o amor acaba na poeira que vertem os crepúsculos, caindo imperceptível no beijo de ir e vir; em salas esmaltadas com sangue, suor e desespero; nos roteiros do tédio para o tédio, na barca, no trem, no ônibus, ida e volta de nada para nada; em cavernas de sala e quarto conjugados o amor se eriça e acaba; no inferno o amor não começa; na usura o amor se dissolve; em Brasília o amor pode virar pó; no Rio, frivolidade; em Belo Horizonte, remorso; em São Paulo, dinheiro; uma carta que chegou depois, o amor acaba; uma carta que chegou antes, e o amor acaba; na descontrolada fantasia da libido; às vezes acaba na mesma música que começou, com o mesmo drinque, diante dos mesmos cisnes; e muitas vezes acaba em ouro e diamante, dispersado entre astros; e acaba nas encruzilhadas de Paris, Londres, Nova Iorque; no coração que se dilata e quebra, e o médico sentencia imprestável para o amor; e acaba no longo périplo, tocando em todos os portos, até se desfazer em mares gelados; e acaba depois que se viu a bruma que veste o mundo; na janela 
que se abre, na janela que se fecha; às vezes não acaba e é simplesmente esquecido como um espelho de bolsa, que continua reverberando sem razão até que alguém, humilde, o carregue consigo; às vezes o amor acaba como se fora melhor nunca ter existido; mas pode acabar com doçura e esperança; uma palavra, muda ou articulada, e acaba o amor; na verdade; o álcool, de manhã, de tarde, de noite; na floração excessiva da primavera; no abuso do verão; na dissonância do outono, no conforto do inverno; em todos os lugares o amor acaba; a qualquer hora o amor acaba; por qualquer motivo o amor acaba; para recomeçar em todos os lugares e a qualquer minuto o amor acaba.

\section{Anexo 5}

\section{Marina Colasanti}

\section{Prova de Amor}

"Meu bem, deixa crescer a barba para me agradar", pediu ele.

E ela, num supremo esforço de amor, começou a fiar dentro de si, e a laboriosamente expelir aqueles novos pêlos, que na pele fechada feriam caminho.

Mas quando, afinal, doce barba cobriu-lhe o rosto, e com orgulho expectante entregou sua estranheza àquele homem: "Você não é mais a mesma", disse ele.

E se foi.

\section{A honra passada a limpo}

Sou compulsiva, eu sei. Limpeza e arrumação.

Todos os dias boto a mesa, tiro a mesa. Café, almoço, jantar. E pilhas de louça na pia, e espumas redentoras.

Todos os dias entro nos quartos, desfaço camas, desarrumo berços, lençóis ao alto como velas. Para tudo arrumar depois, alisando colchas de crochê.

Sou caprichosa, eu sei. Desce o pó sobre os móveis. Que eu colho na flanela. Escurecem-se as pratas. Que eu esfrego com a camurça. A aranha tece que eu enxoto. A traça rói. Que eu esmago. O cupim voa. Que eu afogo na água da tigela sob a luz.

E de vassoura em punho gasto tapetes persas.

Sou perseverante, eu sei. À mesa que ponho ninguém senta. Nas camas que arrumo ninguém dorme. Não há ninguém nesta casa vazia há tanto tempo.

Mas sem tarefas domésticas, como preencher de feminina honradez a minha vida? 


\section{Anexo 6}

\section{Canto final : Foi cantada realmente somente a $1^{\text {a }}$ estrofe e criamos mais uma, que está no final.}

O AMOR ACABA

O amor acaba

É vela que se apaga

Por força da sorte

Ou por vento forte

Esvai-se enfim.

O amor acaba

É como uma taça

Que ao chão se estilhaça

Sem forma e sem graça

No seu fim.

O amor acaba

Pois tem seu prazo

Que por força do acaso

Como um lindo vaso

Que ao cair do terraço

Tem seu fim.

O amor acaba

É pelo cansaço

Pela vida esquecida

Ou talvez não vivida

É sempre assim.
O amor é flor carmim

Que na alvorada

Colore a passarada

Mas a noite chega ao fim.

O amor acaba

Como acaba a rosa

Como acaba o cravo

E também o Jasmim.

O amor acaba

O amor acaba sim

O amor acaba

Pra você e pra mim.

O amor acaba

$\mathrm{Na}$ vida ao passar

O amor acaba

Pra recomeçar.

O amor acaba

Como um lago que se abala

Por pedra atirada

De alguém a passar

O amor acaba

Pra recomeçar. 
Parte acrescentada por nós

$O$ amor acaba.

Por isso ou por nada.

Gira, recomeça,

Renova a promessa:

Não ter fim.

\section{ILUSTRAÇÕES}


1 - ATIVIDADES TEATRAIS NO ÁVILA
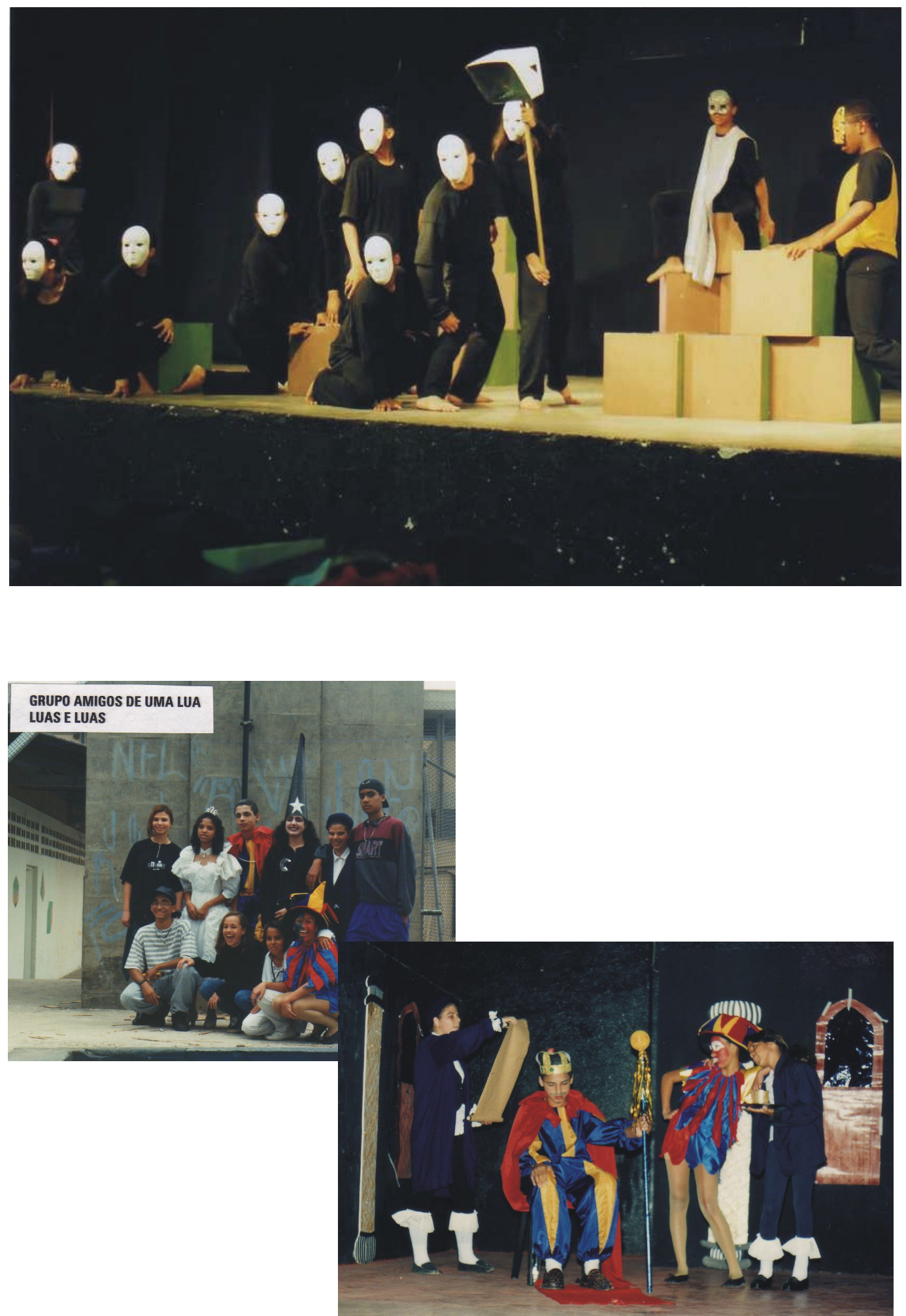


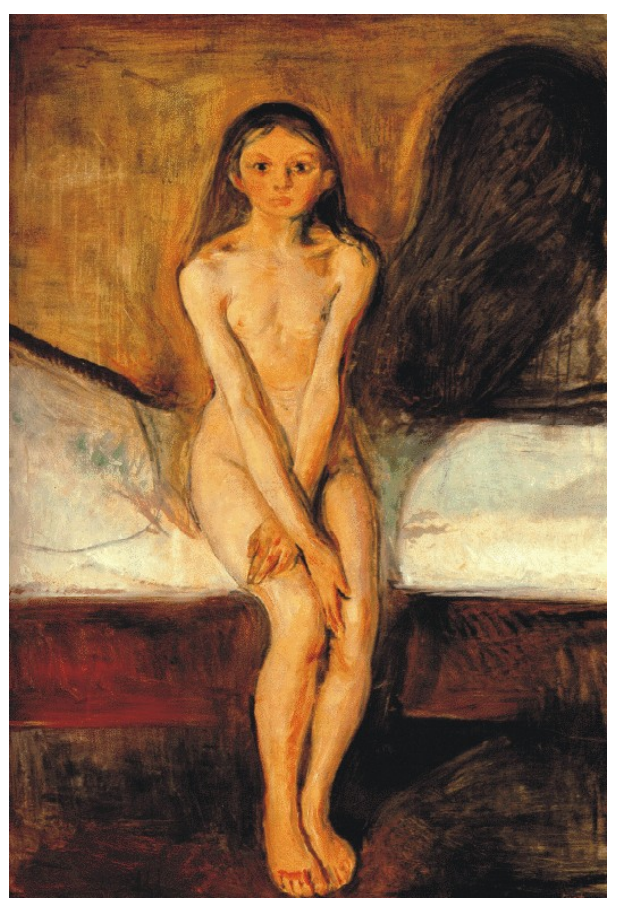

"PUBERDADE" - EDVARD MUNCH

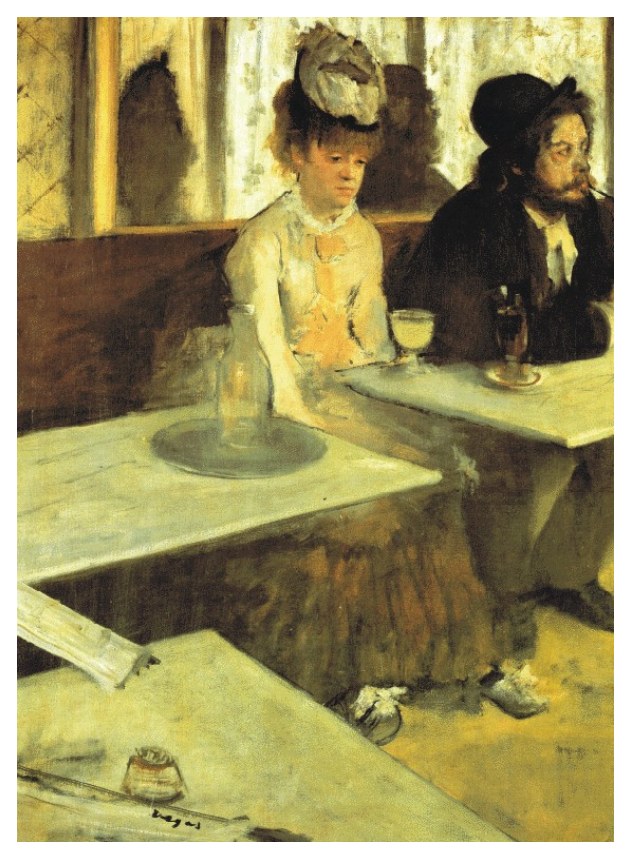

“O COPO DE ABSINTO” - EDGAR DEGAS

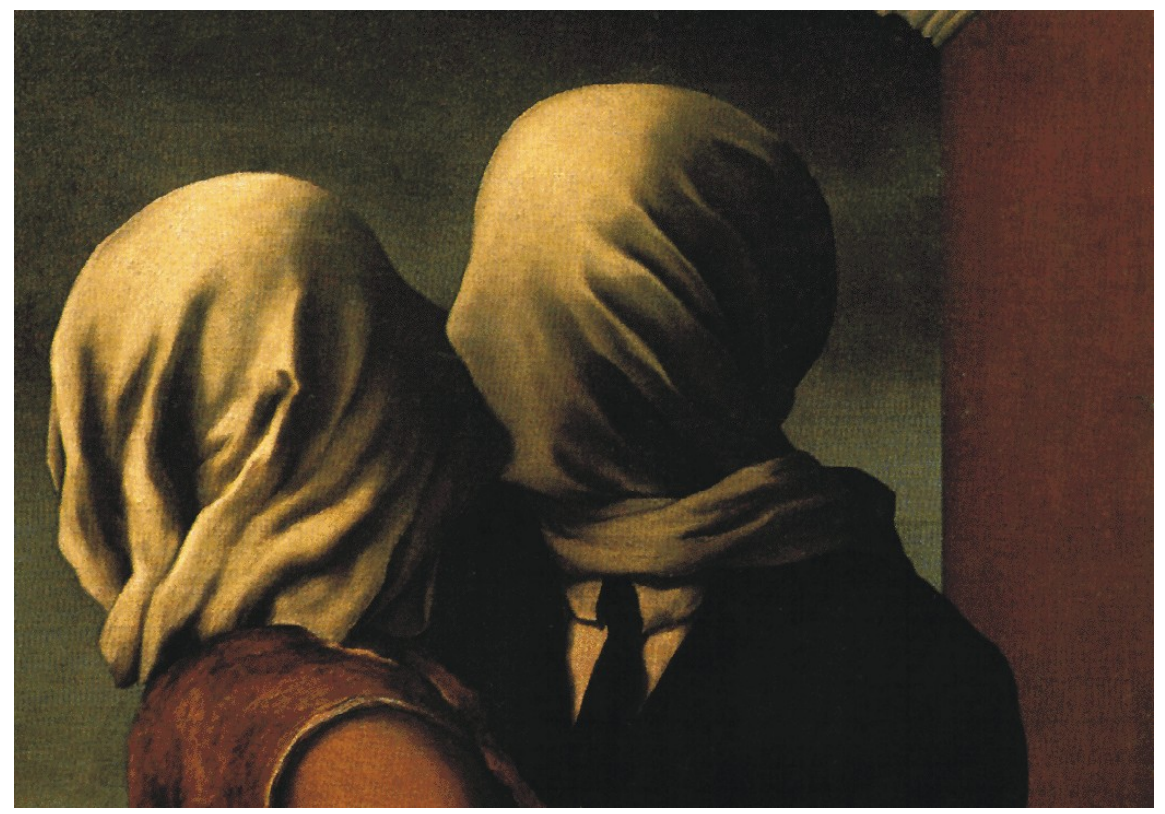

"OS AMANTES" - RENÉ MAGRITTE 
3 - FILME "SÃO BERNADO"
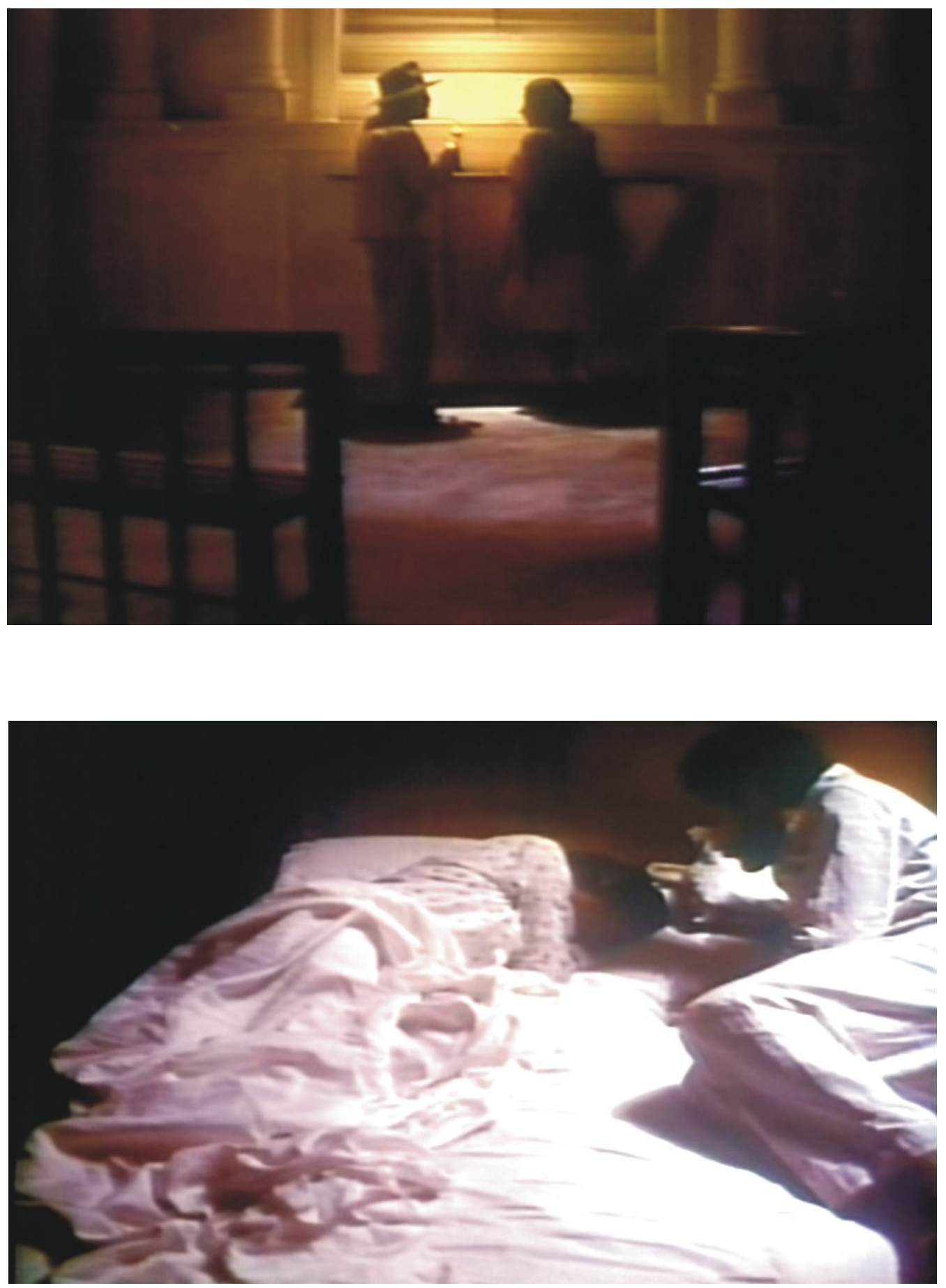
4 - CARYBÉ

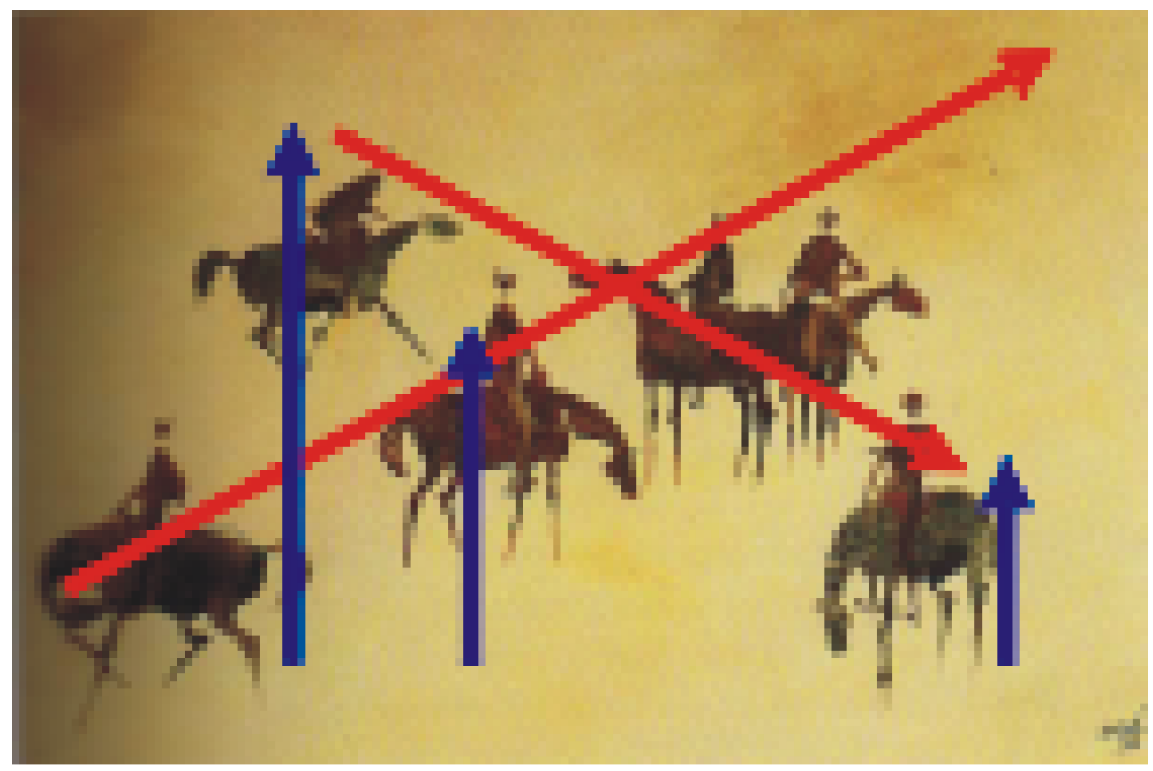

“A PAUSA DOS VAQUEIROS"

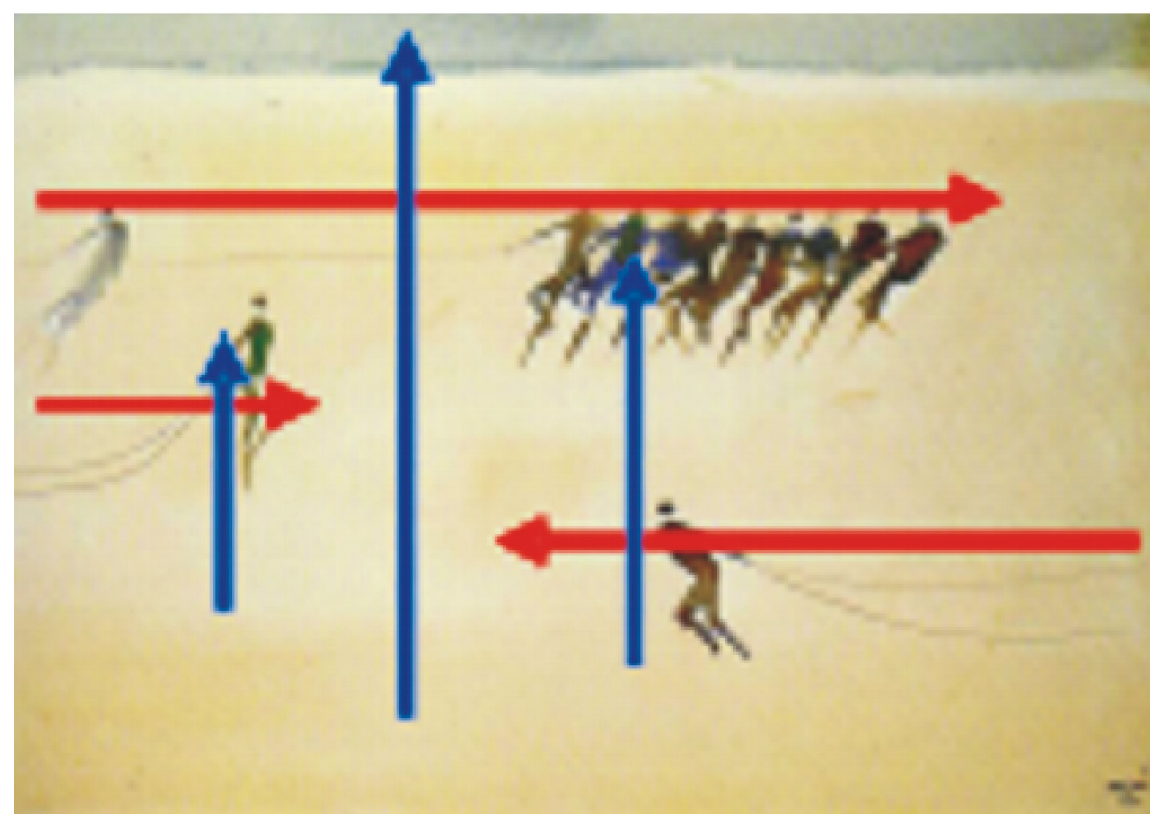

"A PESCA DE CHARREL" 
5 - REFERÊNCIAS E RESULTADOS
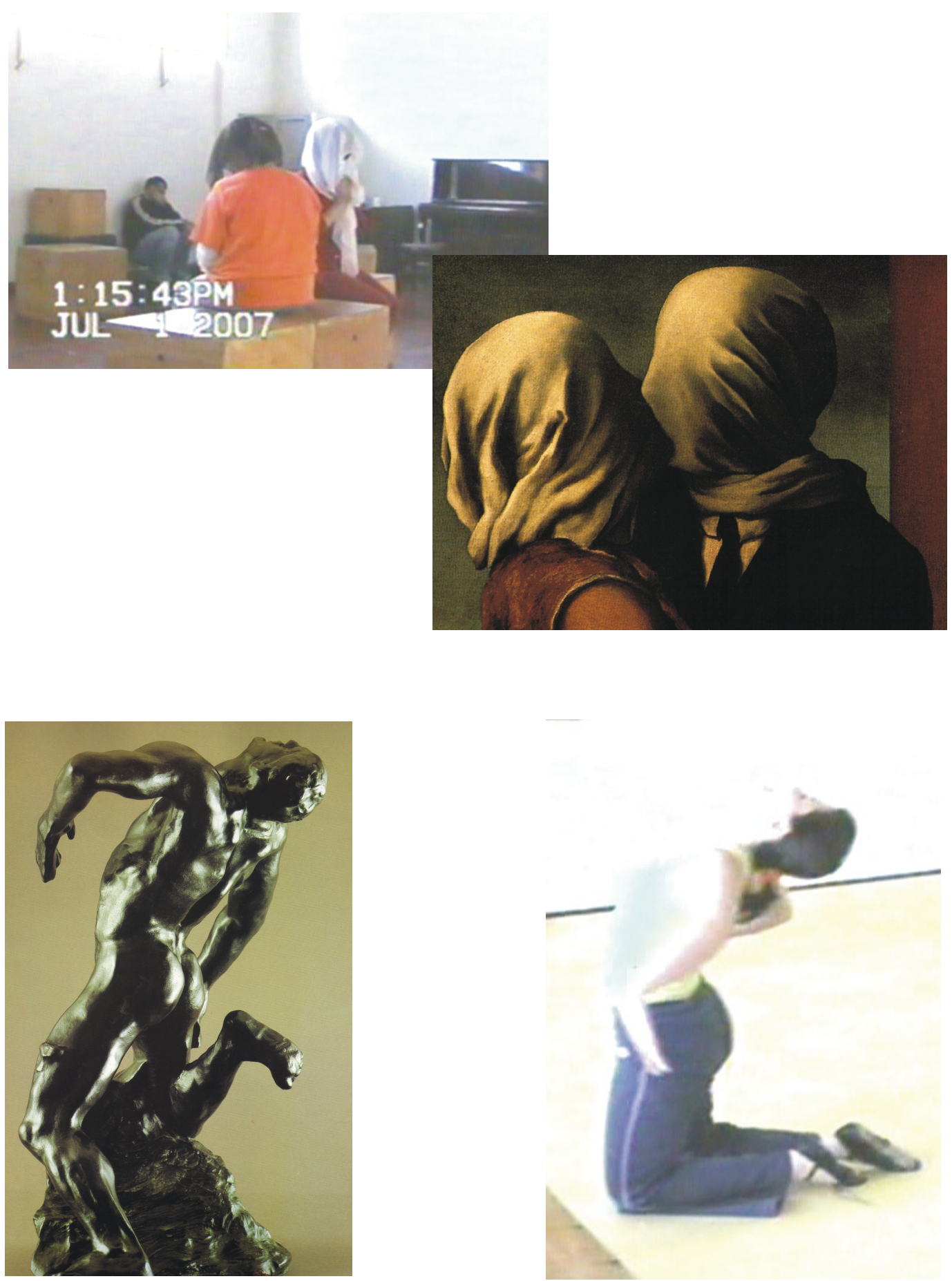

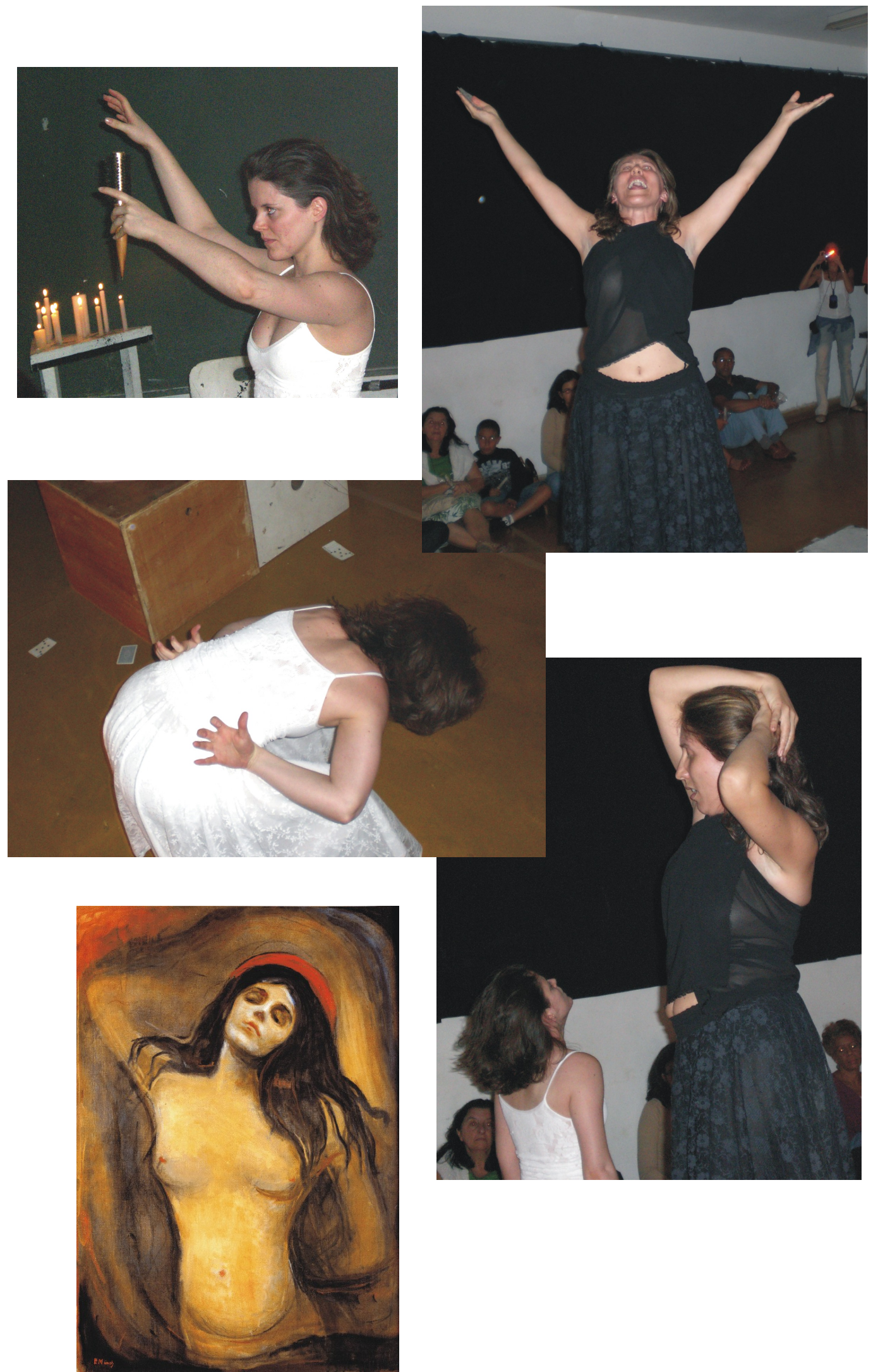